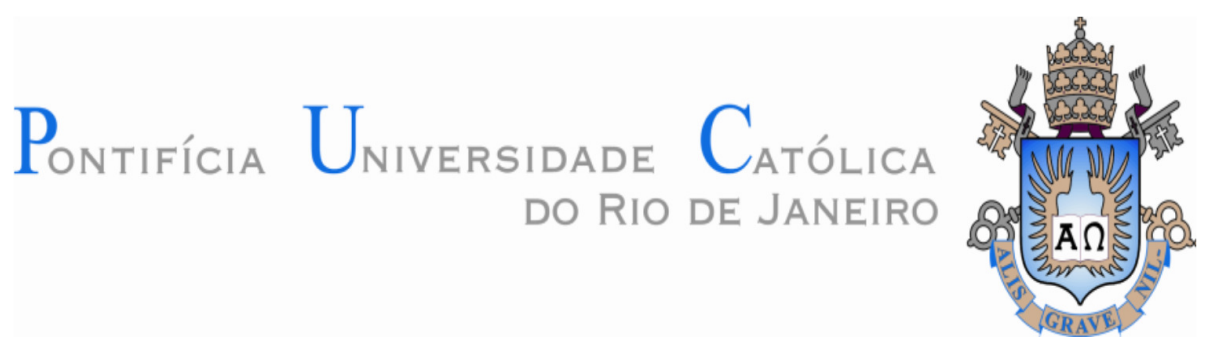

Mohandas Karamchand Oliveira de Souza

\title{
A Dúvida Cética no Quod Nihil Scitur de Francisco \\ Sanches
}

\section{Dissertação de Mestrado}

Dissertação apresentada como requisito parcial para obtenção do grau de Mestre pelo Programa de Pós-graduação em Filosofia do Departamento de Filosofia do Centro de Teologia e Ciências Humanas da PUC-Rio.

Orientador: Prof. Danilo Marcondes de Souza Filho 


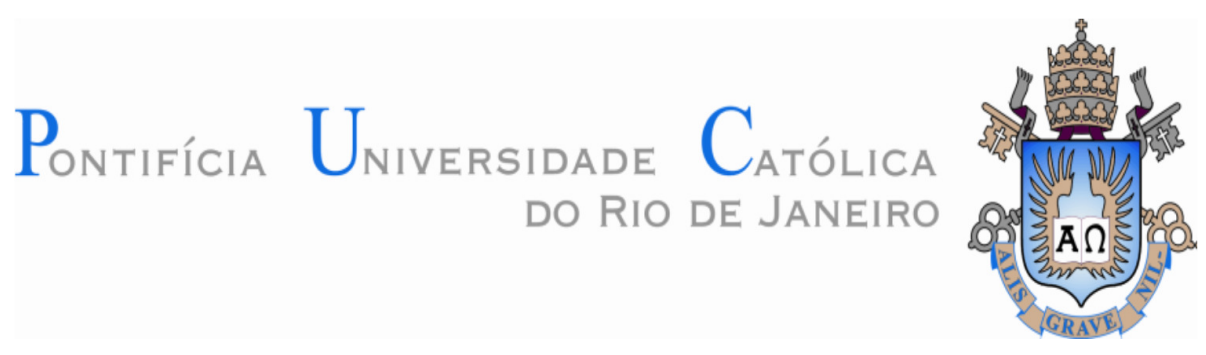

MOHANDAS KARAMCHAND O DE SOUZA

\section{"A Dúvida Cética no Quod Nihil Scitur de Francisco Sanches"}

Dissertação apresentada como requisito parcial para obtenção do grau de Mestre pelo Programa de Pós-graduação em Filosofia do Departamento de Filosofia do Centro de Teologia e Ciências Humanas da PUC-Rio. Aprovada pela Comissão Examinadora abaixo assinada.

Prof. Danilo Marcondes de Souza Filho

Orientador

Departamento de Filosofia - PUC-Rio

Prof. Rogério Soares da Costa Departamento de Filosofia - PUC -Rio

Prof. Luiz Eduardo Bicca Universidade do Estado do Rio de Janeiro - UERJ

Profa. Denise Berruezo Portinari Coordenadora Setorial do Centro de Teologia e Ciências Humanas - PUC-Rio

Rio de Janeiro, 12 de Setembro de 2014. 
Todos os direitos reservados. É proibida a reprodução total ou parcial do trabalho sem autorização do autor, do orientador e da universidade.

\section{Mohandas Karamchand Oliveira de Souza}

Graduou-se em Filosofia (Licenciatura em 2005 e Bacharelado em 2009) na Universidade do Estado do Rio de Janeiro (UERJ). Concluiu a Especialização em Filosofia Moderna e Contemporânea nesta mesma instituição em 2011. Leciona como Professor Docente I na SEEDUC desde 2007.

Ficha Catalográfica

Souza, Mohandas Karamchand Oliveira de

A dúvida cética no Quod Nihil Scitur de Francisco Sanches / Mohandas Karamchand Oliveira de Souza; orientador: Danilo Marcondes de Souza Filho. - 2014.

124 f.; $30 \mathrm{~cm}$

Dissertação (mestrado)-Pontifícia Universidade Católica do Rio de Janeiro, Departamento de Filosofia, 2014.

Inclui bibliografia

1. Filosofia - Teses. 2. Ceticismo. 3. Sanches. 4. Conhecimento. I. Souza Filho, Danilo Marcondes de. II. Pontifícia Universidade Católica do Rio de Janeiro. Departamento de Filosofia. III. Título. 
Para minha Família e Mykaelle, pelo carinho, pelo apoio e pela ajuda. Aos mestres Luiz Bicca e Danilo Marcondes, cicerones na via cética. 


\section{Agradecimentos}

À minha família, cujo ambiente foi o fundamento do caminho que me trouxe até aqui. A Mykaelle, cujo carinho e apoio foram imensuráveis.

Aos grandes mestres Luiz Bicca e Danilo Marcondes. Aquele, por ter me introduzido à via cética e pelo forte incentivo desde minha graduação. Este, pela gentileza de me aceitar como orientando e por exercer compreensiva e pacientemente tal tarefa.

Aos amigos Maria Clara Azevedo, Rafael Huguenin, Rodrigo de Brito e Rogério Costa pelo incentivo e pela presença no caminho da graduação até aqui. Ao último igualmente pela participação na banca examinadora deste trabalho.

À professora Vera Bueno, pela gentileza de aceitar avaliar meu pré-projeto e ser suplente na banca examinadora. Aos professores e membros do departamento, sempre tão solícitos e dispostos a ajudar.

Ao CNPq e à PUC-Rio, pelos auxílios concedidos, sem os quais este trabalho não poderia ter sido concebido. 


\section{Resumo}

Souza, Mohandas Karamchand Oliveira de; Marcondes, Danilo. A Dúvida Cética no Quod Nihil Scitur de Francisco Sanches. Rio de Janeiro, 2014. 124p. Dissertação de Mestrado - Departamento de Filosofia, Pontifícia Universidade Católica do Rio de Janeiro.

Apresentamos aqui o ceticismo desenvolvido por Francisco Sanches (1551 - 1623), filósofo e médico português, em sua obra Que Nada se Sabe, na qual, defendemos, é cunhada uma dúvida metódica e hiperbólica, comumente atribuída ao engenho cartesiano. Também sustentamos que Sanches desenvolve um "ceticismo construtivo ou mitigado", conforme a expressão de Richard Popkin, ao propor um conhecimento imperfeito em resposta à dúvida e por ela própria limitado. Tal conhecimento não acessa a natureza das coisas, se mantém na esfera secundária e falha da interação entre as imagens sensíveis que recebemos da realidade e a análise destas por parte do juízo. Acreditamos poder, com tais informações, avaliar Sanches como importante figura na formação do ceticismo da Modernidade.

\section{Palavras-chave}

Ceticismo; Sanches; Conhecimento. 


\section{Abstract}

Souza, Mohandas Karamchand Oliveira de; Marcondes, Danilo (Advisor). The Sceptical Doubt in Francisco Sanches's Quod Nihil Scitur. Rio de Janeiro, 2014. 124p. MSc. Dissertation - Departamento de Filosofia, Pontifícia Universidade Católica do Rio de Janeiro.

Here we present the scepticism developed by Francisco Sanches (1551 1623), portuguese philosopher and physician, in his work That Nothing is Known, in wich, we say, the methodological and hyperbolical doubt, often attributed to the Cartesian enterprise, is forged. We also say that Sanches sustains a "mitigated or constructive scepticism", after the expression of Richard Popkin, when he proposes imperfect knowledge as an answer to doubt, and by it limited. Such Knowledge doesn't access the nature of things, keeps itself in the secondary plan of the flawed interaction between the sensible images that we receive from reality and its analysis by judgment. With such information, we believe, we'll be able to evaluate Sanches as an important figure in the forging of the scepticism of Modern Age.

\section{Keywords}

Scepticism; Sanches; Knowledge. 


\section{Sumário}

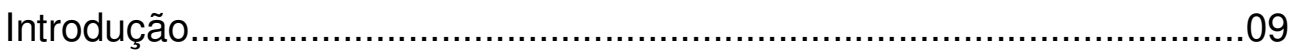

Cap I - Ceticismo Antigo.........................................................................11

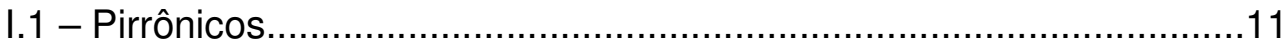

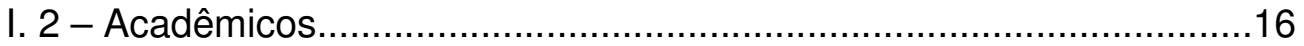

Cap II - A transmissão e o impacto da retomada do ceticismo antigo.....26

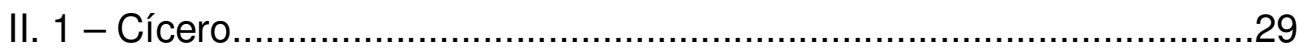

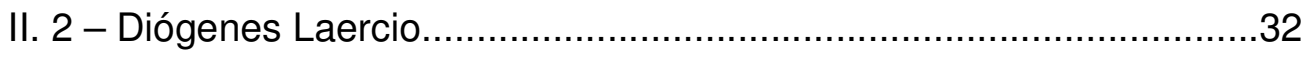

III. 3 - Sexto Empírico.......................................................................3

Cap. III - Vida e obra de Sanches............................................................

Cap IV - O objetivo polêmico do Quod Nihil Scitur.................................47

Cap V - Críticas à ciência.....................................................................68

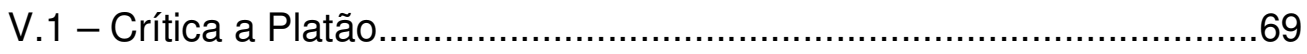

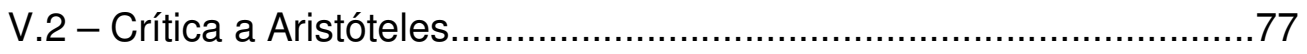

V.3 - O conhecimento perfeito do assunto.............................................90

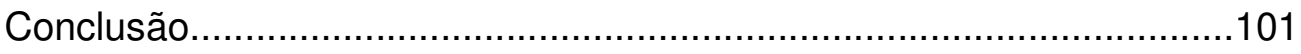

Referências bibliográficas................................................................115 


\section{Introdução}

O pensamento filosófico da Modernidade instaurou-se após o Renascimento, período transitório de renovação e duras críticas à tradição filosófica da Idade Média. Neste momento de grande efervescência cultural acontece a retomada do ceticismo antigo, tendência filosófica atualmente aceita quase como consenso pelos historiadores da filosofia como determinante para a formulação da modernidade filosófica. Costuma-se também atribuir a René Descartes a autoria do ímpeto filosófico moderno, caracterizado sobretudo pelo exercício deliberado e hiperbólico da dúvida cética.

Por nossa parte, pensamos ser possível recuar algumas décadas e atribuir a dúvida característica da Modernidade a outra personalidade: Francisco Sanches. Este homem, filósofo e médico português, cronologicamente inserido no Renascimento desenvolveu, em sua obra Que Nada se Sabe, um ceticismo tão extremo quanto o antigo. Interessa-nos aqui apresentar este tipo moderno do ceticismo.

Iniciaremos nossa tarefa com a exposição das matrizes do ceticismo antigo, o ceticismo pirrônico e o acadêmico, com vistas à determinação, de um modo geral, daquilo que entendemos por ceticismo e à constatação posterior da pertinência do pensamento de Sanches à veia cética. No entanto, não pretendemos fazer um estudo comparativo exaustivo entre as correntes céticas antigas e a concepção sanchesiana de ceticismo. Apresentaremos em seguida algumas diferenças entre o ceticismo antigo e o moderno, tal qual apontadas pelos comentadores, sem recorrer ao estudo sistemático dos filósofos modernos, dada a imensidão de possíveis ceticismos modernos conforme se analisa a obra dos diversos pensadores modernos de relevo.

Então apresentaremos algumas informações acerca da retomada, feita na Modernidade, dos escritos céticos da Antiguidade, tanto os pirrônicos quanto os acadêmicos, na medida em que isto nos ajude a perceber a influência destas correntes na formação do pensamento moderno.

Em seguida, cuidaremos de seguir os caminhos da dúvida tal qual desenvolvida no escrito supracitado do filósofo português. A dúvida aparecerá aplicada à tradição do pensamento filosófico, com ênfase em Platão e na tradição lógico-dialética aristotélica. Culminando com o ataque feito por Sanches à noção 
de ciência, tão essencialista quanto as precedentes, formulada por ele mesmo como prova de que a dúvida não pode ser ultrapassada absolutamente. Então, partiremos à apresentação da solução paliativa de Sanches para nossa condição de limitação à imprecisão do conhecimento, que foi nomeada por Richard Popkin pelo conceito de Ceticismo Mitigado. 


\section{CAP. I - Ceticismo Antigo}

É antiga a questão acerca do que diferencia a tendência pirrônica da tendência acadêmica do ceticismo grego, pois ambas se dizem aporéticas, por não conseguirem decidir sobre a verdade frente aos conflitos durante investigações, e suspensivas, por suspenderem o juízo frente às aporias apresentadas por qualquer pesquisa. Mas o seriam mesmo? Também são antigas as acusações de contrassenso e impossibilidade prática de se viver o ceticismo (apraxia). A persistência de tal questão é válida, pois não se dá necessariamente pela falta de fontes, mas sim a partir da interpretação das fontes que nos restaram de ambas correntes. Apresentaremos as linhas mais gerais destas duas correntes filosóficas com o intuito de responder às questões postas.

\section{1 - Pirrônicos}

Os pirrônicos assim denominam-se por dizerem retomar o pensamento de Pirro de Élis (Séc. IV a. C.). Sabemos dos seguintes céticos pirrônicos: Timão de Flionte, que foi discípulo de Pirro, Enesidemo, Agripa e Sexto Empírico. Este último, tendo vivido por volta do Século II da era cristã, é a nossa fonte mais completa do ceticismo antigo. Dele nos restaram as Hipotiposes Pirrônicas e uma série de onze livros chamada Adversus Mathematicos. A primeira obra é uma fonte privilegiada para conhecermos uma apresentação das bases do pensamento cético antigo. A segunda é a aplicação da postura cética a determinadas ciências.

O primeiro livro das Hipotiposes se ocupa sobretudo da definição do ceticismo. Esta delimitação se faz inicialmente através da distinção entre o ceticismo e o dogmatismo. Sexto diz que os possíveis resultados das investigações sobre qualquer assunto, incluindo a investigação filosófica, são: 1) a afirmação da descoberta da resposta ou da verdade; 2) a negação da descoberta e a afirmação da inapreensibilidade da resposta ou da verdade; 3) a continuidade da investigação. Ainda conforme Sexto, os primeiros são propriamente denominados dogmáticos, pois acreditam possuir um conhecimento verdadeiro. Os segundos, os céticos 
acadêmicos Clitômacus e Carnéades, são de certa forma dogmáticos negativos, pois afirmam ser impossível descobrir um conhecimento verdadeiro. Os terceiros são os céticos pirrônicos, pois não encontram um conhecimento verdadeiro e não afirmam incisivamente sua inviabilidade perpétua, mas simplesmente relatam ser esta a forma como as coisas lhes aparecem neste momento, de modo que persiste a possibilidade de continuidade da investigação.

Em seguida Sexto caracteriza o ceticismo que defende como: 1) Investigativo, pois é inquiridor; 2) Suspensivo, por causa do sentimento suscitado no inquiridor após a investigação; 3) Aporético, pois problematiza tudo a ponto de não poder nem assentir nem negar nada; 4) Pirrônico, pois Pirro parece ter sido o primeiro a adotar sistematicamente o ceticismo como forma de vida. Então Sexto define:

Ceticismo é uma habilidade para dispor oposições, de qualquer maneira, entre coisas que aparecem e que são pensadas, é uma habilidade através da qual devido à equipolência nos objetos e concepções opostas, nós chegamos primeiramente à suspensão do juízo e posteriormente à tranquilidade. ${ }^{1}$

Por "habilidade", Sexto entende pura e simplesmente o "estar capacitado a'. Por "coisas que aparecem", entende-se neste contexto os objetos da percepção. Por "de qualquer maneira", Sexto entende as variadas combinações de oposições que se pode fazer entre o que aparece e o que é pensado, isto é, o que aparece ao que aparece, o que é pensado ao que é pensado, o que aparece ao que é pensado e o que é pensado ao que aparece. Por “concepções opostas", Sexto entende relatos conflitantes, não necessariamente afirmativos e negativos. Por "equipolência", Sexto entende a igualdade de persuasão entre os relatos conflitantes de maneira que nenhum prevaleça sobre o outro. Por "tranquilidade", Sexto entende a liberação das perturbações e a quietude da alma.

O mote do ceticismo é a possibilidade de atingir a tranquilidade, pois como Sexto indica "os céticos dizem que o princípio causal do ceticismo é a esperança de tornar-se tranquilo" ${ }^{2}$. Porém, diferentemente dos dogmáticos, os céticos não esperam atingi-la através do estabelecimento de verdades, mas sim por meio da suspensão dos juízos. Pois os céticos aceitam que para cada concepção há

${ }^{1}$ EMPIRICUS, S., Outlines of Scepticism, p. 4. Também citaremos as Hipotiposes Pirrônicas através da abreviação $H P$, seguida do Livro e do parágrafo para que o leitor possa facilmente se guiar ao consultar outras edições desta obra. $H P$, I, 8. Tradução nossa.

${ }^{2}$ Ibid., pp. 5-6. HP, I, 12. Tradução nossa. 
uma concepção oposta conflitante e equipolente, o que impossibilita tanto a decisão sobre a qual delas assentir, quanto o encerramento da inquietação causada pela investigação.

Aparentemente segue-se do que foi dito que os pirrônicos não sustentam nenhuma crença. Será assim? Na verdade, não. Sexto Empírico diz que, diferentemente de como o faz aquilo que costuma ser entendido como 'crença', os céticos não dão assentimento a objetos de investigação obscuros. Além disso, quem diz ter crenças assegura a existência real daquilo que crê. Divergentemente, diz Sexto, os céticos pirrônicos nem dão assentimento ao que é obscuro, nem asseguram a existência real daquilo que creem. Os céticos dão assentimento involuntário aos sentimentos injetados neles pelas aparências. No entanto, o fenômeno, aquilo que aparece aos céticos, não é assegurado por estes como realmente existente na natureza. Diferentemente dos dogmáticos, os céticos nem problematizam, nem tentam revelar a natureza das coisas. Eles relatam como as coisas lhes aparecem, sem a pretensão de abarcarem com seu discurso a natureza última daquilo ao qual se referem. É digna de nossa atenção a seguinte passagem de Sexto:

Como dissemos anteriormente, não recusamos qualquer coisa que nos conduza, sem o nosso desejo, a assentir em concordância com uma aparência passiva - e estas coisas são precisamente o que é aparente. Quando investigamos se as coisas existentes são da maneira como elas aparecem, nós garantimos que elas aparecem e o que nós investigamos não é aquilo que é aparente, mas sim o que se diz sobre aquilo que é aparente - e isto é diferente de investigar aquilo que é aparente em si mesmo. $^{3}$

Fica claro que os céticos não investigam os fenômenos e suas aparências, mas sim o que se diz de suas aparências. Também se torna evidente que os céticos adotam o fenômeno como critério de ação, isto é, aquilo que aparece e lhes leva passivamente ao assentimento. Isto parece livrar os céticos pirrônicos da crítica da apraxia. E tomando o fenômeno como critério de ação, os céticos vivem de acordo com as observâncias da vida comum e adoxasticamente, isto é, sem ter opiniões sobre a natureza daquilo que lhes aparece. Deste modo, o cético preserva sua atitude característica teórica e existencialmente. Outra passagem de suma importância é a seguinte:

\footnotetext{
${ }^{3}$ Ibid., p. 8. HP, I, 19. Tradução nossa.
} 
Estas observâncias diárias parecem ter quarto partes e consistir na direção da natureza, na necessidade de nossas afecções, na tradição das leis e dos costumes, e no aprendizado dos tipos de artes. Pela direção da natureza nós somos naturalmente capazes da percepção e do pensar. Pela necessidade das afecções, a fome nos conduz ao alimento e a sede à bebida. Pela tradição dos costumes e das leis, nós aceitamos, do ponto de vista do cotidiano, que a piedade é boa e que a impiedade é má. Pelo aprendizado dos tipos de artes, nós não nos mantemos inativos naqueles tipos que aceitamos. 4

Aqui entendermos como o cético pirrônico pode responder a todas as acusações de impossibilidade de viver de acordo com sua postura cética. Se, por um lado, vemos na abordagem dos dogmáticos uma tentativa de desvelar e mostrar detalhadamente a essência da realidade, afastando-nos da mesma. Por outro lado, Sexto propõe uma volta do homem à vida comum. Não devemos buscar dogmaticamente responder a questões que não podem ser respondidas, pois estão além de nossa capacidade. A investigação dogmática causa inquietude. A tranquilidade segue fortuitamente a extinção de nossa investigação. Segundo a proposta cética pirrônica não é a razão quem vai nos guiar na vida, mas sim os instintos naturais e os costumes, dado que, assim nos parece, a razão que guia a investigação cética só é capaz de perceber aporias.

Surge o elemento filantrópico-terapêutico da investigação pirrônica, declarado por Sexto Empírico ao final das Hipotiposes Pirrônicas:

Os Céticos são filantrópicos e desejam curar através de argumentos, até onde eles possam, a presunção e a precipitação dos dogmáticos. Assim como os médicos possuem remédios para as aflições corporais que diferem em potência, e aplicam remédios severos para pacientes severamente adoentados e remédios mais brandos para aqueles levemente adoentados, então os céticos apresentam argumentos que diferem em força. ${ }^{5}$

A disposição dialética de argumentos conflitantes cria o seguinte itinerário: conflito de teorias (diaphonia) - equipolência das teorias conflitantes (isosthenia) - impasse (aporia) - suspensão dos juízos (epoché) - tranquilidade (ataraxia). O caminho traçado pelo método pirrônico até o abandono do dogmatismo é proposital e se dirige ao objetivo da cura das aflições causadas pela vã busca dogmática da verdade. Lembremos que Sexto Empírico escolheu a medicina como arte e atividade prática. Deste modo, a autonegação gerada pelas proposições céticas é análoga à ação de um purgante:

\footnotetext{
${ }^{4}$ Ibid., p. 9. HP, I, 23-24. Tradução nossa.

${ }^{5}$ Ibid., p. 216. HP, III, 280. Tradução nossa.
} 
No caso das proposições céticas, deve-se entender que nós não afirmamos definitivamente que elas são verdadeiras - afinal, dizemos que elas podem ser destruídas por si mesmas, sendo canceladas conjuntamente com aquilo ao qual se aplicam, assim como drogas purgativas não drenam meramente os humores do corpo, mas também se dirigem para fora conjuntamente com os humores. ${ }^{6}$

No intuito de exercer a cura das aflições do dogmático os céticos reuniram e desenvolveram uma longa série de argumentos que se apresentam sobre a forma de Modos. Estes estão dispostos nos 10 Modos de Enesidemo (HP, I, 35 - 163) e nos 5 Modos de Agripa (HP, I, 164 - 177). Sexto Diz que este número é impreciso, mas a apresentação dos modos se faz necessária para o melhor entendimento das oposições pelas quais se define a investigação pirrônica.

Segundo a ordem apresentada por Sexto Empírico, os 10 Modos de Enesidemo são: primeiro, o Modo que explora as variações entre a constituição corpórea dos diferentes animais; segundo, o Modo que explora as diferenças entre os humanos; terceiro, o Modo que considera as diferentes constituições dos órgãos dos sentidos; quarto, o Modo que condiciona a partir das circunstâncias; quinto, o Modo que depende de intervalos, posições e lugares; sexto, o Modo que considera a mistura de substâncias; sétimo, o Modo que aponta a dependência de quantidades e preparo das coisas existentes; oitavo, o Modo que deriva da relatividade; nono, o Modo que depende da frequência ou raridade dos acontecimentos; décimo, o Modo que depende dos costumes das leis e da crença em mitos e suposições dogmáticas.

Sexto Empírico ressalta que estes Modos podem ser subsumidos em três grupos: aqueles que derivam do sujeito que julga; aquele que deriva do objeto julgado; aquele que combina ambos. Os quatro primeiros Modos enquadram-se no grupo voltado para o sujeito que julga, pois quem julga é um humano, um animal ou um sentido e sempre em uma circunstância. O grupo da argumentação voltada para o objeto julgado é composto pelo sétimo e pelo décimo Modos. O grupo voltado para os modos que combinam argumentação sobre o sujeito que julga e o objeto julgado é constituído pelo quinto, sexto, oitavo e nono Modos.

Com ênfase numa argumentação formal e mais geral, e também visando a suspensão dos juízos, os 5 Modos de Agripa são: primeiro, o Modo da disputa indecidível, que se dá na vida ordinária e entre os filósofos, sempre ocasionando a

\footnotetext{
${ }^{6}$ Ibid., p. 52. HP, I, 206. Tradução nossa.
} 
suspensão dos juízos; segundo, o Modo da regressão ao infinito, segundo o qual cada convicção que apresentamos precisa de uma justificativa, que por sua vez também precisa de justificativa e assim infinitamente numa cadeia regressiva de causalidade interminável; terceiro, o Modo da relatividade no qual se estabelece que o objeto julgado parece relativo ao sujeito que o julga e às condições nas quais tal julgamento é feito; quarto, o Modo da hipótese, que aponta a postulação injustificada de algo pelos dogmáticos quando eles tentam fugir da regressão ao infinito; quinto, o Modo da reciprocidade, onde um circulo vicioso faz com que o que deve ser confirmar um objeto investigado passa a ser confirmado por este mesmo objeto em investigação.

\section{2 - Acadêmicos}

A Academia de Platão teve durante os Séculos II e I a.C. uma guinada cética. Como já vimos, Sexto Empírico classifica a abordagem dos acadêmicos como um dogmatismo negativo. Tal não é a avaliação de Cícero, representante do ceticismo acadêmico e a mais confiada fonte que nos restou sobre o ceticismo da academia. A abordagem cética da Academia não é linear, há acréscimos e algumas divergências. Cícero parece aderir à abordagem mais próxima do pensamento do que ele chama de a Nova Academia de Arcesilau (316 - 241 A.c.) e Carnéades (214 - 129 A.c.). Nossa principal fonte sobre o ceticismo acadêmico é o que restou do diálogo Academica, de Cícero. Há ainda outras fontes, como as Hipotiposes Pirrônicas e Adversus Mathematicos de Sexto Empírico e as Vidas e Doutrinas dos Filósofos Ilustres de Diógenes Laercio.

Conforme Cícero, os céticos acadêmicos seguem a prática de opor-se a todas as posições, postura que seria seu método de investigação e sua maneira de posicionar-se contra toda autoridade possível. A busca contínua, consciente e entusiástica dos céticos não tem outra finalidade além da aproximação a uma formulação da verdade. Tal concepção se dá através de elementos plausíveis, ou persuasivos, aos quais se adere fragilmente, sem concebê-los como verdades, diferentemente dos filósofos dogmáticos, que julgam precipitadamente sem a devida capacitação ou com base em preconceitos advindos de sua formação e não 
a partir de uma análise cuidadosa, guiada pela razão e livre da submissão a alguma autoridade. Permita-se aqui uma longa citação, dado que nela encontramos elementos textuais comprovadores de todos estes elementos delineadores do ceticismo acadêmico:

(...) é nossa prática dizer o que pensamos contra todas as posições. (...) porque queremos descobrir a verdade (...) e nós a procuramos consciente e entusiasticamente. (...) o conhecimento sempre está cercado com dificuldades e com as obscuridades das coisas mesmas, e a fraqueza de nosso julgamento (...) Ainda assim, (...) nós não vamos abandonar nosso entusiasmo pela investigação devido à exaustão. Nem possuem nossos argumentos outro propósito que não seja delinear ou formular a verdade ou sua maior aproximação possível através da argumentação sobre ambos os lados.

A única diferença entre nós e os filósofos que acreditam possuir conhecimento é que eles não duvidam da verdade dos pontos de vista que defendem, enquanto nós sustentamos muitos pontos de vista como sendo persuasivos, isto é, que nós podemos seguir prontamente, mas dificilmente podemos afirmar. Mas somos mais livres e menos coagidos, pois nossa capacidade de julgamento permanece intacta e nós não somos forçados por nenhuma obrigação a defender um conjunto de visões prescritas e praticamente impostas a nós por alguém. Outros filósofos, afinal, trabalham sob duas restrições. Primeiramente, estão acorrentados a um ponto por elos formados antes que fossem aptos para julgar o que é melhor. Em segundo lugar, eles julgam assuntos sobre os quais nada sabem, sob a pressão de um amigo ou cativados por um único discurso de alguém que eles viram pela primeira vez. ${ }^{7}$

Em linhas gerais, frente ao dogmatismo estoico, objeto dos ataques destes céticos, os acadêmicos declaravam a inapreensibilidade universal, isto é, a nossa incapacidade de apreender a natureza objetiva da realidade. Por esta razão, os céticos da Academia também foram questionados acerca da coerência e da possibilidade de se viver uma vida seguindo os parâmetros céticos. Como método de investigação, os acadêmicos procediam pela argumentação sobre ambas as partes, ou seja, sustentando que duas ou mais teses contraditórias são igualmente fortes ou fracas. As consequências de tais posturas são a suspensão de nossos pronunciamentos sobre a realidade objetiva e a necessidade de se conceber uma nova forma de decidir por aquilo que aceitamos ou não, já que não se pode ter certeza no sentido tradicional, o dogmático. A suspensão dos juízos e o advento de um critério que não se impõe como absoluto são tarefas também realizadas pelos pirrônicos, porém de forma diferente. É o que se perceberá ao

\footnotetext{
${ }^{7}$ CICERO, M. T., On Academic Scepticism, p. 6. Também citaremos o Academica através da abreviatura $A c$ seguida do Livro e dos parágrafos para que o leitor possa facilmente se guiar ao consultar outras edições desta obra. Ac, II, 7-8. Tradução nossa.
} 
apresentarmos o pensamento de Arcesilau e de Carnéades, nos quais Cícero se apoia para defender o ceticismo da Academia.

Como também acontece com o pirronismo, há divergência acerca da origem das noções céticas nos acadêmicos. Assim, divergem os comentadores desde a antiguidade acerca, por exemplo, dos seguintes problemas: teria Arcesilau adquirido a noção de suspensão de Pirro (a quem conheceu e frequentou, pois este não teria conceituado, mas sim vivido a suspensão dos juízos)? Diferentemente, também defende-se que a suspensão seria um aquisição de Arcesilau feita a partir do corpo teórico estoico do pensamento de Zenão. Argumento negado por Cícero em Ac, II, 77, onde Arcesilau é descrito como o autor da ideia da epoché. A questão sobre a origem de cada conceito não é parte do cerne deste trabalho. Dado que assim desviamo-nos de uma observação dos traços fortes das correntes céticas antigas, e neste momento, especificamente, da corrente acadêmica, tais quais apresentados por Cícero.

Os ensinamentos de Platão não eram mais discutidos, mas somente comentados, como se a verdade já houvesse sido descoberta. Após sucessivas direções que visaram o estabelecimento de uma doutrina platônica canônica, apropriadamente para o seu ensino, Arcesilau apontou a necessidade da retomada da investigação aberta da verdade, tal qual havia sido ensinada por Sócrates. Semelhantemente a este filósofo, Arcesilau não escreveu nada. Em $A c$, II, 76 e $A c$, I, 44, Cícero afirma que Arcesilau, a quem se atribui a guinada cética da academia, debateu com o estoico Zenão não por um criticismo vaidoso ou um puro espírito de rivalidade, mas sim por buscar a verdade e por causa da obscuridade das coisas que anteriormente tinha levado o mestre de Platão à confissão da própria ignorância. Em $A c$, I, 45, Cícero atribui ao patrono do ceticismo acadêmico as práticas de argumentar contra todas as posições de todos os outros, em busca de equipolência e da suspensão como forma de evitarmos a precipitação e o erro em nossos assentimentos devido à profunda inapreensibilidade das coisas. Tal descrição apresenta um ceticismo tão extremo quanto o pirrônico, pois Cícero diz que nem mesmo o reconhecimento socrático da própria ignorância tinha o assentimento de Arcesilau.

Zenão desenvolveu uma teoria do conhecimento inovadora, que fornecia um caminho para o tipo de sabedoria buscado por Sócrates e seus seguidores. Em Ac, I, 40 - 42, consta que primeiramente Zenão atribuiu a formação das crenças à 
nossa capacidade voluntária de assentir às nossas impressões (phantasia) sobre algo; então, Zenão estabelece que algumas de nossas impressões são apreensíveis, ou 'catalépticas', (phantasia katalêptikê), isto é, são auto suficientes e assentir a elas nos leva à apreensão do objeto, garantida pela nossa percepção; em seguida, o fundador do Pórtico, argumenta que devemos restringir nosso assentimento às impressões apreensivas, do contrário, seremos irracionais e teremos somente opiniões (doxa) ao invés do conhecimento objetivo, estável e confiável. A impressão apreensiva é definida pelas seguintes características: a) origina-se a partir daquilo que é; b) é impressa de acordo com aquilo que é; c) e não poderia originar-se a partir daquilo que não é.

Zenão identifica seu critério da verdade nas impressões apreensivas e compara as possibilidades de conhecimento aos seguintes gestos: ao estender sua mão direita espalmada diante de si, Zenão dizia ser essa uma impressão; em seguida, contraía ligeiramente os dedos e afirmava que assim tínhamos o assentimento; depois, ao cerrar mais ainda os dedos e formar um punho, com a mão ligeiramente fechada ele dizia que assim é a apreensão; e finalmente ao por a mão esquerda, apertando o punho cerrado formado pela outra mão, tínhamos o conhecimento científico, privilégio do sábio. (Ac, II, 38 e 145). O papel do sábio é não dar assentimento a impressões que não sejam apreensivas, sob pena de descaracterizar sua sabedoria.

Em Contra os Lógicos $^{8}$, Sexto Empírico apresenta um ataque de Arcesilau à impressão apreensiva quando relata o argumento de que não se assente às impressões, mas sim ao discurso sobre elas, isto é, a nossos juízos. E em seguida, continua atacando mais duramente, ao ressaltar que, conforme vários possíveis exemplos, não há impressão real que não possa parecer ser falsa.

Este segundo ataque encontra-se melhor explicado em $A c$, II, 77-78, que o apresenta como o estabelecimento da impossibilidade de se garantir o cumprimento da condição c), acima apresentada como requisito de uma impressão apreensiva. Na passagem em questão Cícero reproduz um possível diálogo entre Arcesilau e Zenão. Nem Zenão, nem algum de seus discípulos formulou a necessidade da suspensão dos juízos, diz Cícero, enquanto Arcesilau não só a

${ }^{8}$ EMPIRICUS, S., Against the Logicians, p. 33. Os Livros VII e VII de Adversus Mathematicos são conhecidos como Contra os Lógicos. Citarei esta obra pela abreviatura $A M$, seguida do Livro e do parágrafo para que o leitor possa facilmente se guiar ao consultar outras edições desta. $A M$, VII, 154. 
concebeu como verdadeira, honrosa e também como necessária para o sábio. Arcesilau pergunta a Zenão o que aconteceria se o sábio não pudesse apreender nada e não pudesse ter meras opiniões. O estoico, por sua vez, responde que isso não acontece, pois há o que se apreender: as impressões apreensivas, que se originam de acordo com as condições a) e b). O acadêmico então retruca com a possibilidade de uma impressão verdadeira parecer-se com uma falsa. Zenão percebe que se alguma impressão verdadeira fosse parecida com alguma falsa, isto é, uma impressão que vem daquilo que é se assemelhasse a uma impressão que parte daquilo que não é, então nada poderia ser apreendido. Isto foi incorporado à argumentação chave de Arcesilau que propõe a inapreensibilidade:

1) algumas impressões são verdadeiras, outras falsas; 2) uma impressão falsa não é apreensível; 3) toda impressão verdadeira é tal que pode-se ter uma impressão falsa como ela; 4)quando duas impressões são indiscerníveis, é impossível que uma delas seja apreensível e a outra não o seja; 5) logo, nenhuma impressão é apreensível. ${ }^{9}$

Continuando a sequência lógica desta argumentação concluímos que se não há impressões apreensivas e é irracional dar assentimento a impressões não apreensivas, então não se deve dar assentimento a nenhuma impressão e o papel do sábio é suspender o juízo. Arcesilau veiculava a inapreensibilidade com o intuito de mostrar que se há uma sabedoria, ela consiste na suspensão do juízo. Ele praticava a defesa dialética de tese e antítese com o intuito de estabelecer a isosthenia e a suspensão do juízo acerca de ambas. Sedley ${ }^{10}$ indica Arcesilau como o primeiro a usar a equipolência como antídoto para a crença. Sexto Empírico, em HP, I, 232, atribui ao ceticismo de Arcesilau a busca pela suspensão, além de ainda aproximar este acadêmico às convicções pirrônicas por ele não ser assertivo em relação à realidade ou irrealidade das coisas, por não escolher a partir de preferências por persuasão ou falta desta, tal qual Carnéades o faz, e por suspender o juízo.

A crítica estoica da apraxia é desenvolvida com base na argumentação de que a ação depende de nosso assentimento e uma vez que Arcesilau propunha a suspensão deste, então não poderia nunca decidir como agir. Arcesilau recorre à noção do razoável (eulogon) como solução. Há dois relatos sobre a resposta de

\footnotetext{
${ }^{9}$ CICERO, M. T., On Academic Scepticism, p. 25. Ac, II, 40. Tradução nossa.

${ }^{10}$ SEDLEY, D., The Motivation of Greek Skepticism, p. 11.
} 
Arcesilau ao problema da apraxia. Um vindo de Plutarco, Adversus Colotem 1122-d, e o outro vindo de Sexto Empírico, AM, VII, 158.

No relato de Plutarco, o epicurista Colotes questiona Arcesilau acerca da impossibilidade de agir ao se defender a suspensão dos juízos. A resposta de Arcesilau se dá de seguinte maneira, conforme Plutarco:

A alma tem três movimentos: sensação, impulso e assentimento. A sensação não pode ser eliminada, mesmo que quiséssemos: ao invés, ao encontrarmos um objeto, recebemos necessariamente uma impressão e somos afetados. O impulso, ocasionado pela sensação, nos move na forma da ação para um objetivo adequado (...)

Assim, aqueles que suspendem o julgamento sobre tudo também não eliminam o segundo movimento, mas seguem seu impulso, que os leva naturalmente para as coisas que parecem adequadas.

Qual é, então, a única coisa que eles evitam? Somente aquela na qual a falsidade e o erro podem surgir, isto é, formar uma opinião e, assim, precipitar o assentimento.

$\mathrm{O}$ argumento de Arcesilau opera claramente a dissociação entre ação e assentimento, ligação que era pressuposta pelos estoicos. Veremos que Carnéades também utiliza este artifício, mas vai além. Essa resposta deixa em aberto, por exemplo, o que seria e como julgaríamos o bem e o mal. A falta de informações nas fontes nos limita. $\mathrm{O}$ que podemos conjecturar é que, como debatia na forma de argumentação ad hominem, a noção estoica do razoável foi utilizada por Arcesilau para demonstrar como, mesmo a partir das noções do sistema estoico, deveríamos suspender o juízo.

No relato de Sexto Empírico, após ter argumentado a favor da suspensão dos juízos por parte do sábio, Arcesilau oferece um critério para a conduta da vida:

Aquele que suspende o juízo sobre tudo regula suas escolhas, suas esquivas e suas ações em geral através do razoável, e por proceder de acordo com este critério ele agirá corretamente. Pois a felicidade surge através do discernimento, e o discernimento está nas ações corretas, e a ação correta é aquela que, quando executada, tem uma justificação razoável. Portanto, a pessoa que é atenta ao razoável agirá corretamente e será feliz. ${ }^{12}$

11 PLUTARCO Apud. STRIKER, G., Academics versus Pyrrhonists, reconsidered, p. 198. Tradução nossa.

${ }^{12}$ EMPIRICUS, S., Against the Logicians, p. 34. AM, VII, 158. Tradução nossa. 
Há de se notar que estes relatos, introduzem a razão entre os impulsos e a ação, e diferentemente do primeiro, no segundo relato o assentimento parece estar implícito, no ato de regular as escolhas. Visivelmente, a noção de fenômeno dos pirrônicos difere do conceito de razoável de Arcesilau. Caso houvesse alguma semelhança poderíamos dizer que Arcesilau não teria raciocínios, mas convicções irrefletidas e passivamente adquiridas na base desta regulagem das escolhas. Parece que novamente nos resta a hipótese de interpretação na qual Arcesilau seria um argumentador ad hominem afetado pelas noções combatidas. Como veremos, Carnéades claramente introduz raciocínios nos julgamentos, mas de um tipo não dogmático, possibilitado por sua distinção entre os tipos de assentimento.

Carnéades retoma a tarefa de responder à crítica da apraxia, mantendo afastado o assentimento dogmático. Tanto Sexto Empírico, quanto Cícero atribuem a Carnéades a expansão da crítica cética através da continuidade dada ao desenvolvimento da argumentação de Arcesilau. O relato da interpretação feita por Clitômaco, discípulo de Carnéades, acerca do pensamento deste mesmo filósofo, constitui talvez o ponto central do texto de Cícero. Aqui também está contido um ceticismo radical e não um dogmatismo negativo, conforme a acusação de Sexto Empírico no inicio das Hipotiposes Pirrônicas.

$\mathrm{O}$ argumento de Carnéades consiste em distinguir, primeiramente, os tipos de impressões e, em seguida, os tipos de assentimento:

A posição de Carnéades é a de que há duas categorias de impressões: a primeira, subdividida pelo princípio de que algumas impressões são apreensíveis e outras não o são; a segunda, sob o princípio de que algumas impressões são persuasivas e outras não o são. ${ }^{13}$

O sábio suspende o assentimento em dois sentidos: em um sentido, quando significa que ele não assentirá a nada mesmo; em outro sentido, quando significa que ele evitará até dar respostas mostrando que ele aprova ou desaprova algo, de maneira que ele não dirá nem "sim" nem "nada" para coisa alguma. ${ }^{14}$

Os argumentos dos céticos acadêmicos contra a apreensão com base na percepção, seja sensorial ou mental, (Ac, II, 79-90) e contra a racionalidade ( $A c$, II, 91-98), sustentam a inaprensibilidade das impressões, mas não devem ser dirigidos contra a segunda categoria de impressões. Isto se dá porque muitas percepções parecem merecer nossa aprovação, contanto que não esqueçamos que

\footnotetext{
${ }^{13}$ CICERO, M. T., On Academic Scepticism, p. 58. Ac, II, 99. Tradução nossa.

${ }^{14}$ Ibid., pp. 60 - 61. Ac II, 104. Tradução nossa.
} 
podem surgir falsas impressões com aparência de verdadeiras. Estas impressões confiáveis, mas não assertivamente determinadas como verdadeiras, são as impressões persuasivas (pithanê phantasia), que são verossimilhantes, mas não recebem nosso assentimento nem são apreendidas. $\mathrm{O}$ sábio cético deve se guiar pelas impressões persuasivas, suspendendo seu assentimento no primeiro sentido, mas mantendo-o no segundo, tornando-se capaz de agir, porém, incapaz de determinar a veracidade de suas impressões. Carnéades apresenta, aqui, a distinção entre assentimento e aceitação, ou aprovação. No assentimento aderimos a uma impressão por acreditarmos encontrar nela alguma marca distintiva da verdade. É o tipo de adesão dogmática que os céticos combatem. Na aprovação ou aceitação aderimos a uma impressão mesmo sem ter certeza sobre sua objetividade, com base em elementos que a distinguem como confiável, apesar de não atestadamente verdadeira, e no seu efeito sobre nós.

O que caracteriza as impressões persuasivas torna-se uma questão. Cícero é econômico acerca disto. Em Ac, II. 110, Cícero indica que a prática e a experiência ajudam a sustentar nossa aceitação das impressões. Em Ac, II, 104, ele afirma que as impressões persuasivas são aquelas que nos incitam à ação e não são impedidas por nada. Nem todas as impressões com estas características, no entanto, recebem nossa aprovação. Contanto que mantenhamos nossa suspensão e que nosso assentimento seja do tipo fraco, a aceitação ou aprovação, podemos utilizar essas impressões como base para nossa ação e até como resposta para os questionamentos feitos pela argumentação cética. Fica patente que Carnéades concebe as impressões persuasivas como o critério de ação e de verdade, num sentido de aprovação.

Este último ponto também é aceito por Sexto Empírico. No entanto, sua exposição fornece elementos esclarecedores complementares à exposição de Cícero. Em HP, I 229-30 e em AM, VII, 166-189 o critério de Carnéades é dividido em três: 1) impressões persuasivas; 2) impressões persuasivas e não controversas; 3) impressões persuasivas, não controversas e analisadas detalhadamente. É curioso o fato de Sexto apresentar três critérios para Arcesilau, quando na verdade os critérios 2 e 3 poderiam ser entendidos como características das impressões persuasivas. Vejamos como Sexto define essas características: 
No caso da que não é controversa, o requisito é apenas que nenhuma das aparências no conjunto deve nos desviar se tornando falsa, mas que todas elas devem parecer e ser verdadeiras e não serem inconvincentes. Mas no caso do conjunto associado às impressões exploradas completamente, nós escrutinamos cuidadosamente cada uma das aparências no conjunto - que é o tipo de coisa que acontece em assembleias (...). ${ }^{15}$

Percebe-se a abertura de Carnéades para a tentativa de julgamentos, mesmo que se conceba a todo o tempo como eles podem falhar. Consta aqui até mesmo o tipo de julgamento comum, ao qual Sexto diz aderir quando afirma que o cético se guia pelos costumes e pelas observâncias diárias. É curioso que Sexto tenha se oposto, em HP, I, 230, ao tipo de adesão a uma impressão que Carnéades utiliza. Nesta passagem, afirma-se que os pirrônicos e os acadêmicos se diferenciam pelo fato de aqueles "acompanharem" as aparências sem inclinação ou aderência, enquanto estes, mais especificamente Carnéades e Clitômaco, "acompanham" as impressões tendo um forte desejo e uma forte inclinação. Tal avaliação nos parece deslocada em relação à apresentação que Cícero faz de Carnéades, pois se tal desejo e inclinação partem, sim, de uma atividade racional e deliberada, não carregam consigo a adesão no sentido forte, o dogmático. Striker, ${ }^{16}$ por exemplo, aponta que o "acompanhar" dos pirrônicos corresponde ao "aprovar", também não dogmático, dos acadêmicos. Assim, mesmo que os pirrônicos consigam um critério de maneira passiva, o fenômeno, e os acadêmicos consigam o seu critério de modo ativo, o plausível, ambos aderem ao seu critério de modo não dogmático, sem considera-lo absolutamente verdadeiro, sustentando uma crença no sentido fraco do deste termo. Isto parece nos fornecer mais um motivo de aproximação entre os pirrônicos e os acadêmicos, além daquele obtido através do tipo de argumentação utilizado por ambos, aquela que defende todos os lados conflitantes de uma discussão como igualmente fortes ou fracos com vistas à suspensão dos juízos, apesar de os pirrônicos o fazerem com intenções terapêuticas e os acadêmicos o fazerem com o intuito de manter os seus juízos livres das imposições das autoridades enquanto buscam conhecer algo. Desta forma, guardadas as diferenças apontadas, acreditamos poder delinear um entendimento geral do ceticismo antigo através da comum concepção entre pirrônicos e acadêmicos de uma atividade intelectual que busca estabelecer o conflito teórico insolúvel, ao qual segue-se a suspensão dos juízos acerca da

${ }^{15}$ EMPIRICUS, S., Against the Logicians, p. 38. AM, VII, 182. Tradução nossa.

${ }^{16}$ STRIKER, G., Academics versus Pyrrhonists, reconsidered, p.204. 
verdade investigada e a consequente necessidade de adesão a um critério de verdade que não se impõe como absoluto, necessário e universal.

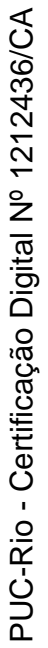




\section{CAP II - A transmissão e o impacto da retomada do ceticismo antigo}

O recente interesse pelas correntes céticas da Modernidade trouxe consigo o desenvolvimento de pesquisas históricas e filosóficas acerca da retomada dos textos céticos da Antiguidade. Apesar de haver discussão sobre qual é a real relevância da redescoberta dos textos céticos dos antigos para a formação do pensamento Moderno, parece consenso que estes textos foram retomados amplamente somente no Renascimento, que foram importantes em alguma medida para o pensamento renascentista e fundamentais para a formação do pensamento moderno, sobretudo a obra de Sexto Empírico, à qual os comentadores atribuem a responsabilidade pelo abastecimento de um conhecimento mais amplo e refinado sobre o ceticismo antigo. É o que sustentam Richard Popkin, Charles B. Schmitt e Luciano Floridi, por exemplo.

Os escritos originais dos céticos da Antiguidade não perduraram até nossa época. O que nos restou foram compilações destes escritos, textos de inspiração cética e testemunhos sobre a doutrina cética. Uma de nossas melhores fontes, certamente a mais abrangente, é a obra de Sexto Empírico. Este, por volta do final do século II da era cristã, foi mais um compilador do que um desenvolvedor do movimento cético pirrônico. Na categoria de texto inspirado no espírito cético, temos o diálogo Academica de Cícero, escrito presumivelmente em meados do primeiro século da era cristã, onde um dos participantes defende com desenvoltura a posição dos céticos acadêmicos. No que tange aos relatos sobre a doutrina cética, temos As Vidas dos Filósofos Ilustres de Diógenes Laercio, obra provavelmente escrita no início do século III da era cristã, onde encontramos a mais antiga tentativa de relatar o desenvolvimento da filosofia grega da Antiguidade.

Durante o Renascimento ressurge o interesse pela posição cética, o que ocasiona a formação do ceticismo na Modernidade. Segundo Charles B. Schmitt ${ }^{17}$, tal fato se dá sobretudo pela retomada dos textos antigos relativos ao 
assunto, pois não há texto na tradição medieval cristã que apresente uma argumentação filosófica tão refinada e sistemática de viés cético quanto a obra de Sexto Empírico. Porém, há de se considerar que durante a Idade Média pode-se perceber a existência de certos traços dos problemas levantados pelos céticos antigos, o que possivelmente poderíamos chamar de um protoceticismo moderno, mesmo com a ausência da influência direta da argumentação lógica e epistemologicamente bem delimitada dos céticos gregos, que parece ser uma tradição sem continuidade com este possível protoceticismo medieval. Guilherme de Ockham (1288 -1347) é um exemplo de uma possível abordagem protocética, pois constata-se em seu pensamento o interesse em pesquisas lógicas e epistemológicas a partir de uma abordagem crítica a Aristóteles. Nicholas de Autrecourt (ca. 1300 - ca. 1360), do qual quase nada se sabe, é outro caso de uma possível abordagem cética medieval. Contudo, estes autores provavelmente só tiveram acesso indireto aos textos dos céticos gregos e seus propósitos ao usarem uma abordagem próxima da argumentação cética certamente não era pirrônico ou acadêmico, dada a origem e as finalidades religiosas destes homens. A própria ausência da palavra scepticus e seus cognatos na língua latina até o século XV parece ser um indício de que as tendências medievais nas quais identificamos algum tom cético não possuem filiação direta com os céticos gregos. Tais traços de uma orientação que podemos aproximar do ceticismo são encontrados em pensadores religiosos de cunho anti-intelectualista e em escritores de origem judaica e hebraica. Contudo, nos limitaremos aqui à primeira característica incentivadora da retomada moderna do ceticismo, apontando informações relevantes acerca da retomada e do impacto causado no momento da releitura dos céticos antigos.

Devido a peculiares circunstâncias, os textos céticos antigos foram praticamente desconhecidos durante a Idade Média. Floridi ${ }^{18}$, por exemplo, apresenta razões linguísticas, epistemológicas e teológicas com o intento de explicar tal fato. Na Europa ocidental, durante a Idade Média, não era comum nem mesmo as pessoas educadas saberem grego, o que afastou o acesso direto às fontes originais. Cícero passa a ser a fonte mais acessada, mesmo que pouco. Isso

17 SCHMITT, C. B., The Rediscovery of Ancient Skepticism in Modern Times, pp. 228-229.

${ }^{18}$ FLORIDI, L., Sextus Empiricus: The Transmission and Recovery of Pyrrhonism, p. 15. 
resulta na identificação comum que se percebe entre as denominações "cético" e "acadêmico". Isto se percebe a partir do século V em Santo Agostinho, por exemplo. Floridi diz que o concurso de um forte senso realista e o dogmatismo religioso do cristianismo, que centralizou na Bíblia a fonte do conhecimento restringindo as pesquisas mundanas de acordo com os interesses teológicos, são fatores que ajudam a explicar como durante oito séculos. Desde o ataque aos céticos feito por Santo Agostinho, até John de Salisbury, os quais dependem de Cícero como fonte, as informações relativas ao ceticismo grego e a Sexto Empírico não estiveram disponíveis, não foram amplamente difundidas e nem discutidas. Outro foi o quadro encontrado na Europa bizantina, onde foi possível o contato com as fontes originais e se percebe um ataque à dúvida cética na figura de Pirro, por exemplo, no século $\mathrm{VI}^{19}$, mesmo sem a aparente existência de algum proeminente defensor do ceticismo.

Alguns textos nunca foram encontrados e os que nos restaram só foram retomados e assimilados durante os séculos XV e XVI. Este é o caso das três principais fontes restantes, citadas acima. No século XVII o ceticismo emerge como uma tendência importante tanto no pensamento filosófico quanto na teologia, na ciência e na literatura. A partir deste século até o século XIX, o ceticismo progressivamente passará a ter usos antirreligiosos, porém, este não é o quadro dos Séculos XV e XVI, nos quais a argumentação cética indagou se o ser humano poderia ter algum conhecimento por meios naturais ou não. Parece que raramente, se alguma vez, o arsenal cético foi usado contra a religião neste último período. Nestes séculos de Renascimento, a tendência filosófica chamada de fideísta é uma prova dos usos religiosos da argumentação cética, pois o fideísmo sustenta que a capacidade racional é limitada e não nos possibilita o acesso à verdade, que só pode ser atingida pela via da fé. Tal tendência distingue-se do ceticismo antigo, pois enfatiza não a natureza do conhecimento, mas nossa atitude frente à Revelação e o redirecionamento de nossa ação para o horizonte da fé cristã, ao explorar as fraquezas do conhecimento humano. Apresentaremos agora os dados relativos à retomada dos textos mais fundamentais sobre o ceticismo antigo em ordem de aparecimento na tradição ocidental europeia.

\footnotetext{
${ }^{19}$ Ibid., p. 20. Floridi se refere ao poeta Juliano, o egípcio, que dedicou um epigrama sepulcral ironizando a postura cética de Pirro.
} 


\section{1 - Cícero}

A obra de Sexto Empírico e o Academica de Cícero, que são as fontes mais ricas, foram pouco conhecidas durante a Idade Média. Até a sua época, Santo Agostinho (354 - 430 d. C.) falava do ceticismo acadêmico como uma força viva, um problema importante. Seu primeiro trabalho considerado de peso é Contra Academicos, onde a postura acadêmica exposta por Cícero é duramente atacada. Cícero foi um dos autores mais estudados neste período. Mesmo que existam manuscritos datados de antes do século XIV, referências em diversos autores medievais e cópias em diversas bibliotecas medievais, este diálogo de Cícero não teve a mesma atenção e impacto que outros textos do mesmo autor. As referências ao diálogo ciceroniano em questão são poucas e, sobretudo, baseadas em sua apresentação feita no diálogo Contra Academicos de Santo Agostinho, texto mais lido do que o próprio Academica.

Apesar do crescente interesse pelo diálogo cético de Cícero durante os séculos XIV e XV, é somente em meados do século XVI que ele começa a ser levado mais a sério. Sabendo da atenção e importância atribuídas a Cícero na formação do Humanismo renascentista, é curioso o fato de um texto deste mesmo autor, porém, de tintura cética, não ter sido observado nas discussões que assumiram um caráter cético. Cícero era muito conhecido e respeitado pelos seus dotes oratórios, retóricos e refinação argumentativa filosófica. Considere-se que durante o Renascimento, Cícero ainda não era visto como um propagador de doutrinas filosóficas gregas, mas sim como um sábio e grande filósofo. Mesmo que a primeira edição impressa do Academica e outros diálogos de Cícero tenham aparecido em 1471, não se encontra preocupação, seja filológica, histórica ou filosófica com relação a este diálogo antes de 1536, ano em que Pier Vettori (1499- 1585) publica em Veneza Explicationes suarum in Ciceronem castigationum, uma série de comentários sobre o texto ciceroniano em questão. Os comentários feitos no século XVI ao diálogo de Cícero versam majoritariamente sobre o caráter filológico de sua leitura, não o filosófico. 
Mesmo sem documentação, mas como hipótese explicativa que lhe parece plausível, Schmitt ${ }^{20}$ acredita que um desconcerto do homem do Renascimento acerca de como interpretar o ataque ciceroniano à autoridade desta tradição poderia ser a causa da pouca influência do diálogo Academica nesse período. Deste modo, teria sido difícil de coadunar a imagem renascentista que se tinha de Cícero com a diferente postura cética acadêmica de forte crítica à tradição filosófica epicurista, estoica, platônica e aristotélica.

Na metade final do século XVI surgiram outras anotações do Academica, contudo sem causarem impacto ou inovação visível e, portanto, parecem não ser de grande interesse para a história da transmissão do ceticismo. Também há nesse mesmo período o surgimento de algumas obras inspiradas no Academica que merecem ser mencionadas. Em ordem cronológica podemos enumerar as seguintes publicações: 1) Academia eiusdem in Academicum Ciceronis fragmentum explicatio, de Omer Talon, em 1547, em Paris, e na edição publicada em 1550 incluiu-se um comentário ao Luculus, a segunda seção do Academica; 2) Adversus Marci Tullii Ciceronis academicas quaestiones disputatio, de Giulio Castellani, em 1558, em Bolonha; 3) In reliquas Academicarum M. Tullii Ciceronis \& eiusdem quinque libros de finibus Iohannis Rosae comentarius, de Johannes Rosa, em 1571, em Frankfurt; e 4) Academica sive de indicio erga verum, ex ipsis primis fontibus, de Pedro de Valencia, em 1596, em Antuérpia.

Juntamente com Petrus Ramus (1515 - 1572), Omer Talon (1510 - 1562) buscou renovar o curriculum universitário escolástico aristotélico ensinado em Paris desde o século XIII, substituindo-o por um curriculum mais humanístico, onde ecoava um humanismo do Quattrocento italiano. Talon parece ter escrito esta obra com o intuito de indicar a existência de outras alternativas filosóficas ao aristotelismo que vigorava em sua época e para mostrar que nem mesmo a autoridade aristotélica mantinha-se incólume frente aos ataques céticos a todo o dogmatismo filosófico. Talon faz uma exposição do desenvolvimento do ceticismo acadêmico desde Platão até Carnéades, examinando suas raízes socráticas e pré-socráticas, baseado no relato de Cícero. Esta, que segundo Popkin $^{21}$, talvez tenha sido a maior exposição do ceticismo acadêmico à época,

\footnotetext{
${ }^{20}$ SCHMITT, C. B., The Rediscovery of Ancient Skepticism in Modern Times, p. 229-30.

${ }^{21}$ POPKIN, R., História do Ceticismo de Erasmo a Spinoza, pp. 66 - 67.
} 
aparentemente visava à justificação dos ataques ao aristotelismo e ao despertar para o fato de a verdadeira filosofia dever ser livre em seus julgamentos, libertando assim muitos da prisão exercida pela autoridade. Popkin também aponta a presença em Talon da importante distinção entre um ceticismo contra a razão e um ceticismo contra a religião, domínio no qual Talon considerava que se deve crer para entender. Em resposta, Pierre Galland (1510 - 1559), em sua obra Pro schola Parisiensi contra novam academiam Petri Rami oratio, publicada em 1551, em Paris, atacou Talon e os seguidores de Ramus por preconizarem uma doutrina que leva à incerteza ao atacarem os aristotélicos com as armas dos céticos acadêmicos. Este parece ser o mesmo ambiente no qual se inseriu a obra de Guy de Bruès, Les dialogues contre les nouveaux academiciens, publicada em 1557, de pouco refinamento teórico, mas também intencionada em proteger os fiéis dos possíveis desvios ocasionados pelos argumentos céticos. Tal dinâmica parece indicar uma possível reinserção do ceticismo acadêmico na discussão intelectual parisiense da segunda metade do século XVI.

Já na Itália, quase simultaneamente à discussão ocorrida na França, Giulio Castellani publica seu parecer acerca do Academica de Cícero. Reconstruindo a argumentação cética aí contida, Castellani escreve uma das mais significantes tentativas de refutação da posição cética, ponto por ponto, do seu século. Aqui o ceticismo acadêmico é rejeitado não por levar à negação da religião, mas por eliminar a possibilidade de uma filosofia sólida.

Na Alemanha, Johannes Rosa é quem reaviva o diálogo cético de Cícero. O comentário a esta obra que Rosa publicou em 1571, não teve segunda edição e aparentemente não teve repercussão no meio acadêmico alemão da época, apesar das escassas pesquisas sobre a difusão do Academica na Alemanha do século XVI. Há de se considerar que, diferentemente de Talon, Castellani e Valencia, Rosa era protestante, fato que indica o alcance do texto de Cícero. Johannes Rosa foi educado em Wittemberg, ensinou na universidade de Jena e tornou-se um de seus primeiros reitores. Este comentário de Rosa é digno de atenção, pois sua atitude é ambígua. Ele assevera o valor do Academica no ensino tanto pela sua lição dada contra a precipitação e contra a adesão acrítica às doutrinas dogmáticas, quanto por mostrar que se deve evitar a arrogância quando da posse de algum conhecimento. Mas também aponta um perigo no diálogo de Cícero, pois este pode tanto apaziguar o desejo do conhecimento quanto incentivar a descrença, 
pelo desuso das nossas capacidades cognitivas doadas por Deus, que são seriamente atacadas no Academica.

Nossa última menção ao interesse pelo Academica no século XVI é a obra homônima do espanhol Pedro de Valencia. Esta é uma cuidadosa análise histórica do desenvolvimento do ceticismo acadêmico antigo. Por isso, frequentemente foi reimpressa e traduzida até o século XVIII, tendo considerável circulação e valor acadêmico até o século XIX. Nela também encontra-se a posição de Valencia, que se aproxima do fideísmo ao considerar o ceticismo acadêmico como uma preparação para a percepção de que só em Deus se encontra uma fonte de conhecimento.

\section{2 - Diógenes Laercio}

A vida deste autor é ainda controversa e relativamente desconhecida. Pelas referências que cita, pressupõe-se que viveu por volta do século III e teria escrito As vidas e Doutrinas dos Filósofos Ilustres nas primeiras décadas deste mesmo século. A primeira tradução latina desta obra foi a do humanista italiano Ambrogio Traversari, em 1430. Esta tradução circulou amplamente pela Itália em forma de manuscrito durante o século $\mathrm{XV}$, foi reproduzida em dezenas de outros manuscritos e outras traduções italianas neste mesmo século e foi impressa pela primeira vez em 1472, em Roma.

Esta é uma obra que apresenta o desenvolvimento da filosofia grega antiga de modo geral, assumindo às vezes um caráter anedótico ao apresentar elementos biográficos dos pensadores gregos. Nela não fica clara a posição própria de Diógenes. Poucas de suas seções tratam do ceticismo. Em especial temos a Vida de Pirro, capítulo que particularmente parece ter sido desconhecido na Idade Média e só disponibilizado para o mundo intelectual ocidental a partir de Traversari. Esta nova fonte foi utilizada largamente no século XV como complemento das outras fontes latinas sobre o ceticismo, disponíveis antes da retomada de Sexto Empírico no século XVI. 
Segundo Schmitt ${ }^{22}$ é importante mencionar que a palavra scepticus parece ter sido introduzida no vocabulário da língua latina a partir desta tradução de Traversari. Antes disso só se encontra em duas ocasiões. Na primeira, em manuscritos de Noctes atticae, texto do século II, de Aulus Gellius. Mas, aqui, ela aparece com caracteres gregos e num contexto que torna seu uso fora do comum. $\mathrm{Na}$ segunda ocasião, esta palavra aparece em duas traduções medievais manuscritas de Sexto Empírico, porém, estas não tiverem impacto algum no seu ambiente intelectual. Conforme as pesquisas de Schmitt, a palavra scepticus e suas derivações não foram utilizadas durante a Idade Média, gradualmente foram sendo mais comumente usadas durante o século XV e ao fim do século XVI já estavam firmemente estabelecidas no vocabulário comum.

\section{3 - Sexto Empírico}

Como dito anteriormente, a principal fonte do ceticismo antigo que chegou até nós é a obra de Sexto Empírico. Rica em abrangência e refinamento teórico, ela trata tanto das bases quanto da aplicação do ceticismo aos discursos dogmáticos. Esses textos, contudo, tiveram sua existência praticamente desconhecida no Ocidente antes do século XV. Durante toda a Idade Média, entre os cristãos gregos do Império Bizantino, o ceticismo teve pelo menos algum papel na discussão teológica e doutrinal do Cristianismo Oriental. Por exemplo, em torno de 379, Gregório de Nazianzo (330 - 389 d. C.) em sua Oração XXI ataca a voz cética de oposição que parecia ter adentrado as Igrejas e tenta expulsá-la conjuntamente com a toda a filosofia grega em geral que, em sua consideração, era incompatível com o cristianismo. Sabemos que posteriormente, curiosamente, algumas tentativas de aproximar a filosofia grega do cristianismo serão feitas, por exemplo, por Santo Agostinho, contemporâneo de Gregório de Nazianzo.

\footnotetext{
${ }^{22}$ SCHMITT, C. B., The Rediscovery of Ancient Skepticism in Modern Times, p. 233. E também em SCHMITT, C. B., Cicero Scepticus: A Study of the Influence of the "Academica" in the Renaissance, pp. $12-13$.
} 
Há referências a Pirro e Sexto Empírico também nos séculos V, VI, IX, XII e XIV. Algumas delas levam a crer que alguns textos céticos da antiguidade, hoje perdidos, ainda eram acessíveis, como nos mostra a referência a Enesidemo na Bibliotheca de Photius, onde constam informações inexistentes nas fontes que nos restaram. No Século XIV parece haver novamente um crescimento de interesse pelos problemas levantados pelo ceticismo. Restaram pelo menos os trabalhos de quatro pensadores bizantinos: Theodoros Metochites $(1260$ - 1322) e sua crítica renovada aos danos que podem ser causados ao cristianismo pelo pirronismo; Nicephoros Gregoras (1290\1 - 1359\60) e sua paráfrase do pensamento de Gregório Nazianzo; Gregório Palamas (129617 - 1359) que mostrava conhecimento da problemática cética; e Nicholas Cabasilas (1322\3 1391?), autor de um tratado que contém a mais detalhada evidência da persistência do interesse pelo ceticismo grego na Idade Média. O Império Bizantino não teve, segundo Floridi ${ }^{23}$, o problema linguístico de desconhecimento da língua grega e teve o acesso direto a algumas das fontes originais, hoje inexistentes. Inclusive, vem da tradição bizantina o mais antigo manuscrito conhecido de Sexto Empírico, que data do século IX ou X, e que foi trazido por Emmanuel Miller para a Europa de sua viagem ao Oriente e foi recentemente encontrado separadamente em três fólios localizados em Vienna, em Roma e em Paris. Há de certa forma referências ao ceticismo, o que não indica uma aceitação do mesmo, pois todas, em uníssono, criticam tal postura filosófica como altamente impiedosa e, portanto, reprovável.

A Europa Ocidental toma contato com ceticismo grego somente em 1427, quando Francesco Filelfo (1398 - 1481) leva consigo para a Itália manuscritos da obra de Sexto Empírico trazidos de Constantinopla. A partir daí diversos pensadores do humanismo italiano passam a apresentar indícios de conhecimento das obras de Sexto Empírico e cópias destas obras são dispostas em bibliotecas como a dos Médici, a do Vaticano e na Biblioteca de São Marco em Florença. Provavelmente, por volta de 1485, Giovanni Lorenzi fez uma tradução parcial desta obra e poucos anos mais tarde Girolamo Savonarola (1452 - 1498) afirmava tê-la traduzido completamente com o auxílio de parceiros. Não se tem certeza sobre esse feito, dado que tal documento não sobreviveu até nossa época.

\footnotetext{
${ }^{23}$ FLORIDI, L., Sextus Empiricus: The Transmission and Recovery of Pyrrhonism, p. 22.
} 
Tais dados sustentam que houve algum interesse pelo ceticismo grego nos centros intelectuais da Itália renascentista do século XV, como Roma, Veneza e Florença. Todavia, Schmitt julga que tais textos eram utilizados com interesses provavelmente históricos e filológicos, fato que não caracterizaria a instauração de uma crise pirrônica. Esta, conforme Popkin ${ }^{24}$ tem seu advento no início do século XVII em meio ao questionamento sobre o critério da fé na crise intelectual da Reforma. Brian P. Copenhaver e Schmitt ${ }^{25}$ também concordam que durante o Renascimento não houve tal instauração de uma crise cética, pois indicam o ceticismo como mais uma das tendências filosóficas reavivadas pelo movimento intelectual renascentista, e ainda assim, atribuem à dúvida dos antigos um lugar modesto nesse processo. É consenso que a retomada dos textos de Sexto Empírico é o fator determinante para o surgimento do interesse Moderno pelo ceticismo antigo e para o início da formação da variedade moderna do ceticismo.

Sabe-se da existência de três códices medievais de uma tradução latina anônima das Hipotiposes Pirrônicas. Pertencentes ao início do século XIV, foram encontrados na Biblioteca Nazionale Marciana, em Veneza; Na Biblioteca Nacional, em Madrid; e na Bibliotèque Nationale, em Paris. Entretanto, não se tem evidências de que essas traduções foram lidas por um público e tiveram alguma repercussão.

O primeiro ocidental a mostrar sério interesse direto pelo potencial destrutivo teórico do ceticismo grego, já no século XVI, foi Gianfrancesco Pico della Mirandola (1469 - 1533). Ele teve aceso direto à obra de Sexto Empírico em grego, o que lhe deu base para seu Examen Vanitatis Doctrinae Gentium, obra finalizada em 1516 e publicada em 1520, onde ataca a filosofia aristotélica e sua epistemologia baseada nos sentidos em defesa do acesso à verdade através das Escrituras Sagradas. Richard Popkin e Charles B. Schmitt discordam acerca da influência desta obra e de sua capacidade de ser um meio de divulgação do ceticismo, tal qual o foi posteriormente A Apologia de Raymond Sebond, um dos Ensaios de Michel de Montaigne. Enquanto Schmitt acredita ter havido alguma atenção voltada para o Examen Vanitatis, Popkin afirma que alguma influência pode ter exercido, mas tal obra está longe de ser uma das responsáveis por tornar

\footnotetext{
${ }^{24}$ POPKIN, R., História do Ceticismo de Erasmo a Spinoza, p. 25.

${ }^{25}$ COPENHAVER, B.P. \& SCHMITT, C. B., Renaissance Philosophy. Oxford: Oxford University Press, 1992.
} 
o ceticismo uma das questões da época, apesar de ambos concordarem que Gianfrancesco Pico dela Mirandola parece ter sido o primeiro ocidental a se preocupar com Sexto Empírico antes da primeira publicação da tradução latina das Hipotiposes, em $1562^{26}$. Ao nosso julgamento, fato que por si só já confere algum interesse ao Examen Vanitas.

Possivelmente, a primeira tradução que se conhece é de Joannes Paéz de Castro datável entre 1550-1575 ${ }^{27}$. Porém, a tradução latina das Hipotiposes feita por Henri Estiene (1528 - 1598) e publicada em 1562, em Genebra, é que parece ser mais impactante. Estiene publicou conjuntamente desta tradução, no mesmo volume, A Vida de Pirro de Diôgenes Laêrtios, De Optimo docendi genere liber de Galeno, um index em ordem alfabética e suas anotações à tradução. Ela foi reimpressa em 1569, 1619, 1621, 1652 e 1659.

A tradução das Hipotiposes feita por Estiene declara em sua introdução o patente desejo tanto de curar o dogmatismo impiedoso através da epoché pirrônica, quanto de libertar os amantes da filosofia de um longo e tedioso trabalho. Nesta introdução, também é declarada a não adesão o ceticismo como postura filosófica própria. Contra a possível pergunta sobre o sentido, portanto, de sua publicação, Estiene responde que as Hipotiposes podem ajudar desobstruindo as nuvens dogmáticas, anulando-se em conjunto com o dogmatismo que combate e abrindo o caminho para a luz da verdade cristã ${ }^{28}$. Assim, através de uma interpretação que percebe no ceticismo uma ferramenta metodológica, nos parece que Estiene estava convencido do auxílio das Hipotiposes no aprendizado. Posteriormente a Modernidade enfatizaria esse uso epistemológico do desafio cético. Como resultado, a visão de Estiene propõe um anti-intelectualismo que indica a urgência moral de uma reforma cultural, a mudança da atitude mental em relação ao conhecimento. Tal mudança consiste na condenação da curiosidade científica em detrimento da sábia ataraxia, seguindo-se a isto uma interpretação ética do ceticismo como uma força moral capaz ultrapassar as discussões vãs e os preconceitos dogmáticos ${ }^{29}$.

\footnotetext{
${ }^{26}$ POPKIN, R., POPKIN, R., História do Ceticismo de Erasmo a Spinoza, pp. 54 - 55. Também em SCHMITT, C. B., The Rediscovery of Ancient Skepticism in Modern Times. p. 236.

${ }^{27}$ FLORIDI, L., Sextus Empiricus: The Transmission and Recovery of Pyrrhonism, p.70.

${ }^{28}$ Ibid., p. 75.

${ }^{29}$ Ibid., p. 76.
} 
Já Adversus Mathematicos tem sua primeira tradução conhecida na Idade Média (de $A M$, III. 37 a $A M$, V.25) localizada em um manuscrito também encontrado na Biblioteca Nazionale Marciana, em Veneza. Provavelmente feito pelo mesmo tradutor do manuscrito das Hipotiposes que aí se encontra devido ao estilo da escrita, apesar da diferente caligrafia. No Renascimento surgem outras traduções parciais de $A M$. Duas atribuídas a Giovanni Lorenzi (ca. 1440 - 1501). A primeira de $A M$, I - IV, encontrada na Biblioteca Apostolica Vaticana, em Roma. A segunda, de $A M$, I - III, encontrada na Biblioteca Nazionale Universitaria, em Turin. Uma diferente tradução manuscrita atribuída a Johannes Wolley (ca. 1530 - 1596) e provavelmente produzida entre 1553 e 1563 foi encontrada por Richard Popkin nos anos 1960's na Bodleian Library, em Oxford. A primeira tradução completa e publicada de $A M$ ficou a cargo de Gentian Hervet (1528 - 1598). Esta primeira edição veio ao público em 1569, na Antuérpia. Ela é acompanhada da tradução das Hipotiposes publicada alguns anos antes por Henri Estiene. 


\section{CAP III - Vida e Obra de Sanches}

Raymond Delassus, discípulo de Sanches, foi primeiro a escrever uma biografia do seu mestre, a pedido dos filhos de Sanches, Guilherme e Denis, a qual foi publicada em 1636 junto com todos os escritos médicos e filosóficos deste. Delassus afirmou ter sido a cidade portuguesa de Braga o lugar de nascimento de Sanches. Em uníssono, todos os comentadores de Sanches passaram a também apresentá-lo como português natural de Braga.

Tal avaliação contrasta com a de Henri P. Cazac, que publicou em 1903 estudos documentais onde se conclui que Sanches nasceu em Tuy, na Galícia espanhola por volta de $1550^{30}$. Cazac assegura sua conclusão sobre a naturalidade de Sanches no fato de este mesmo tê-lo declarado, por escrita de punho próprio, em 21 de Outubro de 1573, ao efetuar sua matrícula na Universidade de Montpellier: Ego, Franciscus Sánchez, Hispanus natus in civitate Tudensi. Instaura-se, assim, um longa disputa entre portugueses e espanhóis pela nacionalidade do filósofo e médico.

De fato sabe-se que Sanches foi batizado na Igreja de São João do Souto, em Braga, no dia 25 de Julho de 1551, pois se encontrou o registro de seu batismo no Registro Civil de Braga onde as informações de filiação já conhecidas são corroboradas: "Aos vinte e cinco dias de Julho batizei Francisco filho de Antônio Sanches físico e de sua mulher Filipa de Souza." 31 Porém, Cazac aponta que desde o século XI, Tuy fazia parte do bispado sufragâneo de Braga. Deste modo, se nasceu de fato em território geográfico espanhol, devemos acrescentar que tal território, no momento do nascimento de Sanches estava sob jurisdição eclesiástica da Arquidiocese de Braga. Esta interpretação de Cazac parece sustentar-se no que tange à nacionalidade, pois conforme aponta Joaquim de Carvalho $^{32}$, a Diocese de Braga exigia que o batismo fosse feito não depois de

${ }^{30}$ CAZAC, H. P., Le lieu d'origine et les dates de naissance et de mort du philosophe Francisco Sánchez. In: Bulletin Hispanique. Tome 5, N4, 1903. pp. 326-348.)

${ }^{31}$ MORAES FILHO, E., de Francisco Sanches na Renascença Portuguesa, p. 34.

${ }^{32}$ SANCHES, F., Opera Philosophica, p. 161. 
nove dias após o nascimento do bebê. Apesar da possibilidade de tal obrigação não ter sido cumprida, tal informação nos impõe a necessidade de deslocar o nascimento de Sanches de 1550 para 1551.

Conforme Severiano Tavares ${ }^{33}$, grande estudioso da vida de Sanches, podemos ainda nos perguntar por que, além de Delassus, o próprio Sanches também se referia a si em algumas oportunidades como bracarense? Como é o caso das seguintes ocasiões formais acadêmicas registradas em Montpellier: na ata de seu Bacharelado, em 23 de Novembro de 1573, "Ego Franciscus Sanctius, Hispanus, dioceses Bracarensis..."; na licenciatura, em 29 de Abril de 1574, "Ego Franciscus Sanchez Bracarensis dioceses...”; em seu Doutorado, em 13 de Julho de 1574, "Ego Franciscus Sanchez, Hispanus, dioceses Bracarensis...". Há ainda o quadro de Sanches que se encontra na faculdade de medicina de Toulouse, onde está escrito: "Franciscus Sanches, lusitanus...".

Quanto à denominação "Hispanus", podemos considerar que à época este adjetivo referia-se, de um modo geral, à origem de alguém nascido na Península Ibérica, portanto, não necessariamente na Espanha, mas também em Portugal. Note-se a insistência na referência à diocese de Braga, não à cidade de Braga. Com relação a esta referência, Severiano Tavares explica que desde 1393 Tuy não fazia mais parte das províncias eclesiásticas de Braga. Portanto, a Tuy à qual Sanches se refere não pode ser a Tuy espanhola que ainda hoje existe e que faz fronteira com Valença do Minho, em Portugal. Pesquisas históricas mostraram a Severiano Tavares que existiu em tempos remotos, na margem esquerda do Rio Minho, um castelo chamado Tuy, Tyde ou Tuyde, e ao redor, ou próximo, a este castelo instaurou-se um povoado que se apropriou do nome do mesmo castelo. Desta cidade saíram os fundadores da Tuy espanhola do outro lado do rio. Para distingui-las, os moradores chamavam esta de Tuy Nova e aquela de Tuy Velha. Há manuscritos até o século X que designam a cidade de Valença com o nome de Tuy Velha. Com esta hipótese Severiano Tavares parece ter fornecido boa explicação para insistência de Sanches em apresentar-se como natural da Diocese de Braga e não da cidade de Braga, e o fato de ele apontar Tuy como sua cidade natal. Deste modo, Sanches possivelmente teria nascido em Valença em 1551. Como mais um elemento que corrobora tal hipótese, podemos acrescentar a

${ }^{33}$ TAVARES, S., Francisco Sanches e o problema da sua nacionalidade, pp. 63-76. 
descoberta, feita Mario Martins ${ }^{34}$, de um comentário biográfico de Sanches feito pelo erudito jesuíta português João Soares de Brito, nascido em 1611. A obra publicada em Coimbra, em 1655, Theatrum Lusitaniae Littevarium sive Bibliotheca Scriptorum omnium Lusita- norum. Auctore Joanne Soares de Britto, diz as seguintes palavras sobre Sanches: Franciscus Sanches, patria valentinus in Dioecesi Braccarensi. Segundo Mário Martins, este erudito seiscentista não estava inserido nessa disputa pela nacionalidade de Sanches, que nem mesmo existia ainda, o que pode ser um argumento a favor da imparcialidade desta informação e para a confirmação da hipótese de Sanches ser natural de Valença (a Tuy Velha), na Diocese de Braga.

Sanches residiu e fez seus primeiros estudos em Braga até 1562, quando seu pai decide mudar-se com a família para Bourdeaux, conforme o relato de Delassus. Não se sabe exatamente por qual motivo. Sabe-se que o irmão do pai de Sanches, Adam-Francisco Sanches, vivia nesta cidade. As prováveis razões desta mudança, conforme diversos comentadores, possivelmente foram a melhor condição econômica, as melhores opções de educação e a maior tranquilidade política e religiosa que o ambiente francês oferecia em relação ao cenário português. Richard H. Popkin, por exemplo, indica a possível condição de novos cristãos dos pais de Sanches, que descendiam de proeminentes famílias de judias espanholas anteriormente à instalação da Santa Inquisição e da expulsão dos judeus. A família Sanchez, do lado paterno, e a família Lopez, do lado materno. O pai de Sanches, Antônio Sanches, era um conhecido médico, profissão que não era comumente exercida por cristãos na época, mas sim, frequentemente por judeus. Há ainda o parentesco entre Montaigne e Sanches, que eram primos distantes pelo lado materno. Popkin relata, inclusive, que ambas as famílias envolveram-se num plano para assassinar um líder da Inquisição. Estes e outros dados interessantes estão contidos nas caixas de documentos de Henri Cazac, na biblioteca do Institut Catholique de Toulouse ${ }^{35}$.

Tais documentos mostram também a existência da influência cética no Collège de Guyenne, onde Montaigne (entre 1539 a 1546) e Sanches (entre 1562 e

\footnotetext{
${ }^{34}$ MARTINS, M., Francisco Sanches era de Valença: um testemunho seiscentista, pp. 281-285.

${ }^{35}$ POPKIN, R. H., História do Ceticismo de Erasmo a Spinoza, p. 86, nota 118.
} 
1569 ou $1571^{36}$ ) estudaram. Aí lecionavam diversos cristãos novos portugueses e eram consideradas ideias céticas radicais. ${ }^{37}$ Gentian Hervet, por exemplo ensinou grego neste colégio no ano de sua fundação, $1533^{38}$. Conforme relata Artur Moreira de Sá ${ }^{39}$, desde o século XIII, quando ainda se chamava Collège des Arts, o Collège de Guyenne já era muito florescente, pois a posição geográfica de Bordeaux proporcionava o comércio com italianos, o que ocasionou a abertura para alguma influência renascentista nesta cidade, além de as ideias relativas à Reforma estarem bastante disseminadas em Bordeaux e igualmente presentes dentro do Collège de Guyenne por causa de alguns professores. O que não significa quer houvesse total aceitação destas ideias renascentistas e reformistas. Moreira de Sá cita o caso de George Buchanan, distinto humanista escocês, professor de latim nesta instituição, que fugiu devido às perseguições e teve que se refugiar na casa do pai de um de seus alunos, Montaigne.

Felizmente ainda existem registros do curriculum, da organização das séries e do colégio. Estes foram descritos em Schola Aquitanica, pelo humanista francês Elie Vinet, diretor e professor de matemática e de grego na escola durante os anos em que Sanches a frequentava. Elaine Limbrick $^{40}$, na introdução que escreveu para a tradução inglesa de Que Nada se Sabe feita por Douglas F. S. Thompson, nos relata estas informações. O maior objetivo do colégio era formar estudantes conhecedores da língua latina. As cartas, orações e tratados de retórica de Cicero eram os textos mais utilizados em todas as aulas, considerando a adequação com o nível de habilidade dos estudantes. Estes costumavam entrar na escola aos sete anos e se formavam após dez anos de estudos, aos dezessete anos de idade. A presença da retórica era progressivamente aumentada nos últimos quatro anos do curso, que contava ainda com o aprendizado de Grego por meio de preleções públicas e com o ensino de matemática nos dois últimos anos. E, como a Universidade de Bourdeaux tinha baixa reputação em artes, o Collège de Guyenne também oferecia os dois primeiros anos deste curso universitário. Este curso consistia, principalmente, no estudo da lógica aristotélica durante o primeiro ano, seguido pelo estudo de filosofia natural no segundo ano, no qual também

\footnotetext{
36 Há divergência quanto à duração deste período. Moreira de Sá e Sanchet, por exemplo, estabelecem 1562 - 1569, enquanto Limbrick diz 1562 - 1571.

${ }^{37}$ POPKIN, R. H., História do Ceticismo de Erasmo a Spinoza, p. 80, nota 101.

${ }^{38}$ BESNIER, B., Sanchez à Moitié Endormi, p. 103, nota 3.

${ }^{39}$ SÁ, A. M. de, Francisco Sanches, pp. $13-17$.

${ }^{40}$ SANCHES, F., That Nothing is Known, pp. $8-10$.
} 
predominava a leitura de textos de Aristóteles. No primeiro ano os estudantes eram chamados de dialecti, ou logici. No segundo ano eram chamados de physici. Limbrick aceita como mais do que provável a informação dada por Cazac de que Sanches teria seguido seus estudos nessa instituição até à maîtrise ès arts antes de partir para a Itália. Moreira de Sá ${ }^{41}$ acha pouco provável que Sanches tenha concluído este curso, o que pode ser um fator para que ele marque 1569 como ano de partida de Sanches para a Itália, seguindo Senchet, e diferindo de Limbrick que estabelece 1571 como ano em que Sanches deixa Bordeaux. Para corroborar sua aceitação desta informação Limbrick aponta um trecho de um tratado médico no qual Sanches descreve os sintomas da doença que matou seu pai e data esta observação no ano de 1571, portanto ele ainda estava em Bordeaux junto com a sua família e só partiu após a morte do pai. Esta é uma informação importante, pois indica o ambiente onde se gerou o ímpeto de autonomia intelectual e crítica, tão próprio à postura filosófica de Sanches.

Após o falecimento de seu pai o jovem estudante Sanches parte para uma viagem através de Languedoc e Provence até a Itália. Neste período, entre 1571 e 1573, também tomaria contato com elementos fortes da sua posterior postura filosófica e médica. Visitou as universidades italianas de Pisa, Bologna, Pádua, Veneza, Ferrara e Florença, fixando residência em Roma, onde vivia um primo de Lisboa, Duarte Paulo. Em sua estadia na Itália tomou contato com os avanços dos estudos anatômicos e fisiológicos, com as críticas à teoria aristotélica da demonstração e com as novas interpretações do Ars Medica de Galeno, obra onde a questão do método é tematizada. Desde a Antiguidade filosofia e medicina aproximaram-se. O próprio Sexto Empírico era médico e o seu nome se deve à identificação com o empirismo médico. A tradição galênica também propõe a ligação entre estas disciplinas. Na Itália mantinha-se desde a Idade Média até o Renascimento tal interdisciplinaridade, onde a lógica e a filosofia frequentemente eram tidas como preparação curricular para a medicina, de modo que era comum encontrar nos grandes centros universitários italianos conhecidos humanistas ensinando concomitantemente ambas as disciplinas.

Em 1572, Sanches ingressa na universidade de La Sapienza, em Roma, onde se primava pela observação da natureza como fator imprescindível para os

${ }^{41}$ SÁ, A. M. de, Francisco Sanches, p.10. 
estudos médicos. Grande centro de estudo aristotélico, esta universidade ofereceu o contato com estudos retificadores de traduções latinas do pensador estagirita, feitas por médicos e filósofos árabes que indicavam alguns usos medicinais errôneos e perigosos de plantas. A carreira médica posterior de Sanches revela a persistência do interesse por este campo de investigação da medicina. La Sapienza também ofereceu ao jovem estudante português a oportunidade de conhecer as novidades nos estudos sobre anatomia e a discussão sobre a propriedade dos ensinamentos de Galeno. Foi também em Roma que Sanches conheceu Christopher Clavius, famoso matemático jesuíta alemão, de quem pode ter sido aluno e com quem posteriormente se corresponderia por carta acerca de problemas na geometria euclidiana. Delassus diz que Sanches enviou um manuscrito de sua primeira obra Objectiones et Erotemata super geométricas Euclidis Demonstrationes, o qual não resistiu ao tempo, caso o relato do discípulo de Sanches seja verdadeiro. Da correspondência ocasionada pela conversa sobre as objeções de Sanches a Euclides só nos restou uma carta de Sanches que foi descoberta e publicada por Joaquim Iriarte ${ }^{42}$. Nesta carta Sanches apresenta-se e despede-se utilizando como codinome o nome do filósofo cético acadêmico Carnéades, tido como o mais hábil dialético da academia, caracterizado pela apresentação do plausível como critério de resposta para a possível paralização da vida que a dúvida cética, segundo os críticos, causaria. Ter presenciado as tradições aristotélica e a galênica, além de criticas a estas, em conjunto com o incentivo ao espírito da investigação direta da natureza parece ter sido uma experiência fundamental para Sanches.

Em 1573, retorna à França, onde se matricula no dia 21 de Outubro no curso de medicina na Universidade de Montpellier. Em 13 de Julho de 1574 obtém o seu Doutorado. Em 1573 ministrou um curso sobre cirurgia com a qualificação dada por seus conhecimentos em anatomia e cirurgia adquiridos na Itália. Em 1574 lecionou nesta Universidade na cadeira de medicina anteriormente à apresentação de sua candidatura no concurso para ocupar esta cadeira, recentemente disponibilizada pelo falecimento de François Feynes, orientador de

42 J. IRIARTE-AG., Francisco Sanchez, el Escéptico disfarzado de Carneades en discusión epistolar con Cristóbal Clavio. Un autógrafo inédito y una revalorización de su doctrina. In: Gregorianum, Vol. 21, No 2/4 (1940), pp. 413 - 451. 
Sanches em seus estudos na faculdade de medicina de Montpellier. Limbrick ${ }^{43}$ enumera possíveis razões para a partida de Sanches, de Montpellier para Toulouse: parece ter havido o favorecimento de um dos participantes do concurso para a cadeira de professor de medicina na Universidade de Montpellier, o que teria deixado Sanches descontentado; a indicação de Delassus que determina a atribulada situação de tensão civil e religiosa na cidade; e o prospecto de vacância da cadeira de medicina na Universidade de Toulouse, onde o professor regente Larroche se encontrava em delicada condição de saúde. Mesmo que menos voltada para a prática e mais conservadora do que Roma, Montpellier também parece ter tido algum valor para a formação de Sanches, pois aí também continuou seu contato com Aristóteles e Galeno.

Toulouse seria a última cidade habitada por Sanches, que aí ficaria até a sua morte em 1623. Seu objetivo de conseguir a cadeira de medicina nesta cidade só seria realizado em 1612, após o falecimento de seu amigo Manuel Álvares, que pode ter sido o responsável pela ida de Sanches até esta cidade. Em 30 de Abril de 1581 falece o professor regente Larroche, mas sua cadeira foi ocupada por Auger Ferrier. Em 1 de Janeiro de 1582 Sanches assume um posto de médico do hospital Hôtel-Dieu, anteriormente pertencente a Ferrier, no qual permaneceria até 17 de Junho de 1612. Ocasionalmente, Sanches ministrava preleções sobre cirurgia quando algum professor regente da universidade estava ausente. No início de 1585 Sanches foi apontado para o cargo de professor régio de filosofia na Universidade de Toulouse, posição que ocuparia concomitantemente com suas funções médicas no Hôtel-Dieu até 1612. Neste ano, após mais duas tentativas fracassadas em 1588 e 1604, Sanches consegue o que parece ter sido sua maior ambição, a posição de professor regente em medicina, à qual Sanches se dedicou até seu falecimento em 16 Novembro de 1623.

Farta produção de estudos voltados para a medicina parece ter ocupado Sanches. Mais do que os poucos voltados para a filosofia. Isto pode ter se dado tanto por Sanches ter decido que tais estudos médicos eram mais importantes para sua prática no Hôtel-Dieu e para a pavimentação de seu caminho para a posição de professor regente universitário de medicina, quanto pelo fato de terem se

${ }^{43}$ SANCHES, F., That Nothing is Known, p.18. 
perdido os títulos filosófico aos quais se refere como prontos ou como planos para trabalhos futuros em diversas passagens de Que Nada se Sabe.

De qualquer forma, esta relativamente pouca produção filosófica pode ser dividida em dois módulos. Um essencialmente voltado para a expressão do pensamento próprio de Sanches e outro voltado para o comentário de textos aristotélicos como ferramenta pedagógica para seus cursos de filosofia em Toulouse, que só foi publicado postumamente em 1636 na edição dos trabalhos médicos e filosóficos preparada por Delassus. Estes comentários voltam-se para os textos de Aristóteles Da adivinhação pelo sonho, Physiognomicon e Da Longevidade e Brevidade da Vida. O período entre 1574 e 1581, no qual ainda não tinha uma nomeação para a função médica, é onde percebemos a imersão de Sanches na filosofia. Nele surgiram e foram publicados seus dois únicos textos filosóficos de expressão autônoma: O Cometa do Ano de 1577 (Lyon, 1578) e Que Nada se Sabe (Lyon, 1581). Na primeira, Sanches ataca fortemente as predições de desgraças humanas e catástrofes naturais que assolariam a Europa após a passagem de um Cometa acontecida em 1577. Na segunda, encontramos a importante apresentação da virulenta crítica de Sanches não somente a Aristóteles e a Platão, mas também a toda a possibilidade de uma ciência no sentido tradicional, aquele que concebe o conhecimento como o acesso direto à natureza íntima das coisas. Nesta obra, a dúvida é apontada como inexorável início e limite do caminho da busca pelo conhecimento. Na dedicatória desta obra a seu amigo, Diogo de Castro, Sanches esclarece que ela já havia sido escrita sete anos antes, o que nos faz recuar sua redação para o ano de 1574. Segundo esta dedicatória, tal obra deveria ser publicada convenientemente antes de outras para as quais ela seria introdutória. Em seu decorrer, diversas vezes são citadas as obras que Sanches planejava publicar: um tratado sobre a alma intitulado Tractatus de Anima, um tratado sobre as coisas, intitulado Examem Rerum, e um tratado sobre o método do conhecimento, intitulado Methodus Sciendi. Essas obras estão perdidas ou não foram escritas. Sabemos, no entanto, através de Que Nada se Sabe, que a preocupação filosófica de Sanches é puramente de caráter epistemológico e propedêutico ao exercício da medicina, pois é na filosofia que residem os arcanos da arte médica. A ele não interessam as minúcias filosóficas, mas sim a análise dos fundamentos da possibilidade de uma investigação 
científica, que é uma questão tratada pela filosofia, porém necessária para ciência médica.

A segunda edição de Que Nada se Sabe, em 1618, em Frankfurt, recebeu uma complementação ao seu título bastante sugestiva: De multum nobili et prima universali scientia quod nihil scitur. Contudo, não se tem certeza da autenticidade da autoria do próprio Sanches nesta complementação. Há de se apontar aqui o fato de Descartes ter estado em Frankfurt no momento desta segunda edição, o que é um indício da possibilidade de aquele que é tido com o patrono da dúvida na Modernidade ter tomado contato com a obra de Sanches e de alguma forma se inspirado no seu uso introdutório e hiperbólico da dúvida. Apesar de não nos caber aqui o estudo comparado detalhado entre os dois filósofos, as semelhanças são estonteantes. Podemos, minimamente, contudo, distingui-los pelo fato de o uso introdutório e hiperbólico feito da dúvida cética por Sanches não superar totalmente a dúvida, enquanto Descartes parece criar a dissolução absoluta de todos os saberes somente como artifício inicial, sabendo já de antemão um meio de superar a dúvida. Outros pensadores influentes certamente tiveram contato com Que Nada se Sabe, pois se referem a ele seja em sua correspondência, tal qual o faz Mersenne, ou em suas obras, como são os casos de Leibniz que ataca Sanches em seu trabalho de mestrado e de Pierre Bayle que qualifica Sanches como "um grande pirrônico" no seu Dictionnaire Historique et Critique. Apesar de parecer não ter exercido muita influência no século XVII ${ }^{44}$, o Quod Nihil Scitur de Sanches foi enumerado como parte integrante necessária de qualquer biblioteca bem apurada, por Gabriel Naudé em seu Advis pour dresser une Bibliothèque (1627). Sanches também recebeu alguns ataques vindos dos teólogos alemães Ulrich Wild em Quod aliquid scitur, publicado em Leipzig em 1664, e Daniel Hartnack em Sanchez aliquid sciens, publicado em Stettin em 1665.

${ }^{44}$ POPKIN, R. H., História do Ceticismo de Erasmo a Spinoza, p. 86. 


\section{CAP IV - O Objetivo Polêmico do Quod Nihil Scitur}

Conforme Sanches explica a seu amigo Diogo de Castro em sua dedicatória, o Quod Nihil Scitur, publicado em 1581, foi escrito sete anos antes. A intenção, porém, era de que o período de maturação desta obra fosse de nove anos, seguindo a indicação literária de Horácio. Todavia, as condições degradadas de seu manuscrito impunham ou a publicação imediata ou a sua possível perda, o que tornou necessária a sua publicação prematura. Algo que parece corroborar esta informação é a falta de sistematicidade na organização deste texto, que frequentemente anuncia um assunto, desviando-se para outro tema e posteriormente retornando. Mesmo que imatura, neste caso, há pelo menos a chance desta obra ser bem sucedida na sobrevivência assim como os bebês prematuros de sete meses o são, assim Sanches espera. Junte-se a esta razão, a intenção do filósofo de publicar outras obras posteriormente, às quais o Quod Nihil Scitur exerceria a função de antecessora: Tractatus de Anima, Examem Rerum, e Methodus Sciendi. Tais obras são citadas em algumas passagens da obra da qual nos ocupamos neste momento e como já dissemos no capítulo anterior, não se sabe se de fato chegaram a ser redigidas ou se por ventura se perderam. Caso desejasse também fazer correções no texto final, nunca terminaria esta tarefa, tal qual Sísifo eternamente rolando a pedra montanha acima, e nada chegaria a ser publicado. E, de fato, como veremos, esta rápida referência a Sísifo é muito adequada à concepção que Sanches tem sobre nossos esforços para obter conhecimentos acerca da verdade da natureza, pois esta é vista como um conjunto indeterminável de relações, às quais nossos limites cognitivos não conseguem abarcar totalmente, deixando permanentemente em aberto a nossa tarefa de sua compreensão. Deste modo Sanches justifica sua publicação.

Além deste papel propedêutico, Sanches atribui uma função bélica ao Quod Nihil Scitur, que é enviado "a campo com bons auspícios, como soldado que vai batalhar contra a mentira." $45 \mathrm{O}$ tom polêmico é frequentemente 
reafirmado, predominando em toda a extensão desta obra. Na carta ao leitor Sanches descreve o processo de desencanto que o levou à redação deste ataque e declaração de guerra às tentativas anteriores de abordagem da verdade. Desde jovem, sedento por conhecimento, Sanches buscou alimentar-se indistintamente de todos os saberes que lhe fossem oferecidos. Num certo momento, porém, tudo começou a lhe parecer indigesto. A escolha mais apurada daquilo com o qual tentava saciar o desejo de conhecer passou a ser necessária. Em sua maioria, os antigos e os contemporâneos de Sanches pareciam não lhe dizer nada. Somente alguns mostravam uma sobra da verdade, mas nenhum destes disse nada que pudesse ser tido como absolutamente certo acerca de como devemos entender as coisas. As consultas feitas aos célebres mestres da verdade resultam sempre em decepção, pois se percebe que cada um deles criou um conjunto incoerente de quimeras ao tentar estabelecer algo sólido acerca da verdade, construindo sua ciência à base de fantasias, suas e de outros, das quais outras eram inferidas, culminando na instauração de um labirinto de palavras, que mais nos afasta do que nos aproxima da realidade. "Daí os átomos de Demócrito, as ideias de Platão, os números de Pitágoras, os universais de Aristóteles, o intelecto ativo e as inteligências." $" 46$

Acrescente-se aos entraves para a busca da verdade, os defensores destes falsos conhecedores dos princípios da natureza, que recorrem, sobretudo a Aristóteles, decorando suas passagens e disputando pelo título de mais douto pura e simplesmente por saber mais passagens do grande estagirita de cor. Estes são os mesmos que classificam como sofista a todo aquele que busque contestar e seguir um caminho diferente deste mestre grego. Não que este tenha sido um pobre exemplo de mais um falso grande intelecto. Sanches é de opinião que Aristóteles teve uma das mais distintas e agudas entre as mentes humanas. Contudo, é necessário asseverar que como humano, ele também errou em alguns casos, ignorou algumas coisas e evitou outras. "Era homem como nós; e por isso

\footnotetext{
45 SANCHES, F. Que Nada se Sabe. Tradução de Basílio Vasconcelos. p. 61. In: Obra Filosófica. Tradução de G. Manuppela, B. Vasconcelos, M. P. Meneses. Lisboa: Imprensa Nacional - Casa da Moeda, 1999. p. 59 - 148. Utilizaremos este volume como base em nossas citações.

${ }^{46}$ SANCHES, F. Que Nada se Sabe, p. 64.
} 
bastantes vezes teve de pagar tributo à insuficiência e fraqueza do espírito humano." $" 47$

Tal decepção com os discursos sobre o conhecimento e a verdade impuseram a Sanches outro caminho: suspender seu juízo acerca de tudo o que se sabe, estendendo a dúvida até aos princípios das coisas, e buscar por si mesmo alguma certeza. É pesada esta escolha. Entretanto, parece ser o único caminho restante após a descoberta de toda a incerteza imputável a tudo o que se pensava saber anteriormente. Vejamos algumas palavras que indicam a opção do uso metodológico e hiperbólico da dúvida em Sanches como artifício para a análise da validade do conhecimento:

Voltei-me então para mim próprio; e pondo tudo em dúvida como se até então nada se tivesse dito, comecei a examinar as próprias coisas: é esse o verdadeiro meio de saber.

Levava as minhas investigações até aos primeiros princípios. Iniciando aí as minhas reflexões, quanto mais penso, mais duvido: nada posso compreender bem. Desespero. No entanto, persisto. ${ }^{48}$

As primeiras orientações tomadas por Sanches, igualmente recomendadas àqueles que desejam saber algo, consistem no afastamento das opiniões longamente aceitas, discutidas e reformuladas pela tradição, e no mergulho no conhecimento do mundo através de uma tentativa pessoal própria. Aquele que segue o caminho previamente pavimentado pela tradição mostra ser mais um homem de fé do que um homem da ciência. Sua servilidade e reverência aos autores do passado são mais próprias de um ânimo inculto do que de um espírito livre, que busca a verdade. "A autoridade manda crer: a razão demonstra: aquela é própria da fé; esta, da ciência" 49 Este mote da ciência livre é utilizado em outras passagens do Quod Nihil Scitur. Quando ataca a ideia aristotélica da demonstração, Sanches a destitui de sua capacidade legitimadora da ciência, e mais uma vez exalta a investigação direta das coisas em detrimento da investigação dos discursos prévios de autoridades da tradição e dos intermináveis livros que a estas se seguem tentando esclarecer e retificar os seus mestres. "A verdadeira ciência é livre e filha de espírito livre."50 "A maior parte dos letrados

\footnotetext{
${ }^{47}$ Ibid. p. 65.

${ }^{48}$ SANCHES, F. Que Nada se Sabe, p. 63.

${ }^{49}$ Ibid., p. 66.

${ }^{50}$ Ibid., p. 77.
} 
são crentes. (...) edificando assim sobre maus alicerces" "51 ao inferir qualquer coisa a partir destes elogios, que não servem de nada para uma ciência, pois são obtidos sem o uso da experiência e da razão, e a partir de bases duvidosas. Atacando as constantes retificações na doutrina silogística feitas por dialéticos, Sanches novamente se refere a esta comparação da obtenção de conhecimento com a construção de um edifício:

Fazem lembrar um velho edifício que ameaça ruína, um edifício construído sobre areia, em lugar instável, e de matéria frágil, ao qual a gente está continuamente a escorar e a por pedras, cal e coisas semelhantes, e ele continuamente a fender por todos os lados. ${ }^{52}$

A título de dar ênfase ao uso tanto metodológico quanto hiperbólico da dúvida, que não é casual ou impensado em Sanches, e de reforçar a preconização da análise autônoma das coisas por parte deste mesmo pensador, gostaríamos de citar um outro trecho que se distingue por estabelecer qual é a natureza do verdadeiro conhecimento científico, qual seja, o acesso à constituição essencial das coisas. Nele também veremos a atitude desataviada de Sanches ao expor sua opinião acerca da intransponibilidade da dúvida:

(...) logo, porém, que me voltei para as coisas rejeitando então a precedente fé, pois era mais fé que ciência, comecei a examiná-las, como se nunca por alguém alguma coisa tivesse sido dita, e aquilo que eu antes julgara saber, parecia-me agora ignorá-lo (contrariamente àquele que até à virilidade dizia ignorar tudo, e depois tudo saber), e ignorá-lo cada vez mais; e a tal ponto chegaram as coisas que me parece que nada sei, e nada espero poder saber, e quanto mais examino as coisas mais duvido. E por que não hei-de eu duvidar, se não posso perceber e conhecer a essência das coisas? Dessa é que deve ser a verdadeira ciência. É fácil realmente ver um magnete; mas o que vem a se ele? Por que atrai o ferro? Isto é que seria saber, se saber pudéssemos. ${ }^{53}$

Apesar de um estudo comparativo entre o pensamento cartesiano e o sanchesiano não ser exatamente nosso objetivo, note-se as grandes semelhanças entre ambos tanto quando descrevem o caminho que os levaram até à decepção com a tradição, quanto quando escolhem o uso da dúvida universal como ferramenta metodológica inicial frente a tal problema. Tal estudo comparativo indicaria também a utilização de pelo menos um argumento diferente para instaurar a dúvida, pois Sanches não apresenta nenhum argumento semelhante à

\footnotetext{
${ }^{51}$ Ibid., p.141.

${ }^{52}$ SANCHES, F. Que Nada se Sabe, p.137.

${ }^{53}$ Ibid., p. 144.
} 
hipótese do Gênio Maligno cartesiano, por exemplo; tal investigação comparativa entre estes pensadores também apontaria diferentes elementos dados em resposta à dúvida, pois Descartes oferece a superação da dúvida através da certeza primeira e irrefutável do Cogito, enquanto Sanches aceita um conhecimento incerto por não ver possível superação da dúvida. Descartes, devemos mencionar, apresenta tal uso da dúvida na Segunda Parte do Discurso do Método (1637) e na Meditação Primeira das Meditações (1641), décadas após a publicação do Quod Nihil Scitur. Para ilustrar melhor, vejamos uma passagem emblemática disto em ambas as obras:

(...) no tocante a todas as opiniões que até então acolhera em meu crédito, o melhor a fazer seria dispor-me, de uma vez para sempre, a retirar-lhes essa confiança, a fim de substituí-las em seguida ou por outras melhores, ou então pelas mesmas, depois de tê-las ajustado ao nível da razão. E acreditei firmemente que por este meio, lograria conduzir minha vida muito melhor do que se a edificasse apenas sobre velhos fundamentos, e me apoiasse tão somente sobre princípios de que me deixara persuadir em minha juventude, sem ter jamais examinado se eram verdadeiros. ${ }^{54}$

Há já algum tempo eu me apercebi de que, desde meus primeiros anos, recebera muitas falsas opiniões como verdadeiras, e de que aquilo que depois eu fundei em princípios tão mal assegurados não podia ser senão mui duvidoso e incerto; de modo que me era necessário tentar seriamente, uma vez em minha vida, desfazerme de todas as opiniões que até agora dera crédito, e começar tudo novamente desde os fundamentos, se quisesse estabelecer algo de firme e de constante nas ciências. ${ }^{55}$

Um argumento factual para uma possível leitura desta obra de Sanches por parte de Descartes, que não seja baseado nas semelhanças da letra e do espírito, pode ser a informação da estadia do filósofo francês em Frankfurt em 1618, mesmo ano em que foi impressa nesta cidade a segunda edição deste escrito cético do português. Outras possíveis semelhanças argumentativas entre Sanches e Descartes parecem estar no uso que ambos fazem tanto do argumento da inexperiência juvenil como fonte de julgamentos apressados e equivocados, quanto na metáfora de um edifício do conhecimento, à qual aludimos acima em duas passagens do Quod Nihil Scitur. Elaine Limbrick ${ }^{56}$ aponta que o que anima o pensamento filosófico, tanto de Descartes como de Sanches, é o desejo de encontrar um método confiável sobre o qual se possa fundar as bases indiscutíveis

\footnotetext{
${ }^{54}$ DESCARTES, R., Discurso do Método, p.35.

55 Ibid., Meditações, p.85.

56 LIMBRICK, E., Franciscus Sanchez Scepticus - Un Médecin Philosophe Précurseur de Descartes (1550-1623), p. 269 - 70.
} 
da ciência. Nestes dois pensadores a dúvida se apresentaria como um estágio inicial necessário para o espírito anteriormente à abordagem adequada do método. Deste modo, a longo prazo, tanto a dúvida cartesiana quanto a dúvida sanchesiana seriam positivas. Curiosamente, apesar de toda a ênfase em nossos limites cognitivos, que veremos no seguimento de nosso trabalho, Sanches realmente anuncia tal pretensão construtiva para seu método, que seria apresentado após o primeiro passo de caráter destrutivo e libertador exercido pela dúvida. Referindose a todas as dificuldades que apresentou, e explicando que não deseja fazer como seus adversários que se põem a explicar o incompreendido com razões ainda mais obscuras e duvidosas, Sanches anuncia ter a intenção de "fundar uma ciência firme e o mais fácil que puder, e não cheia de quimeras e de ficções alheias à verdade do assunto, e que são arranjadas só para mostrar a agudeza de engenho do escritor, e não para mostrar as coisas" ${ }^{57}$. Sabemos que Descartes, através da certeza inicial do Cogito, sustenta a pretensão de conhecer a natureza última da realidade. Tal não é o caso de Sanches, mesmo que tenha anunciado no trecho acima a pretensão de fundar um método firme e confiável. Engana-se aquele que pensa que a tal anuncio segue-se a posse de certezas absolutas, pois, ainda sobre o seu método, algumas linhas à frente nas últimas palavras do Quod Nihil Scitur, Sanches promete que, limitando-se ao estudo sobre as coisas, num outro livro, aquele sobre o método científico, dirá se e como podemos saber alguma coisa, expondo este meio tanto quanto seja compatível com a debilidade humana. Ora, fica patente, assim nos parece, que nossas possibilidades de conhecimento continuam limitadas às características secundárias das coisas, que percebemos por meios sensoriais e com o auxílio do juízo, conforme Sanches repetidamente explica ao dizer que só podemos conhecer imperfeitamente.

Outro estudioso que considera Sanches um precursor de Descartes é Joseph Moreau, o qual afirma categoricamente que "Le Quod Nihil Scitur n'est pas une profession de scepticisme" ${ }^{\circ 8}$. Este comentador cita uma passagem onde Sanches anuncia as pretensões do seu método, quais sejam, as de formar um caminho firme e fácil para conhecer algo conforme as estreitas possibilidades do débil espírito humano através do estudo das coisas. Em seguida, menciona a indicação sanchesiana de que tal método basear-se-ia no uso circunspecto da

\footnotetext{
${ }^{57}$ SANCHES, F., Que Nada se Sabe, pp. $146-47$.
}

${ }^{58}$ MOREAU, J., Sanchez, Précartésian, p. 264. 
interação entre experiência e juízo. Citando uma passagem da Carta a Cristovão Clávio, Joseph Moreau menciona a atitude cautelosa e opinião duvidosa de Sanches sobre a capacidade das matemáticas de serem ferramenta apropriada para o estudo da realidade, o que é um contraponto à atitude de confiança cartesiana nesta mesma possível ferramenta cognitiva. Que se nos permita aqui mais uma citação, com o intuito de ilustrar textualmente o caráter metódico e hiperbólico da dúvida sanchesiana:

Buscando eu, outrora, a verdade através da Física e da Metafísica, sem jamais a poder descortinar, alguém me disse ter ela estabelecido o seu poiso entre as coisas naturais e as transnaturais, isto é, na Matemática. Ávida e alegremente acorro; (...) logo ao pôr os pés no átrio das Matemáticas, hesitei, temendo, de todos os lados, desconfiado e suspeito, o dolo. As vantagens foram palpáveis. Sem essa desconfiança, teria caído em terreno minado, qual é o que se cava no campo da Matemática, não tão grande e vasto como no da Física e da Metafísica, mas por isso mesmo mais difícil e perigoso. ${ }^{59}$

Isto, assim nos parece, reforça a opinião de uma tomada do ceticismo como postura mais apropriada por parte de Sanches. Tendo tais dados em nosso horizonte de análise, torna-se estranho o fato de Moreau destituir a posição final de Sanches no Quod Nihil Scitur de uma tendência cética. O comentador parece considerar que a mitigação do ceticismo que podemos perceber em Sanches, através da aceitação de uma ciência imperfeita que não tem acesso à natureza das coisas, é um indício da assunção de algo parecido com a postura cartesiana que utiliza a dúvida hiperbólica e metodologicamente apontando posteriormente para um conhecimento absolutamente certo sobre a natureza das coisas. Somos de opinião contrária, pois a aceitação de uma ciência dos acidentes, e não das essências, não parece nos indicar a superação do ceticismo em Sanches. Parece, sim, uma concessão ao ceticismo que, não podendo ser ultrapassado, nos limita a este âmbito cognitivo secundário, do conhecimento inseguro através dos sentidos e do juízo, sem que tenhamos certeza nem mesmo sobre as imagens que nos chegam através dos duvidosos meios sensoriais.

O quinhão positivo que podemos deduzir do Quod Nihil Scitur é associado por Moreau à distinção encontrada no estoicismo de Zenão entre a representação que temos de um objeto e o nosso juízo acerca desta representação. Joseph

59 SANCHES, F., Carta a Cristovão Clávio. Sem indicação de tradução. pp. 263 - 264. In: SANCHES, F., Obra Filosófica. Imprensa Nacional - Casa da Moeda, 1999. pp. 261 - 274. 
Moreau não cita, mas tal distinção está também na base da refutação de Arcesilau a Zenão, à qual já nos referimos no primeiro capítulo. Tal bipartição, não podemos esquecer, questiona consequentemente a diferença entre nossa representação e o objeto representado que está fora de nosso pensamento. Isto, conjuntamente com a dúvida, é condição para a suspensão dos juízos. No caso de Zenão, sabemos, a dúvida não era insuperável como é no caso de Arcesilau e de Sanches. Estes dois últimos, claramente optaram, então, pela suspensão acerca do conhecimento do que é imutável na natureza última da realidade. Por nossa parte, acreditamos poder aproximar Sanches de outro cético acadêmico, Carnéades. Este, conhecido como o mais notável argumentador in utranque partem da academia cética, oferece semelhanças com Sanches tanto no tipo de argumentação, quanto na solução suspensiva e no tipo de saber incerto que nos resta, dada a força indestrutível da dúvida sobre nossas tentativas de conhecer a realidade. Esta aproximação será abordada adiante.

Tanto Sanches quanto Descartes são herdeiros desse problema existente desde Zenão. Curiosamente, ambos os pensadores modernos encontram-se novamente, em alguma medida, no trato relativo a este problema. Frente à dúvida, Descartes apresenta o Cogito, que consiste no indubitável e imediato estabelecimento da existência interior do sujeito pensante toda vez que duvida de algo. Este é o primeiro passo firme de Descartes, pois considera mais fácil a certeza imediata acerca da sua intimidade, apesar das dificuldades para conhecela, do que o problemático conhecimento e a certeza do mundo exterior. Sanches, por sua parte afirma que "sob o ponto de vista da certeza, o conhecimento que temos das coisas externas por meio dos sentidos é vencido por aquele que temos das coisas que existem em nós, ou são feitas por nós". ${ }^{60}$ Vemos Sanches, assim como Descartes, distinguindo entre certeza e conhecimento. Gianni Paganini acredita que esta volta sobre si mesmo, sem o auxílio das representações dos objetos externos, é "a pré-história do Cogito, antes de suas formulações maduras no Discurso e nas Meditações." ${ }^{1} 1$ Além disso, ao estabelecer que a certeza sobre nossas percepções interiores é maior que nossa compreensão destas, Sanches parece anunciar a maior certeza que nos cabe: a certeza de si mesmos. E,

\footnotetext{
${ }^{60}$ SANCHES, F., Que Nada se Sabe, pp. 113-114.

${ }^{61}$ PAGANINI, G., Skepsis: Le debat des Modernes sur le Scepticisme. p. 324. Tradução nossa.
} 
inversamente, ao estabelecer que nossa compreensão do mundo externo, que é imperfeita e superior à compreensão de nós mesmos, não nos oferece a devida certeza sobre este mundo, Sanches parece indicar uma certa insegurança acerca não da compreensão da constituição do mundo, mas sim da sua existência. Este novo dado, nos parece mais um argumento para a instauração da dúvida universal no pensamento de Sanches, além de poder apontar alguns caminhos para um estudo comparativo entre Sanches e Descartes.

O Quod Nihil Scitur, este soldado combatente da mentira, é enviado por Sanches ao campo de batalha com a bandeira da incerteza hasteada contra as verdades precipitadas que se apresentam com ar de convencimento retórico, silogístico, poético e filosófico. É isto o que depreendemos das palavras iniciais do texto do Quod Nihil Scitur. Numa atitude muito semelhante àquela dos céticos antigos, Sanches parece buscar a instauração inicial da suspensão dos juízos através da apresentação da ambiguidade acerca da proposição que nomeia sua obra e da impossibilidade de solução do problema que tal proposição apresenta. Qual seja, que se a proposição é verdadeira, então tudo é duvidoso, tendo como consequência a dúvida sobre esta proposição mesma; e se ela não puder ser provada, então Sanches também terá razão, pois diz não saber nem se nada sabe. Note-se que a incerteza se instala não somente por total desconhecimento sobre o valor desta proposição, mas também pela consideração da sua possível validade, que é conjectural e tem resultado dúbio. Esta aceitação, através da possível maior plausibilidade de uma proposição, nos parece próxima da postura cética dos acadêmicos, adeptos do uso ativo de crivos, que indicam a possibilidade de certeza sobre algo como saída da dúvida, diferentemente dos céticos pirrônicos, que usam a aceitação passiva das aparências como resposta ao impasse cético. Sem mais, vejamos as palavras de Sanches acerca da sua bandeira de guerra, diversas vezes repetida durante esta obra:

Nem sequer sei que não sei nada; conjecturo, porém, que nem eu nem os outros. De lábaro me servirá essa proposição, à qual se seguirá estoutra: nada se sabe. Se eu a souber provar, com razão concluirei que nada se sabe; se não souber, tanto melhor, pois isso afirmava eu. Dirás talvez: se souberes provar, seguir-se-á o contrário, visto que já sabes alguma coisa. Não: antes de tu arguires, já eu tinha concluído contra. Já começo a embrulhar o assunto, e disso mesmo se segue que nada se sabe. $^{62}$

${ }^{62}$ SANCHES, F., Que nada se Sabe, p. 67. 
Parece-nos patente agora a crise cética na qual se insere o pensamento de Sanches. Sobre suas matrizes, ainda discutiremos isso ao longo deste estudo. Por hora, seria interessante mencionar a figura de Sócrates, que também é diversas vezes citada num tom de admiração com os adjetivos, por exemplo, de "sábio e justo varão", tido como "doutíssimo" por só saber que nada sabia. ${ }^{63}$ Esta postura levou o sábio mestre de Platão a não deixar nenhum escrito, o que, admite Sanches, também lhe pareceu como uma postura atrativa para si mesmo. Esta é certamente uma outra fonte do pensamento sanchesiano, tendo em vista o fato de Sócrates, na medida em que apresentou alguns dos argumentos reunidos pelos céticos, ser considerado um dos precursores do ceticismo, até mesmo pelos textos céticos da antiguidade que nos restaram. No entanto, a pura afirmação da ignorância ainda não satisfaz o espírito de Sanches, pois assim como no caso de Sócrates, esta afirmação é ignorada. Apesar de, neste mesmo trecho, reafirmar que concebe tudo como suspeito, Sanches quer livremente seguir este caminho para deixar a pretensão de algum dia possuir a verdade. Como médico, Sanches admite precisar, em alguma medida, de pontos de apoio para suas pesquisas em medicina, sendo de opinião que ao tratar destas questões filosóficas de princípios poderá, consequentemente, com mais facilidade entender os mecanismos de nossas apressadas afirmações sobre a verdade e evitá-los. Sanches admite que algumas minúcias talvez sejam deixadas de lado ao se tratar somente dos princípios, esperando poder abarcar sub-repticiamente os outros conceitos que deles advêm. De outra forma, perdido nas infindáveis minúcias metafísicas e discussões sobre quem possui a verdade, a vida não chegaria a nada. Além do mais, o caminho pelo qual Sanches deseja pautar sua função médica vem da própria medicina, à qual, como dissemos, a discussão filosófica seria a responsável por fornecer os princípios. ${ }^{64}$ Nossa intuição é que Sanches adota, em alguma medida, a solução cética acadêmica para a dúvida, aquela da filtragem e aceitação do plausível como saída prática e intelectual da incerteza. Sobre isto, mais adiante forneceremos alguns argumentos. Apesar de fugir ao nosso domínio filosófico, talvez um estudo acerca da postura assumida por Sanches em suas obras médicas poderia nos servir como outra ferramenta para a formulação de uma hipótese mais completa acerca de como se daria o método sanchesiano de pesquisa da natureza, dado que a obra

\footnotetext{
${ }^{63}$ SANCHES, F., Que nada se Sabe, pp. 74 - 75.

${ }^{64}$ Ibid., pp. $65-66$.
} 
na qual exporia tal método, Methodus Sciendi, está perdida ou não chegou a ser escrita. Elaine Limbrick ${ }^{65}$, no estudo introdutório publicado conjuntamente com a tradução inglesa de Quod Nihil Scitur afirma que os estudos médicos de Sanches lhe proporcionaram o contato com o galenismo, e partindo daí ele inicia a sua própria busca pelo método adequado para o conhecimento, considerando a ênfase galênica na observação empírica e na experimentação, necessárias à prática médica. A relação próxima entre ceticismo e medicina também é apontada como um possível caminho fecundo de análise da obra de Sanches por Rui Bertrand Romão, que além de se propor futuramente executar tal tentativa, chega a afirmar que "na realidade, o cepticismo antigo é-nos impensável sem lhe associar de uma ou de outra maneira à medicina." ${ }^{66}$ Este estudioso aponta no empirismo médico, escola que valoriza os fenômenos e critica as predefinições racionais, à qual o próprio Sexto Empírico aderiu, o ponto de contato entre Sanches e a medicina cética dos antigos. Segundo Romão, a obra de Sanches seria um ponto de convergência entre o movimento cético antigo e a medicina neo galênica do Renascimento.

Ian Mclean fez um estudo onde tenta mostrar que além dos textos de Sexto Empírico, Cícero e Diógenes Laercio, a obra de Galeno, em especial o De optimo docendi genere, também teve sua parte na formação do ceticismo e da ciência na Modernidade $^{67}$. Esta obra de Galeno já havia sido traduzida para o Latim em 1345 por Niccolò da Reggio, mesmo que não tenha sido muito discutida entre os médicos medievais. Erasmo de Rotterdam também a traduziu, juntamente com outros dois textos de Galeno também voltados para a pedagogia: Exhortatio ad bonas arteis praesertim medicinam e Qualem oporteat esse medicum. As três foram publicadas em Paris e na Basiléia em 1526. Posteriormente, e de maneira oportuna, De optimo docendi genere foi inserida como apêndice nas duas primeiras edições das obras de Sexto Empírico em 1562 e 1569. Nesta obra Galeno ataca o ceticismo de Favorino, seu contemporâneo, que ensinava a prática cética acadêmica de argumentação advogando sobre ambas as partes como a melhor preparação que podemos ter. A crítica ao ceticismo encontrada aqui é menos ilustrativa do que as informações sobre os tropos céticos e o ataque à

${ }^{65}$ Ibid., p. 25.

${ }^{66}$ ROMÃO, R. B., Juízo e Incerteza em Francisco Sanches, pp. 55.

${ }^{67}$ MACLEAN, I., The "Sceptical Crisis" Reconsidered: Galen, Rational Medicine and the Libertas Philosophandi. In: Early Science and Medicine, Vol. 11, No. 3 (2006), pp. 247-274. 
demonstração, aos critérios, aos signos, às causas, ao movimento etc, que encontramos, por exemplo, em Diógenes Laercio, que era amplamente conhecido no momento das publicações da obra de Sexto. Maclean cita, no entanto, somente três exemplos de uso feito por médicos deste texto de Galeno: Jean Hucher, um aluno de medicina da Universidade de Montpellier, que em 1567, em sua Pro philosophica Monspeliensis Academicae libertate, parece copiar a definição de pirrônicos e acadêmicos contida no texto de Galeno; Sanches, que como já dissemos, também esteve nesta universidade, e cita esta obra de Galeno; em terceiro lugar, dois doutores, Sébastien de Monteux, em Paris em 1530, e Theodorus Collado, em 1615, que se opõem à argumentação in utramque partem por não levar à adesão a nenhuma das partes. Como já anunciamos previamente, nos interessam mais, no entanto, as principais fontes céticas propriamente filosóficas às quais sabemos que Sanches teve acesso, ou pode ter tido.

Esta obra específica de Galeno é citada por Sanches conjuntamente com o livro IX das Vidas e Doutrinas dos Filósofos Ilustres de Diógenes Laercio e o Contra Colotem de Plutarco em uma nota marginal ao texto do Quod Nihil Scitur. Neste contexto Sanches afirma que a sabedoria socrática, consistente na constatação de sua ignorância, também era afirmada pelos "chamados pirrônicos, acadêmicos e cépticos, juntamente com Favorino." ${ }^{\prime 68}$ Além desta, outras obras de Galeno são citadas por Sanches. Esta citação acima, especificamente, é interessante pelo seu contexto e pela associação com outras fontes céticas da antiguidade.

Curioso é o fato de Sexto Empírico, a referência cética mais completa e já disponível em Latim, não ser citado uma vez se quer. Cícero é mencionado algumas vezes, mas sempre tendo suas habilidades retóricas como o motivo da menção, nunca sua postura cética ou a sua obra Academica. ${ }^{69}$ Como dissemos

${ }^{68}$ SANCHES, F., Que nada se Sabe, p. 74.

69 Apesar da atmosfera cética que toma conta de toda a extensão do Quod Nihil Scitur, poucas vezes palavras-chave diretamente ligadas ao ceticismo são mencionadas. Na p. 74, como já citamos, acerca da ignorância socrática, "pirrônicos", "acadêmicos" e "céticos" são mencionados, e uma nota marginal ao texto nos remete a De optimo docendi genere de Galeno, ao livro IX das Vidas dos Filósofos Ilustres de Diógenes Laercio e ao Contra Colotem de Plutarco. Na p. 79, numa nota marginal atribui-se a visão de que tudo é inapreensível aos "acadêmicos", aos "pirrônicos" e a Xenófanes, tendo como referência textual novamente o livro IX de Diógenes Laercio e o Contra Colotem de Plutarco, além do Lucullus, também de Plutarco. Na p. 101, Sanches menciona os "pirrônicos" junto de Epicuro e Demócrito atribuindo a estes terem notado o caráter pouco esclarecedor dos acidentes. Desta vez os livros IX e X de Diógenes Laercio são citados, e novamente o Contra Colotem é mencionado. Estas três últimas referências aos capítulos 
anteriormente, apesar de estar disponível em várias edições, tal obra não tinha grande prestígio em relação às obras retóricas e políticas de Cícero, mas este autor foi parte da formação de Sanches em sua educação no Collège de Guyenne. O que pode nos levar a acreditar na possibilidade de Sanches ter conhecido o Academica. Limbrick, na nota 44 da página 184 da tradução inglesa de Quod Nihil Scitur afirma que Sanches certamente leu o texto cético de Cícero, pois a exposição da ignorância socrática (contida em Academica, I. 4) parece ter sido copiada por Sanches neste trecho de sua obra.

Quanto a Sexto Empírico, podemos igualmente conjecturar que o tenha conhecido por razões indiretas, tais como ter vivenciado o ambiente crítico e aberto ao ceticismo do Collège de Guyenne, onde ensinou Hervet, o tradutor de Adversus Mathematicos, mesmo que alguns antes da passagem de Sanches por esta instituição; e pelos estudos de cerca de três anos feitos na Itália numa época em que o ambiente cultural também era propenso à influência dos textos céticos, como mostramos anteriormente. Pode ser que a edição do De optimo docendi genere à qual Sanches teve acesso seja uma das edições nas quais esta obra foi publicada em conjunto com as traduções de Sexto Empírico, o que também indicaria a probabilidade do contato de Sanches com Sexto. Joaquim de Carvalho $^{70}$ sugere que o estilo do Latim e parte dos argumentos de Sanches são derivados da tradução de Sexto feita por Estienne. Tal opinião é citada por Richard Popkin ${ }^{71}$ para justificar a possível e dificilmente demonstrável dívida cética de Sanches com Sexto, além das semelhanças com Arcesilau e Carnéades. Porém, Popkin diz que estas semelhanças com os céticos acadêmicos poderiam ser explicadas via Cícero e Diógenes Laercio. No primeiro caso, sim. Mas no segundo, temos nossas dúvidas, pois em Diógenes Laercio não se encontram referências que caracterizem devidamente o pensamento cético nem de Arcesilau nem Carnéades, mas somente dados biográficos. Sobre Arcesilau, Sanches tem farto material cético a partir do Contra Colotem de Plutarco, rica fonte de informação neste caso e diversas vezes citado no Quod Nihil Scitur. Há ainda o Lucullus de Plutarco, que também é citado por Sanches, em uma das poucas vezes

IX e X de Diógenes Laercio e ao Contra Colotem de Plutarco são repetidas na p. 119 também em uma nota marginal, onde Sanches cita "pirrônicos", Demócrito e Epicuro como responsáveis por terem afirmado que os sentidos são dubitáveis, pois a posição dos olhos pode modificar as cores percebidas.

${ }^{70}$ SANCHES, F., Opera Philosophica., pp. LVII - LIX.

${ }^{71}$ POPKIN, R., História do Ceticismo de Erasmo a Spinoza, pp. 84 - 85. 
em que se refere a pirrônicos e acadêmicos e à exposição que estes fazem da inapreensibilidade. Contudo, os pirrônicos não são mencionados por Plutarco nesta obra. Há somente referências à Nova Academia, representada por Carnéades e seu grande defensor na época, Philo, do qual Cícero, também citado, foi discípulo. Plutarco menciona ainda a Velha Academia, dirigida por Antiochus de Ascalon, de quem Lucullus se tornou amigo e a quem levou a opor-se a Philo. Em nenhum momento as doutrinas citadas são explicadas por Plutarco. Neste caso, nos parece desapropriada a citação de Sanches, dada a falta de material condizente com o tema que tratava no texto citado. Haveria a possibilidade de este ser um erro tipográfico, e o Lucullus em questão ser o segundo livro do Academica de Cícero? Se sim, este seria um argumento para dizer que Sanches conheceu o ceticismo acadêmico através de Cícero.

Bernard Besnier ${ }^{72}$ aponta como possível justificativa para o contato de Sanches com Sexto o fato de o filósofo português decompor seus argumentos contra a sua própria noção de ciência conforme os problemas que atingem o objeto, o cognoscente e o meio do conhecimento, semelhantemente à divisão feita por Sexto Empírico acerca do critério nos capítulos V, VI e VII do segundo livro das Hipotiposes. Este é um caminho que nos parece aceitável e que posteriormente tentaremos seguir. De qualquer forma, parece-nos difícil afirmar categoricamente, através de dados biográficos ou características argumentativas, se Sanches teve ou não acesso às duas principais fontes antigas sobre o ceticismo, às quais não citou. Talvez esta falta de precisão e fidelidade à citação das suas fontes poderia ser entendida como parte da postura sanchesiana de não prestar reverência a pretensas autoridades.

É a outros espíritos livres que o Quod Nihil Scitur se destina. Assim se expressa o filósofo e médico: "Quero-me com aqueles que, não se tendo obrigado a jurar nas palavras de um mestre, examinam com os recursos próprios as questões, levados pelos sentidos e pela razão." 73 À acusação pelo possível caráter excessivamente pretensioso desta proposta, já que nega todos os grandes perscrutadores da natureza anteriores, Sanches responde que pretende apenas ser mais um que tenta se aproximar da verdade e que tem consciência de que, neste caso, uma aproximação é tudo que nos é acessível. Sanches sabe que sendo

\footnotetext{
${ }^{72}$ BESNIER, B., Sanchez à Moitié Endormi, pp. 105 - 106, nota 12.

${ }^{73}$ SANCHES, F., Que Nada se Sabe, p. 64.
} 
unívoca e tendo sido diversas vezes assediada sem ser completamente acessada, a verdade apresenta-nos à nossa humilde condição de persistentes, corruptíveis e limitados exploradores. Por isto ele adverte o leitor:

Além disso, eu não te prometo inteiramente a Verdade, visto que a ignoro, assim como a tudo o mais: procurá-la-ei, no entanto, até onde puder; e tu, descoberta que seja e expulsa dos seus esconderijos, segui-la-ás. Nunca esperes, porém, apossar-te dela, ou retê-la cientemente: basta-te o que para mim é suficiente, agitá-la. É esse o meu escopo: deve ser também o teu. ${ }^{74}$

Tal uso livre de nossos sentidos e juízos, somado à aceitação de um conhecimento incerta, nos remetem à proposta dos céticos acadêmicos. Esta aproximação, sim, é um de nossos objetivos neste estudo, onde visamos aproximar Sanches dos céticos pirrônicos e acadêmicos, no que diz respeito ao uso da argumentação cética antiga que procede pelo estabelecimento de contra argumentação a todo argumento apresentado, seguindo até à suspensão dos juízos; e dissociar Sanches dos pirrônicos, aliando-o aos acadêmicos no que tange à resposta dada à impossibilidade universal de certeza frente ao quadro resultante da utilização da argumentação cética, neste caso, optando por um processo ativo de depuração das informações, sempre rondado pela dúvida cética, de modo que só se adquire um saber imperfeito da realidade.

Ao tecer uma diferenciação entre os filósofos céticos da Academia e os outros filósofos dogmáticos, em $A c$, II, 8-9, Cícero diz que estes não questionam a validade do conhecimento que acreditam possuir, enquanto os acadêmicos sustentam diversos pontos de vista como persuasivos, não absolutamente certos, aos quais os céticos podem aderir sem, no entanto, poderem afirmá-los como verdades inquestionáveis. Sendo esta aproximação à verdade a opção resultante do seu efetivo método de análise da validade das opiniões, isto é, a argumentação advogando em ambas as partes de uma questão. Apesar da aparência inapropriada e inconclusiva, tal método é o que possibilita os acadêmicos a posse da liberdade de seus juízos, algo do qual os filósofos dogmáticos são apartados, tendo em vista que trabalham sobre duas grandes limitações. Primeiramente estão acorrentados a noções recebidas em sua educação inicial, tão fortemente assentadas, que se tornam dificilmente questionáveis, mesmo que tenham sido adquiridas no momento em que não estavam aptos para julgar nada apropriadamente, dada a sua

${ }^{74}$ SANCHES, F., Que Nada se Sabe, p. 65. 
incapacidade inicial de julgar o que é ou não consistente. Em segundo lugar, são obrigados a defender os pontos de vista de um mestre, o qual julgam ser sábio seja após ouvirem um único discurso deste mestre ou pela pressão de um amigo, aceitando tais pontos de vista antes da difícil, mas necessária, tentativa de julgar por si próprios qual visão é mais bem sustentada. Tal postura causa estranhamento em Cícero, pois como poderia alguém que não é sábio ter razão em julgar outrem como sábio? Assim, os céticos acadêmicos seriam mais livres, pois preferem manter sua capacidade de julgamento insubordinada a toda autoridade, o que lhes poupa de serem impelidos à obrigação da reverência e da defesa de opiniões a prescritas e praticamente impostas por outros. ${ }^{75}$ Esta liberdade é utilizada através do método de argumentação in utramque partem que, mesmo que possa ser contestado pelos dogmáticos, permite que os estudantes "sejam guiados pela razão, ao invés da autoridade" ${ }^{76}$, tal como fica explícito em Ac, II, 60.

Ora, encontramos inúmeras passagens de Sanches onde há uma crítica semelhante a esta encontrada em Cícero. Boa parte do Quod Nihil Scitur se dedica a explicitar o caráter indevido e pouco esclarecedor presente no ato de adesão à maioria das opiniões. Uma passagem bastante expressiva acerca deste problema apresenta o dilema de um jovem aprendiz, inexperiente, que precisa escolher por onde começar seus estudos e a quem fiar confiança na condução destes. Este estudante, caso seja livre, tem a opção de não se sujeitar a nenhum mestre ao invés de obrigatoriamente filiar-se a uma escola qualquer. Porém, ambas as opções são incertas, pois em tudo há engano e miséria. De qualquer maneira, frente a este dilema, Sanches ainda opta pela opção da liberdade, pois:

Se se entregar todo a algum, torna-se, não instruído, mas escravo; e os princípios desse defendê-los-á o mais possível e por todos os meios. (...) o nosso jovem perece com a sua ciência sempre que se prende pertinazmente a alguém, pois não é sem prejuízo da verdade que alguém pode jurar na palavra do mestre. Acreditar igualmente em todos, e igualmente em nenhum, para tirar de todos o que the parecer melhor, é mais livre, porém mais difícil. ${ }^{77}$

O destronamento da autoridade e a difícil, porém mais apropriada, opção de guiar racionalmente seus próprios juízos, conforme propõe Sanches aparece agora muito mais claramente semelhante à mesma postura de Cícero. Na mesma

\footnotetext{
${ }^{75}$ CICERO, M. T., On Academic skepticism, pp. 6 - 7. Ac, II, 8 - 9.

${ }^{76}$ Ibid., p. 36. Ac, II, 60. Tradução nossa.

${ }^{77}$ SANCHES, F., Que Nada se Sabe, p. 135.
} 
página da passagem acima Sanches chega a dizer, em nota marginal ao texto, que "O principiante não deve escravizar-se a ninguém".

Entretanto, há em Sanches o apelo à investigação da realidade como oportunidade mais apropriada de saber algo cientificamente, ao invés do debruçarse eterno sobre as intermináveis opiniões preestabelecidas pelos célebres sábios da tradição. Os mais velhos, por exemplo, são julgados mais aptos para o governo de um país e a experiência é tida como aquilo que faz um homem mais douto e prudente $^{78}$. Este apelo à experiência própria, livre dos relatos anteriores sobre a natureza, não nos parece explicitamente presente no texto de Cícero. Como já dissemos, esta nos parece uma opinião vinda de Galeno.

Nos parece igualmente sensato supor que esta postura venha de um espírito comum à época de Sanches, que é marcada pelos descobrimentos feitos pelas Grandes Navegações, às quais Sanches se refere quando trata dos problemas relativos ao conhecimento dos objetos. Em duas curtas passagens, o pensador português comenta as consequências das descobertas na América para nossa visão sobre a constituição geográfica do mundo e sobre o ser humano. No primeiro trecho, a descoberta do Novo Mundo é tida como argumento que nos obriga a abandonar as opiniões anteriores de que só havia um oceano, três continentes, do caráter de inabitável que atribuíamos à região meridional do Equador por causa do calor e dos Polos por causa do frio. ${ }^{79}$ A segunda passagem se dá durante o comentário sobre a sucessão das opiniões percebida na história, pela qual mestres são erguidos por uma época num certo lugar, e posteriormente, na mesma região, perdem tal poder de convencimento, sendo esquecidos. A visão etnocêntrica dos europeus em relação aos indígenas, comum no momento das Descobertas, é explorada por Sanches como artifício para questionar a visão europeia que atribuía, baseando-se claramente no modo de vida europeu, certa incapacidade de humanização aos habitantes das novas terras: "Quanta ignorância não reinou até aqui entre os Índios! E agora vão se tornando mais astutos, religiosos e doutos do que nós." ${ }^{\circ 0}$ Sanches é um dos primeiros pensadores a utilizar com um ar cético os novos conhecimentos apresentados pelas Grandes Navegações.

\footnotetext{
${ }^{78}$ SANCHES, F., Que Nada se Sabe, p. 141. Em nota marginal ao texto.

${ }^{79}$ Ibid., p. 99.

${ }^{80}$ Ibid., p. 135.
} 
Montaigne também o fez. O ensaio intitulado Dos canibais é o capítulo dos seus Ensaios onde se trata especificamente das questões levantadas pelas novidades trazidas da América. Conforme Danilo Marcondes, ${ }^{81}$ este fato histórico que precede cronologicamente Revolução Científica e a Reforma Protestante, os outros dois acontecimentos comumente apontados como determinantes para a formação do pensamento Moderno, insere-se no mesmo contexto de discussão conceitual que leva à ruptura com toda a tradição, da Antiga até à Medieval. O aspecto fundamental da problemática advinda deste contexto das Navegações é nomeado por este comentador como "argumento antropológico", na medida em que os contrastes até então desconhecidos entre europeus e americanos nos questionam: "Haveria uma natureza humana universal? E de que critérios dispomos para definir 'natureza humana' diante da diversidade de culturas que aí se encontram?"82 A princípio, pode-se pensar que tal "argumento antropológico" já se encontraria subsumido pelos casos propostos em dois dos Tropos de Enesidemo. Estes são, seguindo a exposição de Sexto Empírico, o oitavo Tropo, aquele referente à relatividade, e o décimo Tropo, aquele referente às diferenças entre costumes, leis e crenças. Porém, após uma abordagem mais precisa, percebese que nenhum destes tropos instaura diretamente o questionamento acerca da natureza humana, apesar de considerarem que devemos suspender os juízos com base no fato de que todo julgamento é relativo a quem julga e às condições de quem julga. O uso antropológico feito por Montaigne do acontecimento das descobertas parece realmente apresentar um novo questionamento, que não estava presente nem em Sexto Empírico, nem em Sanches. De qualquer forma, o uso feito por Sanches deste fato histórico não perde seu caráter iconoclasta e ainda nos parece como algo notável, pois ele teve a percepção do potencial cético contido neste acontecimento tão marcante, que lhe serviu como mais um motivo, vindo da experiência, para reforçar a necessidade de nossa abertura para o novo, em detrimento dos enquadramentos preestabelecidos que utilizamos para entendermos as coisas. Esta é uma das lições que o ensaio Dos Canibais tem para nos oferecer, conforme Marcondes.

\footnotetext{
${ }^{81}$ MARCONDES, D., Montaigne, a Descoberta do Novo Mundo e o Ceticismo Moderno. In: Kriterion: Belo Horizonte, no 126, Dez./2012, p. 421 - 433.

${ }^{82}$ Ibid., p. 423.
} 
Outros comentadores também se referem às descobertas e associam Sanches ao uso deste acontecimento. Artur Moreira de Sá, em seu prefácio para sua seleção de textos de Sanches, nos conta que no momento das expansões e das atividades marítimas em Portugal havia uma tendência cultural diferente da longa tradição escolástica. Esta pode ser designada como um "pragmatismo vivido", conforme expressão que de Sá empresta do Prof. Vieira de Almeida. Assim já havia a tendência de buscar pela experiência própria desmistificar os conceitos que pretendiam direcionar o conhecimento a partir de fora da experiência. De Sá conta que a curiosidade levava as pessoas não só aos escritos dos viajantes, publicados ou não, mas também ao Cais da Ribeira das Naus quando chegava algum barco vindo das novas terras. ${ }^{83}$ Sabemos que enquanto viveu em Portugal, até mais ou menos seus 11 anos, Sanches não viveu exatamente próximo ao mar. Mas tal espírito de curiosidade e espanto com as descobertas tomou a Europa, inclusive a França, onde Sanches continuou sua educação, mesmo país de origem de Montaigne. Onésimo Teotónio Almeida aponta que, bem antes do que costumamos aceitar, ainda no período dos Descobrimentos, a importância fundamental da experiência foi tomada como valor essencial. ${ }^{84}$ Maria José Cantista, por sua vez, explica que este apelo à experiência, partilhado pelo espírito português, ainda não tinha a mesma constituição percebida na experiência exaltada pela Revolução Científica do século XVII. Cantista explica que a experiência preconizada pela Revolução Científica poderia ser mais apropriadamente expressa como uma experimentação programada e controlada, sistemática e metódica, utilizada como base do conhecimento científico, indo além de um saber empírico aleatoriamente adquirido e advindo da vida $\operatorname{cotidiana}^{85}$. Pelo menos a Sanches, temos a intuição, a sua educação em medicina, com orientação enfatizada no empirismo médico de Galeno, e a sua estadia para estudos no grande centro de experimentação que era a Itália renascentista, podem ter-lhe ensinado esta forma ordenada de observar a experiência.

Vimos que Sanches interdita nossas possibilidades de um conhecimento da natureza última da realidade e destitui de validade o pensamento tanto dos antigos

${ }^{83}$ SÁ, A. M. de, Francisco Sanches, pp. $11-13$.

${ }^{84}$ ALMEIDA, O. T., Francisco Sanches - o "Elo Perdido" entre os Descobrimentos e a Ciência Moderna, p. 222.

${ }^{85}$ CANTISTA, M. J., Crítica do Saber Tradicional e Cepticismo na Época dos Descobrimentos: A Obra de Francisco Ribeiro Sanches (1551 - 1623), p. 122. 
como dos seus contemporâneos. Os argumentos utilizados para isso são diversos: ataques à autoridade dos sentidos, da racionalidade, dos sábios antigos e contemporâneos. Em contrapartida, ainda que nos faltem as obras onde pretendia expor a parte construtiva de seu método, nos restam pistas gerais de que a partir da experiência e do juízo podemos conhecer algo, mesmo que secundário e incerto, conforme permitam os nossos limites. Sustentamos que Sanches, apesar de utilizar o ceticismo metodológica e hiperbolicamente, não deixa a sua postura cética. Pelo que vimos, ele aproxima-se daquilo que Popkin chamou de Ceticismo Mitigado ou Construtivo, no capítulo VI de sua História do Ceticismo. Além das constantes afirmações de que nada se sabe acerca dos arcanos da natureza, e das frequentes reiterações de seu desejo de estabelecer tal dúvida como meio de livrar-nos dos entraves que são as opiniões já disponíveis, há algumas passagens onde Sanches relata o profundo desolamento em que se encontra por causa da incapacidade de superação da dúvida.

Efetivamente, se eu conhecesse bem alguma coisa, não o negaria, antes, de contentamento, o proclamaria bem alto, pois nada melhor me podia acontecer; sou, porém, atormentado por uma perpétua tristeza, desesperando de poder conhecer bem alguma coisa. ${ }^{86}$

O fim dos nossos estudos, o prêmio de um trabalho vão e inútil, são as perpétuas vigílias, a fadiga, os cuidados, a inquietação, a solidão, a privação de todas as delícias, a vida semelhante à morte, vivendo, combatendo, falando, pensando com os mortos, separar-se dos vivos, descurar os próprios bens, e destruir o corpo apurando o espírito. Daqui as doenças, muitas vezes a loucura, e sempre a morte. E se o trabalho ímprobo vence todas as coisas, é porque tira a vida, e apressa a morte que de todas as coisas nos livra, e assim aquele que morre vence tudo. ${ }^{87}$

Estas não nos parecem as palavras de alguém que está confiante de encontrar diretrizes seguras. A dureza e o tamanho desespero destas palavras nos lembram das palavras de David Hume no Tratado da Natureza Humana. Buscando sustentar a dúvida e julgando a todos como ignorantes, incluindo a si mesmo como alguém que não pode dizer coisas isentas de suspeitas, poderíamos perguntar a Sanches: qual a razão de continuar a pesquisar e escrever? O mesmo responderia: "Com os parvos, sê parvo; sou homem: o que fazer?" 88

\footnotetext{
${ }^{86}$ SANCHES, F., Que Nada se Sabe, pp. 105 - 106.

${ }^{87}$ Ibid., p. 107.

${ }^{88}$ Ibid., p. 86.
} 
Em seguida, trataremos das críticas feitas no Quod Nihil Scitur a Platão, Aristóteles e à noção de ciência erigida pelo próprio Sanches. Nestes casos teremos a oportunidade de desenvolver ainda mais o caminho que traçamos para sustentar que Sanches desenvolve uma dúvida metódica, hiperbólica e insuperável, tomando para si uma postura cética mitigada, de modo semelhante ao apresentado pelo ceticismo acadêmico de Carnéades. 


\section{CAP. V - Críticas à Ciência.}

A crítica mordaz que Sanches faz ao ambiente cultural de seu tempo, de certo modo, é também uma crítica à educação de seu tempo. Mais precisamente, com relação à maneira que se dava a educação, Sanches critica o princípio da adesão compulsória e acrítica aos conhecimentos provindos de autoridades, além de reprovar a convicção de que conhecer significa saber de memória passagens de textos destas autoridades, em especial, de Aristóteles. O ímpeto libertador de Sanches entende que o saber se faz incentivando a indagação livre a revisar todo o saber adquirido acriticamente e indo buscar conhecimento diretamente nas coisas, não somente no abrigo confortável, mas duvidoso, da tradição. Tal é o quadro que se percebe após a instauração da dúvida cética como método de se libertar das ideias recebidas e aceitas inocentemente por todos aprendizes enquanto iniciam sua caminhada em direção ao saber.

No que tange ao conteúdo ensinado, Sanches ataca quatro definições de ciência: duas aristotélicas ("hábito adquirido por demonstração" e "conhecimento através das causas”), uma platônica (reminiscência) e uma do engenho do próprio Sanches ("conhecimento perfeito da coisa"). As críticas a Aristóteles são facilmente justificáveis pelo fato de o panorama cultural do renascimento ser dominado por modernos perpetuadores do pensamento aristotélico. Isto marcou, por exemplo, toda a formação do próprio Sanches, desde a escola, como já vimos. A criação de uma definição própria de ciência também parece justificável como estratégia pelos propósitos sanchesianos de fazer uma crítica a todas possibilidades de adquirirmos conhecimento perfeito. $O$ que não é de fácil justificação é o motivo da crítica à noção platônica de reminiscência, dado que a influência platônica à época de Sanches parecia ínfima, pois estava quase absolutamente esquecido nos currículos universitários, e parecia se circunscrever à divulgação em pequenos círculos intelectuais.

Sanches critica Aristóteles pela sua lógica, mas reconhece que ele foi um dos mais brilhantes exemplares do engenho humano e um atento observador da natureza. A Platão, também não deixa de exaltar como sapientíssimo filósofo. 
Ainda assim não deixa de se referir à teoria da república, à da reminiscência e à das Ideias como delírios, sonhos, ficções inúteis. Mesmo que seja uma hipótese frágil, podemos supor que o motivo deste ataque a Platão seja o hábito dos escolásticos de memorizarem e citarem frequentemente passagens do mestre estagirita, como dissemos acima. É evidente que saber algo de memória e aceitar, tal qual Platão, que saber é recordar algo esquecido pela alma através ironia e da maiêutica socráticas são coisas totalmente distintas. É pouco provável que este mal entendido tão simplório tenha confundido Sanches e por isso seja o motivo para crítica sanchesiana à teoria da reminiscência de Platão. Contudo é uma hipótese que se nos apresenta, pois a crítica a Platão surge no momento em que a noção de hábito associada ao acúmulo de conhecimentos é atacada. Aristóteles já refutou este erro de Platão, no primeiro livro dos Analíticos Posteriores, na Metafísica e no livro Sobre a Alma, como indica o próprio Sanches numa nota marginal ao texto. Esta teoria platônica, contudo, se prende ao assunto em questão. Por isso Sanches determina, então, que se diga algo próprio a este respeito.

\section{1 - Crítica a Platão}

Como dizíamos, ao refutar o conceito aristotélico de hábito, Sanches é levado a esclarecer em que sentido a memória pode indicar algum saber. Qual seja: somente na medida em que estes conteúdos da memória indicam coisas aprendidas através da contemplação exercida pelo espírito sobre imagens acumuladas na memória. Este sentido difere do sentido errôneo percebido nos escolásticos e combatido por Sanches, segundo o qual a mera quantidade de coisas ou imagens reservadas na memória indicariam sabedoria. É neste momento que surge a referência direta a Platão, o qual sustentava a opinião de que saber "não era mais do que recordar, pois antes de nós a nossa alma sabia tudo, em nós esquece tudo enquanto está encerrada no corpo, e pouco depois, como que 
desperta pela morte, lembra-se." 89 No diálogo platônico Ménon, o personagem homônimo apresenta para Sócrates um argumento que afirma não podermos buscar nem o que se conhece nem o que não se conhece, pois se já se conhece não precisa busca-lo e se não se conhece, não saberá o que buscar ${ }^{90}$. De fato, não se busca o que já se conhece sob pena de tornar exaustivo e por não se esperar inovações; e não buscamos aquilo que não conhecemos pois mesmo se o encontrássemos, não conseguiríamos reconhece-lo. A teoria da reminiscência é a resposta platônica a tal provocação erística de Ménon.

Sócrates explica que ouviu de sábios sacerdotes homens e mulheres, a quem lhes importou exercer bem sua função, que a alma é imortal, inserida num processo constante de nascimento e morte sem jamais ser aniquilada. De modo que tendo visto várias vezes tanto as coisas do reino dos vivos quanto as coisas do reino dos mortos, ela possui saberes relativos à virtude e a todas as outras coisas. Sendo a natureza idêntica a si mesma e tendo a alma aprendido todas as coisas, nada a impede de ao rememorar uma coisa, conseguir posteriormente relembrar de todas as outras. "Pois, pelo visto, o procurar e o aprender são, no seu total, uma rememoração." ${ }^{91}$ Desta maneira, a teoria da reminiscência estabelece que a alma já possui em si mesma uma série de noções, concebendo o aprendizado como o processo de relembrar aquilo que a alma já sabe desde antes da vida atual e que esqueceu devido ao trauma causado pelo nascimento.

Sanches se opõe, não aceitando a ciência como um monte de coisas guardadas em nossa memória também neste sentido platônico. Para ele, Platão é mais um criador de ilusões, e está novamente propondo uma quimera inconsistente, propondo algo que "não passa de uma agradável ficção não confirmada pela experiência e nem pela razão, assim como muitas outras coisas que ele sonhou acerca da alma (...)"92. Este apelo à razão e à experiência, veremos adiante, deve receber algumas ressalvas, pois posteriormente Sanches também apontará defeitos incontornáveis nestas duas ferramentas quando utilizadas para se obter conhecimento perfeito.

Devemos ressaltar que Sanches, como ele o indica em uma nota marginal ao texto, só se refere ao Ménon como base de sua crítica à teoria da ciência como

\footnotetext{
${ }^{89}$ SANCHES, F., Que Nada se Sabe, p. 80.

${ }^{90}$ PLATÃO, Ménon, p. 49. 80d.

${ }^{91}$ Ibid., p.53. 81d.

92 SANCHES, F., Que Nada se Sabe, p.80.
} 
reminiscência, quando sabemos que tal tema também foi desenvolvido no diálogo Fédon. Manuel Ignacio Bermúdez Vázquez ${ }^{33}$, no entanto, sustenta convincentemente que há elementos que indicam que Sanches também usou o Fédon em sua crítica á reminiscência. Primeiramente, a passagem do Quod Nihil Scitur citada acima, na nota 1 , onde Sanches diz que nossa alma sabia tudo antes de existirmos e esqueceu tudo ao passar a residir em nosso corpo, expressa o processo de esquecimento de tal forma que nos lembra das palavras do Fédon, tanto pelo argumento quanto pelas palavras escolhidas. No que tange às palavras escolhidas, somente no Fédon há esta menção a uma imersão da alma no corpo, conceito de todo ignorado no Ménon. Com relação à argumentação, o esquecimento da alma é um dos pontos cardeais do desenvolvimento da teoria da reminiscência no Fédon.

Os processos do esquecimento e da rememoração são descritos por Platão no Fédon. Nestes trechos Platão, via Sócrates, diz que

(...) poder-se-ia supor que perdemos, ao nascer, essa aquisição anterior ao nosso nascimento, mas que mais tarde, fazendo uso dos sentidos a propósito das coisas em questão, reaveríamos o conhecimento que num tempo passado tínhamos adquirido sobre elas. Logo, o que chamamos de 'instruir-se' não consistiria em reaver um conhecimento que nos pertencia? E não teríamos razão de dar a isso o nome de 'recordar-se'? (...) É possível, com efeito - e assim pelo menos nos pareceu - que ao percebermos uma coisa pela vista, pelo ouvido ou por qualquer outro sentido, essa coisa nos permita pensarmos num outro ser que tínhamos esquecido, e do qual se aproximava a primeira, quer lhe seja semelhante ou não. ${ }^{94}$

Como fica posto acima, Platão supõe podermos aceitar que esquecemos nossos conhecimentos adquiridos pela alma em outras vidas no momento do nascimento do corpo e que, posteriormente, através de estímulos sensíveis de coisas semelhantes ou diferentes destes saberes, podemos recordá-los. É nesta noção de estímulo sensível como base da recordação que encontra-se o segundo indício de que Sanches também tinha o Fédon no horizonte de sua crítica a Platão. Entre os novos elementos inseridos para melhor desenvolvimento da teoria da reminiscência, encontra-se a estratégia de dizer que a memória recapitula o que já conhecia através de associações, quando a percepção de uma coisa inesperadamente faz vir à tona a menção a outra coisa a ela associada. Quando Sanches diz que “(...) em ocasião em que se apresenta coisa semelhante em si, ou

${ }^{93}$ VÁZQUEZ, M. I. B., La recuperación del escepticismo en el Renacimiento como propedéutica de la filosofía de Francisco Sánchez. Madrid: Fundación Universitaria Española, 2006.

${ }^{94}$ PLATÃO, Fédon, p. $85.75 \mathrm{e}-76^{\mathrm{a}}$. 
pelas suas consequências, elas (as coisas conhecidas em outras vidas da alma) saem para a imaginação, e como já antes aí tinham estado, recordamo-nos"95, parece estar se referindo a um dado que faz parte da dinâmica argumentativa do Fédon. A explicação que Sanches dava sobre de que forma pode-se com propriedade aceitar que muitas coisas na memória podem ser consideradas como indício de saber, à qual aludimos no início do capítulo, é de certa forma parte da explicação platônica contida no trecho supracitado do Fédon. Apesar de possíveis diferenças qualitativas, note-se a semelhança entre ambas as argumentações ao sustentarem que as coisas que conhecemos demandam um processo mental para tal tarefa e, portanto, relembrar, neste caso, é índice de uma tentativa bem sucedida de análise prévia de algo. Mais especificamente, ao dizer que "olhandoas (as coisas guardadas na memória) com o mínimo esforço já as compreende, porque já as compreendera" 96 , Sanches parece demonstrar familiaridade com o que Sócrates diz no final da passagem supracitada do Fédon acerca da aproximação entre uma experiência sensível, semelhante ou diferente do que memorizamos, e o papel incitador desta para a rememoração, que nada mais é do que reavivar na memória o que já sabíamos e havíamos esquecido.

A teoria platônica demonstra um certo imanentismo, na medida em que para serem conhecidos, os objetos já devem encontrar-se na mente. Sanches ataca esta postura, que desintegra o objeto do conhecimento ao tentar inseri-lo no sujeito, afirmando este elemento como o único existente. Os defensores de tal teoria dizem que tudo o que conhecemos já está em nós. Ironicamente, Sanches diz que um asno também deve estar dentro deles ${ }^{97}$. Isto é dito, mais uma vez, no limite entre a crítica sanchesiana ao hábito, conceito constituinte de uma das definições aristotélicas de ciência, e o início da crítica à teoria platônica da reminiscência. Como se percebe, levanta-se a questão sobre a relação entre corpo e alma, da qual trataremos quando cuidarmos da versão sanchesiana de ciência. A teoria segundo a qual só existem as coisas que estão na mente humana pode ser considerada como parte integrante de um outro erro: a crença na infalibilidade absoluta das faculdades humanas. Esta confiança demasiadamente incauta é um

\footnotetext{
${ }^{95}$ SANCHES, F., Que Nada se Sabe, p. 81.

${ }^{96}$ Ibid., p. 80.

${ }^{97}$ Ibid., p. 79.
} 
dos principais alvos do Quod Nihil Scitur e isto também ficará mais bem explicado quando tratarmos da versão de ciência vinda de Sanches.

A crítica de Sanches é montada sobre um ponto de vista filosófico e outro médico, possibilitado pela estreita relação que o curriculum renascentista forneceu para a sua formação. De um ponto de vista médico, semelhantemente ao fato de que um conjunto de imagens presentes na vista é condição necessária, mas não suficiente para a formação de uma percepção visual, o acúmulo de coisas na mente não é saber, diz Sanches, mas sim, memória. Pois identicamente, "aquele que conta o que viu, não vê." 98

Toda a crítica sanchesiana à anamnese está marcada pela distinção entre memória e ciência. Enquanto Platão acredita que "pelo visto, o procurar e o aprender são, no seu total, uma rememoração"99, Sanches defende que "saber e recordar são coisas diversas ${ }^{100 "}$ como mostram os próprios significados destas palavras. Veremos no seguimento de nosso trabalho que Sanches exerce uma crítica mordaz às definições, considerando-as como sendo convenções arbitrárias que não condizem necessariamente com a essência daquilo que tentam mostrar. Ainda assim Platão pode ser acusado de ter cometido o erro básico de desrespeitar a convenção dos significados atribuídos a estas palavras ao utiliza-las de modo permutável. Pois, por exemplo, homem e cavalo, que são dois animais, são diferenciados com a atribuição das palavras bípede àquele e quadrúpede a este, e caso a mesma lógica de associar indistintamente conteúdos da memória a conhecimentos científicos lhes fosse aplicada, não poderíamos distinguir o homem do cavalo como o fizemos.

Separadamente desta questão linguística, Sanches critica a teoria de Platão dizendo que aquilo que aconteceu antes de minha existência, não posso conhecelo. O próprio Platão precisaria ter visto sua alma conhecendo as coisas antes da entrada em seu corpo para que pudesse crer em sua teoria, o que o levaria a ser um tipo de espectro e não um homem. De modo que se torna difícil crer nos mitos que outro homem criou.

Continuando sua argumentação, Sanches dá mais um sinal de que, mesmo sem a menção explícita, tem o Fédon no horizonte de sua atenção, pois considera

\footnotetext{
98 SANCHES, F., Que Nada se Sabe, p. 80.

${ }^{99}$ PLATÃO, Ménon, p. 49. 81d.

${ }^{100}$ SANCHES, F., Op. Cit., p.82.
} 
a mesma hipótese que Sócrates aponta em outro trecho da passagem 76a, a qual citamos acima. Neste trecho Sócrates indica dois possíveis caminhos que a teoria da reminiscência pode seguir e pede ao seu interlocutor que decida qual deles é de fato a melhor hipótese. Das duas uma: ou já nascemos com o conhecimento e este nos é acessível diretamente durante toda nossa vida; ou, após o nascimento, relembramos as ideias que já estariam em nós, porém esquecidas. Em ambos os casos, como se nota, já nascemos com as ideias. A diferença é que na primeira hipótese as ideias inatas não precisariam ser relembradas, o que, no segundo caso, seria necessário.

Pois bem, assim segue Sanches: "Dize: a alma, antes de entrar no corpo, sabia ou não sabia? Dizes que sabia; então, ou essa ciência da alma era sã recordação, ou não". ${ }^{101}$ Como se percebe, é a mesma situação disjuntiva proposta por Sócrates logo acima. Sabemos que a opção aceita por este será a de que temos saberes na alma desde antes do nascimento e que precisamos lembrar destes, o que é entendido por ele como aprendizagem.

Neste momento Sanches argumenta que tal teoria cria um regresso ao infinito. No Fédon, vimos, nascemos com saberes. Importa determinar se após nascermos já estão disponíveis ou se precisamos nos esforçar para rememora-los. No caso de precisarmos relembrar estes saberes, Sanches aponta a necessidade de uma alma anterior que justificaria a existência destes saberes na alma atual. E o saber daquela alma anterior à atual, não seria também uma recordação? Isto, por sua vez, gera a necessidade de uma outra alma como justificativa. "Desta maneira levar-te-ei ao infinito" ${ }^{102}$, diz Sanches. Devemos dizer que tal maneira de tratar este caso não nos parece a mais coerente. Por nossa parte não conseguimos perceber a razão deste regresso ao infinito sugerido por Sanches, dado que a alma, na abordagem platônica, é imortal e viveu outras vidas. De qualquer forma, esta hipótese, assim nos parece, pode ter sido levantada por Sanches pura e simplesmente como artifício dialético, para considerar as possibilidades argumentativas implicadas no problema tratado. Esta nossa hipótese parece aceitável, pois em seguida Sanches considera a outra hipótese possível, a de que se não é por outra alma que se recorda, então a alma recorda dos saberes esquecidos através de si mesma. Ao que se segue o questionamento sobre o

${ }^{101}$ SANCHES, F., Que Nada se Sabe, p.80.

102 Ibid., Loc. Cit. 
porquê deste esquecimento. Platão diria que por conta de estar adormecida enquanto habita sua morada corpórea. Contudo, Sanches põe nova objeção, agora, ao nosso ver, mais apropriadamente caracterizável como um regresso ad infinitum: se a alma tinha esquecido do que sabia antes de se lembrar, estes saberes anteriormente possuídos seriam também rememoração? Agora sim se instaura legitimamente uma cadeia regressiva interminável na busca da origem do saber da alma. ${ }^{103}$

Sanches se refere explicitamente a este processo interminável de busca regressiva de fundamentos para a crença em algo, seguindo pela trilha de um dos tropos céticos, aquele expresso por Sexto com as seguintes palavras:

No modo derivado do regresso ao infinito, dizemos que o que é apresentado como fonte de convicção para o problema proposto carece de uma outra fonte de convicção, que por sua vez também carece de uma fonte semelhante, que por sua vez precisa de outra fonte, e assim ad infinitum, de modo que não temos ponto de onde começar a estabelecer qualquer coisa, e a suspensão do juízo surge. ${ }^{104}$

Sexto Empírico atribui este e mais outros quatro modos a uma contribuição dos "céticos mais recentes"105. Diógenes Laêrtios especifica "Agripa e seus adeptos" 106 como os responsáveis por adicionar aos dez modos de Enesidemo outros cinco modos de condução à suspensão dos juízos. Há de se notar que estes cinco modos possuem uma característica mais formal do que os dez modos de Enesidemo, o que o possibilita ataques mais sutis às propostas dogmáticas.

Segue-se após a argumentação de Sanches que se a alma esquece tudo o que sabia antes de unir-se ao corpo, então não há recordação de nada, é óbvio, pois tudo foi esquecido. Há sim, novas impressões que podem gerar conhecimento. A anamnese se baseia em uma espécie de processo de reconhecimento-identificação realizado após experiências. O que significa que o objeto percebido atualmente é confrontado com a imagem de um objeto

103 SANCHES, F., Que Nada se Sabe, pp. 80 - 81. "E se tinha esquecido o seu saber, antes de acontecer isso, seria também recordação? Vai-se dar novamente ao infinito. Se o saber da alma não era recordação, perdeu ela por ventura o seu saber entrando no corpo? Se não perdeu, então sabe como antes disso; mas antes, segundo tu, o seu saber não era recordar." Nas duas primeiras frases temos o texto de Sanches que expressa seus questionamentos que instauraram o legítimo regresso ao infinito que apontamos. No restante da citação percebemos a tentativa de Sanches de esgotar dialeticamente os possíveis ataques à teoria platônica.

${ }^{104}$ EMPIRICUS, S., Outlines of Scepticism, p. 41. HP, I, 166. Tradução nossa.

105 Ibid., p. 40. HP, I, 164.

${ }^{106}$ LAÊRTIOS, D., Vidas e Doutrinas dos Filósofos Ilustres, p.274. Livro IX, 88. 
conhecido anteriormente ao nascimento, sendo este o critério para que haja a lembrança. Assim, se a mente está completamente vazia dos saberes anteriores ao nascer, não há objetos conhecidos nela para que possamos fazer o confronto com as novas percepções e lembrarmo-nos de algo que é evocado a partir de tais novas percepções. Por isso o reconhecimento é impossível. Não há recordação. O que há é a união entre novas impressões. Também se questiona: se a alma não esquece aquilo que sabia antes de encarnar, por que então chamamos os saberes que possui de ciência antes da encarnação e de reminiscência depois?

Mais uma vez o argumento médico contra a reminiscência. Sanches diz que quando alguém padece de perda de memória, ela não relembra casualmente as coisas, mas sim, as aprende novamente, como um menino. Este enfermo desmemoriado dirá, por exemplo, que não lembra das coisas, que nós sabemos que ele já tinha ciência, mas sim que as aprendeu. É algo que até o vulgo diz, ironiza Sanches. Este compreende que a reminiscência é uma expressão da convicção platônica de que é a alma quem conhece, restando à experiência sensível simplesmente instigar a subida à tona de tudo aquilo que está guardado nas profundezas do espirito. Isto levaria à afirmação de que o homem não conhece, e sim a alma. Para Sanches isso equivale a transformar o sonho de um homem em uma teoria gnosiológica. Novamente num tom irônico, Sanches nos questiona retoricamente: não seria isso uma inépcia?

Há ainda algo digno de menção na crítica sucinta de Sanches a Platão, que é feita em não mais do que três páginas do Quod Nihil Scitur. Como mais um argumento contra a identificação entre saber e rememorar, Sanches diz que propositalmente bateu em um cão, o qual passou a sempre ladrar quando o avistava, certamente lembrando das pancadas. Atribuindo a memória ao cão e contrariando Aristóteles sobre esta atribuição, novamente com ironia Sanches induz a questão: sabem também os cães? Em nossa época tal questão seria resolvida de outra maneira, dado que já possuímos pesquisas que estendem a capacidade biológica para a consciência a todos os mamíferos, incluindo os cães, dentre alguns outros animais não humanos ${ }^{107}$. Ter consciência não é exatamente o mesmo que ter ciência, no entanto é uma condição necessária para que haja algum

107 LOW, P., Declaração de Cambridge sobre a Consciência em Animais Humanos e não Humanos. 
tipo de conhecimento. Outro é o motivo, porém, que nos leva a tratar deste movimento feito por Sanches. Se analisarmos os tropos de Enesidemo, percebemos que Sexto Empírico faz um certo esforço para nivelar os humanos e os outros animais não humanos no que concerne aos problemas para o conhecimento. Exemplos disto são o primeiro e o terceiro Tropos céticos de Enesidemo, apresentados no livro I, parágrafo 36 das Hipotiposes Pirrônicas (respectivamente, o Modo acerca das variações entre os animais e o Modo que depende das constituições diferentes dos órgãos dos sentidos). Igualmente, no parágrafo 69, do mesmo livro I desta obra de Sexto Empírico, vemos um exemplo que atribui a um cão a capacidade de tomar conscientemente uma decisão. A postura de Sanches, antropocêntrica e comum à sua época, o afasta de Sexto Empírico neste ponto. No entanto, podemos argumentar que Sanches pura e simplesmente se apropria da argumentação necessária paras seus fins, não se obrigando a defender nenhum conjunto de pressupostos clássicos, haja vista a sua postura contra a autoridade. Além do fato de uma comparação entre os animais não ser exatamente um problema analisado por Sanches em sua empreitada sobre o conhecimento, mesmo que isso tenha feito parte do quadro cético pintado por Sexto Empírico.

\section{2 - Crítica a Aristóteles}

Como já dissemos anteriormente, os currículos escolares e universitários indicavam que o panorama cultural da época de Sanches estava dominado pelo ensino do aristotelismo. Talvez este seja o motivo principal para boa parte do Quod Nihil Scitur ocupar-se de denunciar as falhas do milenar sistema aristotélico, que parecia se manter incólume através dos séculos. Sanches avalia que o aristotelismo não contribui para o autêntico progresso do conhecimento, pois se constitui de uma infinidade de sutilezas e abstrações que foram propagadas pelos seguidores escolásticos de Aristóteles. A crítica de Sanches dá a impressão de ser completa, abarcando os aspectos fundamentais do aristotelismo, 
considerado o suprassumo do saber na época, tendo resultado na avaliação deste sistema como um formalismo desprovido de conteúdo.

Sanches inicia o Quod Nihil Scitur com uma série de ataques às definições, a base do edifício aristotélico do conhecimento, buscando evidenciar a arbitrariedade presente tanto na constituição desta ferramenta cognitiva quanto na sua utilização. Desta forma poderia mostrar a instabilidade deste instrumento e a sua incapacidade para servir de base para construções estáveis e duradouras. Nada mais apropriado e prático do que ir à raiz do problema, a linguagem, e com um único golpe acertar dois alvos, Aristóteles e seus seguidores. Deste modo, o precioso tempo que tem para conhecer algo não seria desperdiçado na vã tarefa de combater diversos oponentes.

Após incitar o seu interlocutor dogmático imaginário à dúvida, Sanches inicia sua tarefa cética de apresentar nosso estado de ignorância. $\mathrm{O}$ ponto de partida é um ataque à mais simples e fundamental parte de qualquer teoria: as definições. Aristóteles dedica boa parte dos Analíticos Posteriores à tarefa de esclarecer como se pode definir e demonstrar algo. Ele sustenta que "a definição está relacionada com a natureza essencial e é universal e afirmativa em todos os casos."108 "Além do mais, as premissas básicas das demonstrações são as definições, e já se mostrou que estas são indemonstráveis."109 Conforme Aristóteles "a divisão é o único método possível para evitar a omissão de qualquer elemento da natureza essencial." ${ }^{110}$ Este processo de divisão envolvido na forja de uma definição busca distinguir, primeiramente, o gênero próximo e em seguida, a diferença de espécie ${ }^{111}$, relativos ao objeto definido.

Sanches, por sua vez, não percebe nas definições nada além de um conjunto de palavras sem real conexão necessária com as coisas, pois como ele escreve já no final do primeiro parágrafo do Quod Nihil Scitur e em uma nota

\footnotetext{
108 ARISTOTLE, Analytica Posteriora. Tradução nossa a partir de II, 90b 3 - 5. Em II, 94a 11 14: "Concluímos então que a definição é (a) uma exposição indemonstrável da natureza essencial, ou (b) um silogismo da natureza essencial diferente da demonstração gramatical, ou (c) a conclusão de uma demonstração que apresena a natureza essencial". Tradução nossa.

109 Ibid., II, 90b 23 - 25. Tradução nossa. Logo após o trecho citado o próprio Aristóteles menciona o regesso ao infinito, criticado por Sanches, que surge da tentativa de demonstrar as definições. As passagens às quais Aristóteles se refere acerca da explicação anterior sobre a indemonstrabilidade das definições estão nesta mesma obra em II, 72 b 18 - 25 e II, 84a 30 - 84b 2.

${ }^{110}$ Ibid., II, 96b 35 - 37. Tradução nossa.

${ }^{111}$ Ibid., II, 97 a 35 - 97 b 5.
} 
marginal, "todas as definições são verbais, bem como quase todas as questões."112 Isto se dá, ele explica no parágrafo seguinte, porque "a essência das coisas não podemos conhecê-la". Um dos motivos desta impossibilidade é que, explica Sanches, os indivíduos são diversos entre si, e algumas vezes, variam suas qualidades. Alguns são bons, outros maus; alguns violentos, outros calmos; o próprio Sanches, incansável pensador, cita Horácio para dizer que algumas vezes atira com ira os livros para longe de si e foge das bibliotecas. ${ }^{113}$ Deste modo, a ciência perfeita, caso fosse possível, deveria ser "de cada coisa por si." ${ }^{114}$ Isto é, ser dos indivíduos, que são acessíveis através dos sentidos, e não através de abstrações que tentam abarcar em um conceito universal toda a infinita diversidade existente, excluindo aquilo que considera como acidental à natureza do seres, sem saber se o faz devidamente. $O$ aristotélico, todavia, dirá que não existe ciência dos indivíduos, justamente pela sua vastidão. Sanches responderia que

(...) as espécies não são nada, ou são apenas uma fantasia: só os indivíduos é que existem, só estes é que afetam os sentidos, só deles é que pode haver ciência, e deles deve esta ser tomada; se assim não é, mostra-me na natureza esses teus célebres universais. Dirás que estão nos próprios particulares. Ora eu não vejo neles nada de universal: são particulares. ${ }^{115}$

Dir-me-ás que uma andorinha não faz a primavera, nem um particular destrói o universal.

Eu, pelo contrário, afirmo que o universal é absolutamente falso, a não ser que abranja e afirme, exatamente como elas são, todas as coisas que neles se contêm. ${ }^{116}$

Ainda acerca das definiçõos, Sanches continua a criticar as distorções dos significados das palavras, realizadas pelos dialéticos seguidores de Aristóteles, com o intuito de ornar seu discurso e serem reverenciados pelos que não conhecem tais coisas. Critica igualmente a afirmação que fazem de que somente as línguas grega e latina possibilitam o ensino da filosofia, devido à existência de alguns termos somente nestas línguas. E por final, contra a tese segundo a qual as palavras existem por força da própria natureza dos objetos, Sanches contrapõe a pergunta pelas diferenças entre as línguas, que nos mostram diferentes nomes para os mesmos objetos. Deste modo as divisões aristotélicas em gênero e espécie, a

112 SANCHES, F., Que Nada se Sabe, p. 67.

113 Ibid., p. 93.

114 Ibid., p. 92.

115 Ibid., p. 93.

116 Ibid., p. 94. 
sua pretensa universalidade e a identidade entre as palavras e a essência das coisas caem por terra.

Não têm, portanto, as palavras nenhuma faculdade de indicar a natureza das coisas a não ser aquela que lhes vem do arbítrio de quem as cria. (...) Efetivamente, quem é que conhece a essência das coisas para lhes impor nomes em virtude delas? O que há de comum entre as coisas e as palavras? ${ }^{117}$

Após estas palavras, Sanches também registra nesta mesma passagem, em duas notas marginais ao texto: "As palavras não explicam a essência das coisas" e "Não há relação íntima entre as palavras e as coisas". No entanto, existem os nomes, daí seguem-se dúvidas, confusão e sofismas intermináveis, culminando na incapacidade de determinar a real razão de tais nomes. Apesar de parcial e, de certa forma, redutivista, tal visão de Sanches indica um ponto fundamental do pensamento de Aristóteles.

Mas ainda não termina aqui a crítica sanchesiana às definições. $\mathrm{O}$ fato, ao qual aludimos acima, de as definições serem integrantes da demonstração que não são passíveis de serem demonstradas, é notado por Sanches, que aponta o regresso ao infinito causado pela tentativa de definir qualquer coisa. Um exemplo clássico vindo de Aristóteles, a definição de homem como animal racional mortal, é analisado por Sanches. Ele duvida da possibilidade de identificação entre estes nomes e o objeto que tentam definir, apontando a impropriedade do processo de divisão em gênero e diferenças específicas, até chegar ao Ente, tal qual se propõe em Aristóteles. Tais palavras, diz Sanches, também precisam ser definidas, além de permanecerem incógnitas, pois "a verdade é que não sabes o que é o Ente, e eu ainda menos."118 Aqui Sanches recorre ao Tropo cético do regresso ao infinito, que já havia sido apontado pelo próprio Aristóteles como pertencente a esta situação, pois as ferramentas utilizadas para a definição também carecem de definição. Mas no seguimento da discussão, o interlocutor dogmático afirma "que deve forçosamente haver um ponto em que terminem as nossas investigações."119 Desta vez um novo Tropo cético de Agripa é suscitado pela reação do dogmático. Ao tentar livrar-se da regressão ao infinito, o dogmático postula indevidamente uma hipótese para resolver seu problema. Este é o quarto Tropo de Agripa, referido no parágrafo 164 e explicado no parágrafo 173 do livro I das Hipotiposes

${ }^{117}$ SANCHES, F., Que Nada se Sabe, p. 97.

118 Ibid., p. 68.

119 Ibid., Loc. Cit. 
Pirrônicas ${ }^{120}$, por exemplo. Tal postulação não resolve o problema do dogmático, que é obrigado a mostrar sua ignorância conjuntamente com Sanches.

Sexto Empírico também se refere às definições nos parágrafos 205 a 212 do livro II das suas Hipotiposes Pirrônicas ${ }^{121}$. Neste trecho ele apresenta as definições como desnecessárias para a tentativa de apreensão dos objetos e para o ensino, aponta o regresso ao infinito causado pela tentativa de definir, considera o mesmo exemplo de definição de homem como animal racional mortal, diz que as definições não podem ser julgadas verdadeiras devido à infinidade dos indivíduos que elas tentam acolher, e conclui sustentando que as definições são dispensáveis porque não definem devidamente aquilo a que se propõem e criam situações desnecessárias de incompreensão caso as utilizemos para expressar coisas triviais, como nossas referencias a objetos individuais e aquilo que desejamos. Nos parece que encontramos aqui mais alguns pontos de contato entre a argumentação de Sexto e a de Sanches.

Em seguida Sanches escolhe duas noções de ciência que Aristóteles parece ter formulado: "a ciência é habitus per demonstrationem acquisitus"122 e "conhecer as coisas pelas suas causas"123. Há de se apontar que dentro do sistema de Aristóteles, ambas as definições não aparecem separadamente, havendo uma relação de subordinação entre elas, na medida em que a primeira é condição necessária para a segunda. Porém, é devido a esta estratégia que Sanches consegue o caminho para a crítica dos fundamentos do pensamento de Aristóteles. Este procedimento indica pelo menos duas coisas. Primeiramente, a liberdade com a qual Sanches utiliza suas fontes, não se prendendo às suas estruturas, tanto no que tange às citações, como já vimos, quanto no que diz respeito à apropriação que faz das teorias analisadas. Em segundo lugar, este processo de análise, que aponta e crítica, um por um, os conceitos constitutivos básicos de uma teoria, lembra a estratégia comumente utilizada por Sexto Empírico.

Não consta em nenhuma obra de Aristóteles a expressão exata que Sanches utiliza para se referir à primeira noção de ciência que ele combate, aquela que sustenta que a ciência seja um hábito adquirido pela demonstração. É possível que Sanches a tenha abstraído a partir de um quadro geral do aristotelismo. A nota

${ }^{120}$ EMPIRICUS, S., Outlines of Scepticism, pp. 40 e 42. HP, I, 164 e 173.

${ }^{121}$ Ibid., p. 123 - 125. HP, II, 205 - 212.

${ }^{122}$ SANCHES, F., Que Nada se Sabe, p.70.

${ }^{123}$ Ibid., p. 82. 
marginal onde Sanches indica a fonte de tal definição é genérica: "definição da ciência dada por Aristóteles". Como já dissemos anteriormente, Sanches não é mesmo um pensador que se preocupa em relatar fielmente todas suas fontes, parecendo estar mais preocupado com a finalidade da sua argumentação do que com o registro de suas origens.

Uma passagem onde Aristóteles diz algo próximo a isto se localiza nos Tópicos, I, 105b 28. Neste texto diz-se que a natureza dos tipos de proposições não é facilmente apresentada por uma definição, no entanto devemos tentar reconhecer estes tipos diferentes de proposições por meio de uma "familiaridade adquirida por indução." 124 Existem motivos para que descartemos esta passagem como fonte da definição apresentada por Sanches.

Primeiramente, esta obra de Aristóteles trata de apresentar uma técnica útil para que se possa argumentar com ares convincentes independentemente de haver fiel correspondência entre a argumentação e os fatos discutidos. Os Tópicos, diz Aristóteles, têm a finalidade "de encontrar um método pelo qual estejamos aptos para raciocinar a partir de opiniões geralmente aceitas acerca de qualquer problema proposto, e também poderemos evitar dizer algo que nos obstrua quando participarmos de uma discussão." 125 Estas “opiniões geralmente aceitas" são elementos que parecem aceitáveis por todos, e diga-se, são diferentes dos autênticos princípios da ciência que devem ser verdadeiros e ter valor em si mesmos. Aristóteles marca bem a distinção entre o tipo de argumentação voltado para a ciência propriamente dita e o tipo de argumentação utilizada em disputas com adversários. Sanches deve ter percebido tal distinção fundamental.

Em segundo lugar, Sanches conhecia a distinção entre silogismo e indução. Sem subestimar o valor da dialética e o papel dos Tópicos dentro do sistema aristotélico, Sanches deveria buscar seu objetivo em um texto que apresente uma noção de ciência diferente daquela do conhecimento pelas causas, que está nos Analíticos Posteriores, na Física e na Metafísica, à qual precisava desmembrar e atacar a partir de seus fundamentos.

Pode ser, então, que a definição que Sanches apresenta como aristotélica, "habitus per demonstrationem acquisitus" origine-se na passagem VI, 3, 1139b 33

${ }^{124}$ ARISTÓTLE, Topica and De Sophisticis Elechis. Tradução nossa. A tradução inglesa que utilizamos diz: "familiarity attained through induction".

${ }^{125}$ Ibid., I, 100a $18-20$. 
- 35 da Ética a Nicômaco, onde Aristóteles afirma que "o conhecimento científico é um estado que nos torna capazes de demonstrar." 126 Outras possíveis passagens aristotélicas de onde Sanches pode ter extraído esta noção de ciência vêm das Categorias e de seus Analíticos Posteriores. Em Analíticos Posteriores I, 71 b 19 - 20, Aristóteles estabelece que "conhecemos através da demonstração. Por demonstração me refiro ao silogismo produtor de conhecimento científico"127, sendo a constituição por premissas verdadeiras uma das condições para que o silogismo produza conhecimento científico. Isto demonstra a consciência aristotélica da distinção dos usos que essa ferramenta pode ter. Contudo, tal dado não evitará a denúncia de Sanches sobre inaptidão da demonstração para a formulação de conhecimento, atividade atribuída ao silogismo. No trecho 8b 25 35 do capítulo 8 das Categorias, Aristóteles nos explica que "qualidades" são aquilo em virtude do qual as pessoas são ditas como sendo ou isto ou aquilo. Há vários usos para este termo, um deles é a partir da sua associação à "disposição" e ao "hábito". Este é mais duradouro e mais firmemente sustentado do que aquela. Apesar de não o associar diretamente com a demonstração, este trecho classifica o saber como um tipo de hábito, pois "o saber, mesmo quando adquirido num grau moderado, é, concorda-se, duradouro e de difícil destituição."128

Voltando-se agora para a ciência como "habitus per demonstrationem acquisitus", Sanches procede tal qual Sexto Empírico, atacando analiticamente as partes desta definição. Começando por "hábito", Sanches pergunta o que isso significa e diz que definir ciência como hábito é definir o obscuro pelo mais obscuro. O interlocutor aristotélico, seguindo o seu mestre, definiria "hábito" como uma qualidade constante, tal qual indicamos acima. A ciência deve buscar o que é duradouro e estável, "deve formar parte das realidades permanentes que resistem às mudanças, inclusive quando adquirida em modesta medida" ${ }^{129}$ Por sua vez Sanches responderia que quanto mais tentam explicar, mais complicam e menos esclarecem. Esta definição de hábito como uma qualidade firme nos remete às categorias aristotélicas e à tentativa de tudo ser reduzido a elas. Estas, para Sanches, nada mais são do que uma série de palavras, que parecem mais buscar criar dificuldades para esconder obscuridades e conferir um ar de elevação do que

${ }^{126}$ ARISTÓTELES, Ética a Nicômaco, p.143.

${ }^{127}$ Id., Analytica Posteriora, I, $71 b 19$ - 20. Tradução nossa.

${ }^{128}$ Id., Categoriae and De Interpretatione, Capítulo 8, 8b 25 - 35. Tradução nossa.

${ }^{129}$ Ibid., Capítulo 8, 8b 30. Tradução nossa. 
fazer ciência, e recebem semelhante crítica nominalista como as definições receberam.

Este excesso de palavras igualmente se expressa num conjunto grande de concussões, das quais os lógicos se vangloriam, como se elas determinassem a mesma quantidade de conhecimentos. Os dogmáticos aristotélicos não sabem nada da realidade, não admira que se voltem sempre para as suas ficções, diz Sanches, que em uma nota marginal ao texto ataca: "os lógicos dizem que o hábito é um agregado de muitas conclusões. Esta definição é péssima. Os lógicos nada mais sabem que muitas conclusões." ${ }^{130}$ Assim como aquilo que chamamos de visão não é pura e simplesmente um conjunto de imagens enquanto afetam nossa vista, mas sim o ato do espírito de considerar estas imagens, também a ciência não é um monte de conclusões bem fixadas na mente. Caso houvesse a possibilidade de uma ciência perfeita, seria "erro chamar hábito à ciência", pois ela deveria ser "um ato simples do espírito"131, diz Sanches em duas notas marginais. O hábito é entendido, já vimos, como uma qualidade estável e bem estabelecida. Ora, a ciência não é uma qualidade, assim como a visão também não o é. Este ato simples que caracteriza a ciência perfeita, só existe enquanto parta do espírito, semelhantemente à visão. A imagem resultante da contemplação do espírito é enviada à memória, e caso aí se fixe bem, será chamada de hábito, caso não se fixe, será classificada como disposição, tal qual nas definições do próprio Aristóteles. Neste momento, o resultado desta contemplação do espírito será propriedade da memória, não mais da ciência, diz Sanches. Como explicamos anteriormente quando tratávamos de Platão, depois de memorizados, tais conhecimentos podem ser relembrados. Neste momento, mesmo que recordemos um conteúdo que mostre que já contemplamos e entendemos algo, não fazemos ciência segundo Sanches. A ciência se dá somente no momento em que contemplamos algo, de resto, o que há é lembrança. Deste modo, a ciência não pode ser associada à noção aristotélica de hábito.

$\mathrm{O}$ ataque sanchesiano à demonstração é feito através do ataque ao silogismo. Aristóteles diz que "a demonstração é um certo tipo de silogismo, mas nem todo tipo de silogismo é uma demonstração." ${ }^{132}$ Em outra parte, o estagirita

\footnotetext{
${ }^{130}$ SANCHES, F., Que Nada se Sabe, p. 77.

${ }^{131}$ Ibid., p. 79.

${ }^{132}$ ARISTOTLE, Analytica Priora, I, 25 b 30. Tradução nossa.
} 
também diz que "em todos os casos, nós sabemos através da demonstração. Por demonstração entendo um silogismo produtor de conhecimento científico, isto é, a compreensão daquilo que é eo ipso tal conhecimento."133

Apesar de toda esta sistematicidade de definições preliminares Sanches diz que a ciência do silogismo é sutil, longa, difícil e fútil. ${ }^{134}$ E como adverte o próprio Aristóteles, não é todo silogismo que pode gerar ciência. Há silogismos nos quais "uma conclusão verdadeira pode ser tirada a partir de premissas falsas." 135 Para ter uso científico as "premissas do conhecimento demonstrado devem ser verdadeiras, primárias, imediatas, melhor conhecidas e anteriores à conclusão, que é relacionada a elas como um efeito à sua causa." ${ }^{136}$ E como já dissemos acima, para Aristóteles "conhecemos através da demonstração."137

Sanches, por sua parte, novamente aponta que é mais obscura a prova do que aquilo que se quer provar. Através da tentativa de demonstrar que o homem é uma substância Sanches exemplifica as dificuldades da demonstração silogística, que dificulta o entendimento do definido ao inseri-lo nas categorias, na forma e nas modificações linguísticas silogísticas, atrapalhando o entendimento ao invés instruí-lo, tornando-se prática degeneradora do saber. Segue-se que "finalmente tudo o que se encontra na Metafísica e nas restantes obras de Aristóteles são definições de nomes." 138 Os problemas que costumam assombrar os seguidores de Aristóteles são tais como se podemos ou não atribuir a categoria de substância ao homem, ou se este é corretamente classificável de animal racional mortal etc. Caso nos atenhamos à definição aristotélica de ciência em questão, então não há ciência. Ele diz que ela é obtida por demonstração. "Mas o que é demonstração? Um sonho de Aristóteles, semelhante à República de Platão, ou à do orador Cícero ou do poeta Horácio."139 O formalismo vazio com o qual trabalhou Aristóteles usando A, B e C como os termos do silogismo não teria se prolongado caso ele tivesse utilizado noções simples no lugar destas letras, pois assim teria visto que nada se consegue dos silogismos. Não admira, conforme Sanches,

\footnotetext{
133 ARISTOTLE., Analytica Posteriora, II, 71 b 16 - 18. Tradução nossa.

${ }^{134}$ SANCHES, F., Que Nada se Sabe, p. 72.

135 ARISTOTLE, Analytica Priora, II, 53b 8. Tradução nossa.

${ }^{136}$ Id., Analytica Posteriora, I, 71b 20 - 22. Tradução nossa.

${ }^{137}$ Ibid., I, $71 b 19$ - 20. Tradução nossa.

138 SANCHES, F., Op. Cit., p. 74.

${ }^{139}$ Ibid., p. 75.
} 
Aristóteles ter se dedicado à sofística com a finalidade de nos livrar dos erros contidos nos usos do silogismo.

Ao invés de demonstrar a natureza do definido, o silogismo só mostra os objetos que devem ser conhecidos. Sanches critica a universalidade do silogismo por ele ignorar as individualidades, na medida em que tenta por em relevo as classes gerais. Para Aristóteles os objetos universais são mais cognoscíveis do que os particulares e a demonstração universal é maior do que aquela particular, pois quem conhece o objeto universal conhece também o particular, enquanto quem conhece o particular não conhece o universal. A universalidade é atacada com a inversão do argumento deste ponto de vista de Aristóteles, pois Sanches não aceita que as particularidades devam ser abandonadas frente às universalidades, que tentam incompleta e imperfeitamente minimizar aquelas em detrimento de uma visão média geral.

Em detrimento do ensino prejudicial e torturante de ficções advindas do silogismo, Sanches propõe a observação direta da natureza. O hiato que se cria entre a palavra e a coisa é a maior razão para Sanches duvidar da propriedade do uso dos silogismos com o intento de se obter conhecimento universal, necessário e verdadeiro sobre a natureza.

À possível acusação de tentar demonstrar que não pode haver demonstração e à possível precariedade da crítica feita a Aristóteles, Sanches diria que tão pouco se propôs demonstrá-lo (usando o termo 'demonstrar' no sentido dogmático), nem poderia fazê-lo, pois lhe parece

extraordinariamente insensato o que alguns afirmam, - que a demonstração conclui e infere necessariamente de princípios eternos e invioláveis, quando talvez não os haja, ou, se os há, são absolutamente desconhecidos como tais para nós que somos imensamente corruptíveis e em brevíssimo espaço de tempo tão violáveis. ${ }^{140}$

Assim, Sanches logra não abrir o flanco para o contra ataque na acusação de ter demonstrado que não pode haver demonstração.

Finalmente Sanches apresenta outra noção de ciência vinda de Aristóteles, nos Analíticos Posteriores, mas retomada e aprofundada na Física e na Metafísica. A doutrina da causalidade de um modo ou de outro foi parte integrante de toda investigação que veio posteriormente à formulação aristotélica. Sanches

${ }^{140}$ SANCHES, F., Que Nada se Sabe, p. 77. 
admite isto ao dizer numa nota marginal que "todos depois dele" aceitam tal doutrina.

Aristóteles sustenta que "possuímos conhecimento científico de algo somente quando conhecemos a sua causa." ${ }^{141}$ Este filósofo também determina que as causas são necessariamente finitas quanto ao número, que devem existir causas primeiras na base da ciência e que estas não necessitam de outras causas. Estas são as causas formal, material, eficiente e final.

Iniciando pela causa eficiente, Sanches argumenta contra esta definição de modo não muito original. Ele usa o clássico exemplo lançado contra Aristóteles: caso quiséssemos conhecer um homem, deveríamos conhecer seu pai, que é sua causa. Também teríamos que conhecer o pai deste, avô do primeiro, que é a causa do pai do homem que desejamos conhecer. E assim por diante, caindo a argumentação aristotélica novamente num regresso ao infinito. A causa final é deposta por Sanches nos mesmos termos, pois a busca pela finalidade de algo nos levará igualmente à necessidade de regredir infinitamente buscando os objetivos dos objetivos das coisas. E a tentativa de associar o conhecimento das causas eficiente e final com o saber científico cai ainda e outra armadilha disposta nos Tropos céticos. Ao tentar finalizar o regresso infindável da cadeia das causas eficiente e final, o dogmático apresenta Deus como causa produtora e fim último de tudo, dizendo que neste não podemos penetrar, pois o infinito nos é interditado. Neste momento, ao apresentar Deus como a primeira causa, sem que esta possa ser demonstrada e, portanto, não possa ser conhecida, o dogmático cai nas malhas do quarto Modo de Agripa, o Tropo da hipótese postulada autoritariamente. Então, conforme a doutrina da causalidade, conhecer Deus, Motor Imóvel, que é eterno, imóvel e puro ato, é necessário para conhecer todas as outras coisas, na medida em que Ele é a primeira causa eficiente de tudo o que existe. Sanches é partidário da opinião de que não podemos conhecer Deus. Consequentemente, a partir das causas eficiente e final, nada se sabe. Sanches diz ao aristotélico: "se segue que não sabes nada: foges do infinito, e afinal cais no infinito, imenso, incompreensível, indizível, ininteligível." 142

Sanches parte então para a análise da causa formal. Aqui ele levanta a seguinte objeção: se quisermos conhecer a forma, é preciso que conheças as

\footnotetext{
${ }^{141}$ ARISTOTLE, Analytica Posteriora, I, 71b 30. Tradução nossa.

${ }^{142}$ SANCHES, F., Que Nada se Sabe, pp. 82 - 83.
} 
causas desta, segundo a própria definição dada por Aristóteles. A causa formal assume uma posição privilegiada no pensamento de Aristóteles, pois ela coincide com a essência. Então, possivelmente todas as críticas aplicadas à definição aplicam-se também à causa formal. Isto é, se aceitarmos a distância entre a palavra e a coisa, e a arbitrariedade da classificação dos objetos através de termos abstratos como género e diferença específica, segue-se que as definições são inválidas como instrumento para o conhecimento, e por consequência, já que a definição, ou essência de algo, se relaciona com a causa formal, então esta também não é uma noção apropriada para o conhecimento. Este é um caminho de análise apontado por nós. O caminho traçado por Sanches, nesta altura, contudo, é outro.

Sanches também aponta que para conhecer uma das causas é necessário que se conheça todas as outras três. Ora, só nos restaria a causa material, dado que as causas eficiente e final já foram destituídas de validade por conta do regresso ao infinito no qual se enredam. Sem conhecermos as duas causas anteriores, não poderemos conhecer esta outra, a formal. Se não tivermos conhecimento da causa formal, não teremos acesso igualmente à causa material, dado que esta, assim como todas as outras, se envolve neste processo de interdependência para a constituição e o conhecimento das causas entre si. Na relação de reciprocidade da definição de uma causa com as outras se estabelece um circulo vicioso, do qual não se pode sair. Esta é mais uma das armas do arsenal cético, o quinto Tropo de Agripa $^{143}$, aquele que chega à suspensão justamente pela incapacidade de decidir e conhecer advinda desta reciprocidade.

Sanches pergunta ao seu interlocutor aristotélico se ele pode, de fato, ter o conhecimento de pelo menos duas das quatro causas. Do alto de seu orgulho, evidentemente, ele responde que sim. Ao qual Sanches contra argumenta: esta ciência das causas, ou se obtém através das causas ou se obtém sem as causas. Se o último caso for verdadeiro, a doutrina da causalidade perde seu valor na medida em que aceitarmos que ela mesma não pode ser explicada pelos seus elementos. Se o primeiro caso é verdadeiro, então, novamente surge o problema do regresso ao infinito, pois seria admitir que a doutrina das causas é obtida por outras causas.

${ }^{143}$ EMPIRICUS, S., Outlines of Scepticism, p. 41. HP, I, 164, onde se apresenta o quinto Modo. $H P$, I, 174, na p. 42, onde se explica como neste Modo postula-se tanto o objeto investigado e sua definição ao se criar uma relação de interdependência entre eles. 
A definição também está sujeita a este regresso ao infinito, pois uma definição sempre carece de outra que a esclareça, e a busca por definições antecedentes não cessa. O próprio Aristóteles estabelece que não há ciência dos princípios, pois só há ciência onde pode haver demonstração, nos restando somente a compreensão de tais princípios. Estes são interpretados como proposições primárias de um silogismo, enquanto as causas são tidas como proposições médias entre os princípios e a conclusão. "Acaso não é isso uma ficção sutil?"”144

Não sabemos ao certo se Sanches acessou diretamente a obra Sexto Empírico, que já se encontrava disposta em publicações com traduções latinas na sua época. Fornecemos até aqui algumas razões que nos levam a crer na possibilidade deste contato. Motivos de caráter tanto histórico, no capítulo sobre a vida de Sanches, quanto argumentativos, aqui neste capítulo e no anterior quando tratamos do tipo de dúvida cética contida no pensamento de Sanches. É curioso o fato de Sanches não utilizar, pelo menos não direta e sistematicamente, o auxílio das fontes céticas antigas na sua crítica feita à doutrina da causalidade, sabendo que este foi um dos eixos centrais da crítica cética aos dogmatismos que combateu. Em Adversus Mathematicos, uma longa e severa crítica é exercida contra o critério, a demonstração, assuntos antes tratados por Sanches, e contra a causalidade, que agora o ocupa. Os oito Modos de Enesidemo ${ }^{145}$ contra a causalidade, apresentados nas Hipotiposes Pirrônicas, são um bom exemplo de uma ferramenta que poderia ser utilizada para refutar cada razão tradicional para as causas. Estes Tropos indicam que as explicações causais tratam daquilo que não é evidente ( $1^{\circ}$ Tropo), só explicam por um caminho apesar de haver diversos ( $2^{\circ}$ Tropo), costumam transferir as explicações daquilo que é aparente para aquilo que não é aparente ( $4^{\circ}$ Tropo), consideram somente sua hipótese explicativa e não as comumente aceitas ( $5^{\circ}$ Tropo), rejeitam as hipóteses contrárias mesmo que igualmente plausíveis ( $6^{\circ}$ Tropo) e apresentam hipóteses que conflitam com o que é aparente e também com suas próprias hipóteses ( $7^{\circ}$ Tropo). Estes Modos certamente poderiam ser aplicados a alguns dos momentos argumentativos de Sanches que vimos até agora. Nenhuma menção direta a Sexto Empírico foi feita, nem mesmo nos casos de regresso ao infinito e dialelo que apontamos. Provavelmente Sanches não seguiu, como um fiel, o uso dos Tropos para não cair

\footnotetext{
${ }^{144}$ SANCHES, F., Que Nada se Sabe, 84.

${ }^{145}$ EMPIRICUS, S., Outlines of Scepticism, pp. 44 - 46. HP, I, 180 - 186.
} 
no mesmo erro que criticou nos homens de ciência de sua época: aceitação acrítica de autoridades.

\section{3. O Conhecimento Perfeito do assunto}

Após a instauração inicial da dúvida e da análise de três das principais respostas dadas por grandes pensadores antigos ao problema sobre a natureza do conhecimento, esta questão continua sem resposta. Chega a vez do próprio Sanches tentar contribuir para o esclarecimento de tal questão. Mas o que sustentará este filósofo português? O mesmo que assim se expressa: "Que direi eu, com efeito, que não seja suspeito de falsidade? Realmente para mim todas as coisas humanas são suspeitas, incluindo mesmo as que eu agora escrevo."146 É condizente à sua argumentação o tom do anuncio da sua tentativa: "Até aqui mostrei a ignorância dos outros acerca da definição de ciência, e portanto acerca do conhecimento; agora vou dar a minha definição, para que não pareça que sou eu o único a saber alguma coisa. Por aqui poderás tu ver quão ignorantes somos." 147 Tendo descreditado a rememoração no sentido platônico, exercido uma crítica ao costume escolástico do simples acúmulo de saberes tradicionalmente reverenciados, e tendo destituído de valor tanto a demonstração quanto busca da causalidade provindas de Aristóteles, Sanches sente-se na obrigação de mostrar a partir de recursos próprios o que entende por ciência e por quais motivos sua definição também não pode ser realizada.

"A ciência é o conhecimento perfeito do assunto"148 (scientia est rei perfecta cognitio): apresenta Sanches a definição de ciência que lhe parece verdadeira. Esta definição ocupa boa parte do Quod Nihil Scitur, e parece fazer toda a crítica anterior servir-lhe de introdução na medida em que, pouco a pouco, enquanto estabelece a dúvida e critica algumas noções de ciência, Sanches apresenta gradual e conjuntamente algumas características da sua própria

\footnotetext{
${ }^{146}$ SANCHES, F., Que Nada se Sabe, p. 75

${ }^{147}$ Ibid., p. 85.

148 Ibid., Loc. Cit.
} 
concepção. Tais características são adiantadas em várias notas marginais ${ }^{149}$ ao texto durante os ataques céticos de Sanches: "A verdadeira ciência é livre e filha de espírito livre", ao invés da subserviência intelectual às autoridades do saber; “A ciência é uma visão interna”, "um ato simples do espírito", isto é o movimento ponderador do espírito em relação às impressões e não "é um montão de muitas coisas na mente", por isso "douto não é quem tem a memória bem recheada, mas o que entende"; "A ciência não difere da compreensão ou entendimento" "é una, e não dupla; há todavia duas maneiras de saber", uma maneira é a simples onde conhecemos algo simples como a matéria, a forma, e o espírito, e a outra maneira é a composta, e aquela sempre é anterior a esta, sem que esta necessariamente siga aquela; a ciência deve ser feita de cada coisa individualmente pois assim não se perde o contato com a completude de cada ser; "O verdadeiro saber é conhecer primeiro a natureza das coisas e depois os acidentes" e "Para o conhecimento perfeito de uma coisa é preciso conhece-las todas", de onde também resulta que “Toda a ciência é uma ficção".

Estas referências àquilo que Sanches crê que seja a ciência verdadeira não esgotam o que ele tem a dizer acerca da sua definição. Igualmente podemos pensar que tal definição é sustentada como parte de uma estratégia dialética, pois apresenta mais um discurso discordante dos outros, ao qual o próprio Sanches também se encarrega de demolir, após haver erguido uma nova concepção de conhecimento tão dogmática quanto o é possível. Esta hipótese da noção sanchesiana de conhecimento ser um expediente dialético parece aceitável, pois como já mostramos, Sanches é um usuário do tipo de argumentação in utranque partem que caracteriza a persuasão cética, tanto no viés pirrônico quanto no acadêmico. Esta hipótese é igualmente interessante, pois apesar de mostrá-la como artifício para ratificar sua posição de que não podemos ter conhecimento perfeito da realidade, Sanches diz no parágrafo acima da primeira menção explícita a esta noção: "o que tem sido aceite por muitos parece-me falso, como já mostrei; o que eu agora vou dizer parece-me verdadeiro." ${ }^{150}$ No seguimento de nossa argumentação mostraremos que ao criticar esta noção de ciência, entendida como o conhecimento perfeito das coisas, Sanches posicionasse a favor de um conhecimento limitado aos acidentes, às características secundárias, dos objetos

${ }^{149}$ SANCHES, F., Que Nada se Sabe, pp. 77 - 79 e $84-87$.

${ }^{150}$ Ibid., p. 85. 
estudados, devido aos diversos problemas relativos aos objetos e aos sujeitos envolvidos na relação cognitiva, de modo que se aqueles não são perfeitos, este também não o será. Aqui acreditamos haver um ponto de contato de Sanches com o ceticismo acadêmico, sobretudo o de Carnéades, por estender a dúvida indissolúvel a tudo, aderindo no final a um conhecimento limitado forjado através de um uso criterioso da razão e da experiência.

Além da consequência da tematização desta noção de ciência nos levar à maior aproximação do ceticismo sanchesiano, aquele vindo da academia cética, o fato de Sanches ter utilizado a expressão "parece-me" nos confirma a sua adesão no sentido fraco a uma crença. Ora, tanto pirrônicos quanto acadêmicos também partilham deste tipo de crença, que não assevera nada acerca da natureza das coisas, mas sim, cerca-se de motivos secundários que nos levam a fiar nossa confiança nelas. Como mostramos anteriormente, este é um quadro geral dos tipos de critério céticos da antiguidade. Estes ainda poderiam mais precisamente ser distinguidos pelo fato de os pirrônicos aderirem às aparências, de modo passivo, vivendo conforme seus instintos, as leis e os costumes. Enquanto os acadêmicos dariam sua aprovação a impressões que não são apreensivas, pois não apresentam a realidade inquestionavelmente, mas são plausíveis. Estas impressões são aceitas tal qual os fenômenos, tanto como critério de ação quanto como padrão de procedimentos teóricos. Porém, impressões plausíveis e aparências diferem pelo fato de o critério dos acadêmicos ser escolhido ativamente, através de uma análise criteriosa das impressões. Apesar de a expressão "parece-me", linguisticamente aproximar-se mais do jargão pirrônico, o quadro geral de seu uso parece nos indicar mais um ponto de toque entre o ceticismo acadêmico e o sanchesiano.

Inicialmente, referindo-se ao desconhecimento que Aristóteles revela sobre os princípios de sua ciência e à consequente ignorância que disso se segue acerca das coisas sujeitas a estes princípios, Sanches expressa a opinião de que a ciência é o conhecimento do assunto. Ainda assim, a perpétua dúvida, anteriormente exposta, acerca das palavras continua a nos rondar. De qualquer maneira, mesmo que a dúvida persista, Sanches define conhecimento como sendo "a compreensão, a penetração, o entendimento, e qualquer coisa, se houver, que signifique o mesmo."151 A sua própria suposição não pode passar incólume ao comentário

${ }^{151}$ SANCHES, F., Que Nada se Sabe, p. 85. 
diversas vezes feito acerca de outras noções de ciência: de ficções, só nascerão ficções. Assim, novamente, mesmo antes de esclarecer totalmente seu caminho, Sanches já o invalida no que concerne à universalidade e à necessidade que pretensamente se poderia lhe atribuir.

Para explicar melhor sua noção de ciência, Sanches apresenta-a num eixo tripartido: "a coisa a conhecer, o conhecimento, e a perfeição."152 Ou como tornará mais preciso no final do livro ${ }^{153}$, os três termos são "o assunto (res)", o "cognoscente (cognoscens)" e o "conhecimento 'perfeito", do qual Sanches trataria em uma obra vindoura, o tratado De Anima, que ou não escreveu ou se perdeu. De qualquer forma, o tratamento dado aos dois primeiros termos, o objeto e o sujeito, já mostrou que este último termo, o conhecimento perfeito, é inacessível para nós humanos, pois ele carece de um sujeito e de um objeto perfeitos, o que não há.

Antes de apresentarmos a análise sanchesiana, gostaríamos de apontar a semelhança do caminho seguido por Sexto Empírico no tratamento dado à questão dos tipos de critério da verdade nas Hipotiposes Pirrônicas. Em HP, II, 22 - 47, parágrafos correspondentes ao capítulo v, Sexto Empírico se refere ao homem, o critério "pelo qual" se julga. Em $H P$, II, 48 - 69, parágrafos relativos ao capítulo vi, tematiza-se o uso dos sentidos e do intelecto como critérios "através dos quais" se julga. Em $H P$, II, 70 - 79, parágrafos correspondentes ao capítulo vii, Sexto investiga o objeto como critério "em virtude do qual" se julga. Ora, aqui nos parece haver mais um ponto semelhante entre a argumentação de Sanches e a de Sexto Empírico, pois ambos consideram sujeito e objeto como partes integrantes do problema do conhecimento, que também é igualmente concebido por ambos como subordinado às duas outras partes anteriores. Os dez Tropos de Enesidemo, por exemplo, se referem às três partes. Em $H P$, I, 38 - 39, Sexto diz que os tropos se direcionam ao sujeito que julga, ao objeto julgado e à combinação de ambos. Os quatro primeiros Tropos se dirigem ao sujeito, pois quem julga é um homem, um animal ou um sentido e está em uma circunstância; o sétimo e o décimo se referem ao objeto; o quinto, o sexto, o oitavo e o nono são uma combinação de ambos. De modo geral, estes três grupos são subordinados ao Modo da relatividade, o décimo.

${ }^{152}$ SANCHES, F., Que Nada se Sabe, p. 88.

153 Ibid., p. 146. 
Como já dissemos, não podemos afirmar categoricamente que Sanches conheceu a obra de Sexto Empírico e que daí se apropriou de alguns elementos. No entanto a tripartição apresentada por Sanches possui os nomes e funções atribuídos às partes de forma semelhante à apresentada por Sexto Empírico. Pelo fato de considerar o conhecimento perfeito uma união entre a perfeição de sujeito e objeto, podemos associar Sanches a Sexto Empírico, que também faz um grupo de modos que se deriva da união dos dois grupos anteriores, também relativos ao sujeito e ao objeto.

Começa Sanches sua argumentação a partir dos objetos. Estes são infinitos, tanto individualmente, quanto no que tange às espécies. O procedimento abstrativo aristotélico de dividi-los em gêneros e espécies anulando suas particularidades não os descreve perfeitamente e nem elimina suas diferenças. Esta multiplicidade determina a nesciência preconizada por Sanches na medida em que ele não pode conhecer a infinidade dos objetos, e que seu interlocutor também não pode conhecer os objetos como finitos em número como supunha. Some-se ao problema da multiplicidade, o problema da possibilidade de a matéria e a forma das coisas também serem infinitamente múltiplas. Em seguida uma longa lista de outros argumentos é apresentada como parte de um ataque à possibilidade de conhecermos por completo a natureza dos objetos: a impossibilidade de conhecermos suas causas ou princípios primeiros; a confusão feita pelo mau uso das palavras e a pretensão de que elas tenham uma conexão direta com a natureza das coisas; a divisão entre as ciências com o intuito de tratar um único objeto específico por vez, quando na verdade, tudo se interconecta com tudo; a ausência de métodos certos nos quais o espírito possa tranquilamente permanecer para averiguar as coisas; a multiplicidade de culturas humanas; a inacessibilidade a lugares, objetos, culturas e animais devido aos limites espaço temporais; nossa incompreensão acerca do muito grande, o infinito, devido à nossa própria finitude; nossa incompreensão do muito pequeno, os acidentes; o caráter perpétuo da duração ou da geração ou da corrupção ou da mudança de determinadas coisas; as razões para determinada constituição dos seres e aquilo que permanece ou muda nesta constituição; as múltiplas propriedades da ação do calor sobre os seres; diferentes causas gerando mesmos efeitos e diferentes efeitos gerados pelas mesmas causas. Portanto, é vã a tentativa de conhecer os objetos. 
Ainda assim os sentidos são nossa fonte mais confiável de conhecimento. Estes, inclusive, são a fonte de material à qual a mente recorre para poder emitir seus julgamentos. Se os sentidos forem enganados, a mente também o será. A mente só vê as imagens das coisas, às quais teve acesso franqueado pelos sentidos. A partir destas imagens inquiri o objeto, mas nada consegue a não ser averiguar aquilo que é superficial. ${ }^{154}$ A natureza só se apresenta para nós desta forma: mostra-nos os seus contornos por trás de um véu ao qual não conseguimos perscrutar, somente contemplar à distância sem atingir sua real intimidade. Que se nos permita aqui uma longa citação, dado que nela Sanches estabelece algumas posições importantes:

A nossa razão julga das coisas por simulacros. Poderá por ventura ser exato seu juízo? Seria tolerável se obtivéssemos, por meio, dos sentidos, as imagens de todas as coisas que desejamos saber; ora, muito pelo contrário, das principais coisas não temos nenhumas. Só as temos dos acidentes que, segundo dizem, nada importam para a essência das coisas, da qual é a verdadeira ciência (...) É por isso que as coisas que são sensíveis, grandes, desprezíveis (e essas são os acidentes, e os compostos) de qualquer modo nos são conhecidas; e, pelo contrário, as que são espirituais, sutis, elevadas (e são essas os princípios dos compostos, e as coisas celestes) de nenhum modo nos são conhecidas.

No entanto, por natureza, são estas as mais cognoscíveis, por que são perfeitas, mais entes, mais simples, que são as três coisas que produzem o conhecimento perfeito. Não para nós, porque são mais afastadas dos sentidos, e as coisas que conhecemos melhor são as que lhes são mais próximas, e isto só pela razão de que o nosso melhor conhecimento depende dos sentidos, pois por natureza estas últimas são muitíssimo pouco cognoscíveis porque são imperfeitas, são quase nada. ${ }^{155}$

A imagem da natureza pintada por Sanches nos impõe esta situação na qual tentamos conhecê-la por meio de seus sinais superficiais. Muitas vezes somos privados até mesmo destes, o que prejudica mais ainda nossos julgamentos, sempre condicionados aos dados sensíveis. Assim, nossa ciência sempre é de segunda ordem, pois é feita acerca dos acidentes e não da natureza das coisas. $\mathrm{O}$ conhecimento perfeito das coisas, que é constituído pela simplicidade, perfeição e entidade das coisas não nos é acessível. Por simples entende-se a constituição à qual não pertencem vários elementos. Por perfeição entende-se o acesso completo e imediato ao todo da natureza de um ser. Por ente se entende "o objeto, o sujeito e o princípio de todo o conhecimento, e até de todos os atos e movimentos."156

\footnotetext{
${ }^{154}$ SANCHES, F., Que Nada se Sabe, p. 137

${ }^{155}$ Ibid., pp. 138 - 139.

156 Ibid., p. 138.
} 
Ao passar a tratar dos problemas relativos ao conhecimento, sendo este entendido como ato do cognoscente em relação ao objeto conhecido, Sanches o associa ao conhecimento da alma em suas faculdades e operações, que é o mais obscuro, nobre e difícil. Caso o conhecimento perfeito, isto é, completo e imediato, destas faculdades e operações da alma fosse acessível ao homem, este seria semelhante ao próprio Deus, "pois ninguém pode conhecer perfeitamente aquilo que não criou. Nem o próprio deus teria podido criar, nem governar as coisas que não tivesse conhecido previamente com perfeição."157 Em uma oportunidade anterior, Sanches nos explica nossa impossibilidade de conhecermos aquilo que é infinito, dado a desproporção que há entre este e nós, que somos finitos, e assim, pelo o fato de o compreendido ser maior do que aquele que o compreende, este não pode abarcar aquele. Assim, Deus conhece tudo, pois ele é máximo, supremo, onipotente, de modo que nem há a possibilidade de compará-lo com a infinidade de sua criação, imensamente menor do que Ele. O que se nos apresenta agora é o que se costuma chamar de "argumento do conhecimento do criador". É um tipo de argumentação também utilizado frequentemente por diversos filósofos com o intuito de moderar nossas pretensões cognitivas devido à nossa pequenez frente à imensidão da natureza. De certa forma este argumento pressupõe uma necessária conexão entre a potencia para criar e conhecer aquilo que se cria. Este argumento pressupõe, igualmente, uma espécie de identidade entre criador e criatura, restringindo a possibilidade de conhecimento à parte infinita desta relação, Deus, pois este é capaz de abarcar a criação, enquanto o processo inverso não é possível. É por isso que só Deus é "a sabedoria, o conhecimento, a inteligência perfeita, só ele penetra, sabe, conhece e entende todas as coisas, porque é tudo, e em tudo, e todas as coisas são nele." ${ }^{158}$ É por este tipo de hierarquia do conhecimento, na qual o homem se encontra em escala inferior, que não podemos conhecer nem às coisas ao nosso redor e nem a nós mesmos de maneira perfeita.

Perguntado pela definição de "conhecimento", parte integrante de sua definição de ciência como "conhecimento perfeito do assunto", Sanches mostra não estar livre do mesmo embaraço que apontou nas definições de ciência que criticou. O conhecimento é como a "apreensão do assunto", à qual se põe nova

${ }^{157}$ SANCHES, F., Que Nada se Sabe, p. 139.

158 Ibid., p. 140. 
questão. Neste caso, de interminável regresso ao infinito, que o próprio Sanches demonstrou em algumas oportunidades acerca de outras teorias, a recomendação é a de que o interlocutor apreenda por si mesmo tal definição. Caso persista a dúvida, e conforme o próprio Sanches, ela persistirá, o que se pode dizer é que "a intelecção é o conhecimento profundo, a intuição. Se insistires ainda acerca destes últimos termos, calar-me-ei, porque não posso nem sei responder." ${ }^{159}$ Mais uma vez, fortifica-se a visão anteriormente sustentada do ceticismo insuperável no pensamento de Sanches. Tal proposição de uma maneira de se entender a ciência não destoa do horizonte cético que Sanches tenta nos apresentar, pois ele não deseja "demonstrar" nada no sentido aristotélico, ao qual ele mesmo exerceu forte crítica, o que já havia deixado explícito no momento mesmo em que iniciou sua exposição. Além do mais, como já mostramos, esta concepção sanchesiana é uma tentativa que lhe parece apropriada, e não é aceita como inquestionável.

$\mathrm{O}$ argumento do conhecimento do criador tem uma profunda ligação com a argumentação cética e a delimitação de nosso conhecimento. Porém, como anunciamos acima, percebe-se em Que Nada se Sabe um adiantamento de fragmentos construtivos do pensamento de Sanches. Algumas coisas podem ser ditas acerca do conhecimento, em detrimento de nossa incurável ignorância da verdade. O conhecimento, diz Sanches, é a apreensão do assunto. Mas deve-se distinguir apreensão de recepção. A apreensão é a intelecção, o conhecimento profundo de algo. Ao passo que a recepção é o simples recebimento de informações sensíveis, coisa que até cães podem fazer. Devemos também distinguir o conhecimento próprio, que é a apreensão, do conhecimento impróprio, que é visto por Sanches nos termos de um reconhecimento de informações previamente memorizadas. E finalmente, devemos dividir todo o conhecimento em perfeito e imperfeito. O conhecimento perfeito é, novamente, a apreensão, da qual só Deus é capaz. O conhecimento imperfeito pode ser dividido em dois tipos: externo, que se obtém através dos sentidos; e interno, que se obtém pelo espírito, mas que é inferior ao conhecimento dos sentidos. ${ }^{160}$ É este conhecimento imperfeito o único que nos é acessível. Nele os sentidos apenas recebem impressões, as quais são oferecidas ao espírito para que este as julgue. Há ainda três espécies de coisas conhecidas de maneiras diferentes pelo espírito:

${ }^{159}$ SANCHES, F., Que Nada se Sabe, p. 141.

${ }^{160}$ Ibid., p. 111. 
as coisas externas, existentes sem auxílio do espírito e apresentam-se pelos sentidos; as coisas internas, que se dividem em coisas que carecem do espírito para existirem e em coisas que não carecem do auxílio do espírito para existirem, e se apresentam imediatamente, sem a intervenção dos sentidos; e finalmente, as coisas simultaneamente em parte externas e em parte internas, que apresentam-se em parte através dos sentidos e em parte sem a mediação destes.

Neste momento, curiosamente, o uso que Sanches faz do argumento do conhecimento do criador nos mostra algo novo. Não podemos compreender, ou nos termos de Sanches, apreender a nós mesmos, por não sermos nossos próprios criadores, pois não conseguimos acessar nosso interior. Resulta disso que toda vez que desejamos entender nossa vontade, nosso intelecto e nossa indiferença, por exemplo, estes sempre nos fogem e ficamos sem nada o que analisar. Assim, do ponto de vista da apreensão, nosso conhecimento externo é superior ao nosso conhecimento interno, pois naquele temos as imagens exteriores das coisas para analisarmos. Porém, extraordinária e inovadoramente Sanches distingue a apreensão da certeza. O que resulta na inversão do valor que acabamos de oferecer ao conhecimento externo e ao interno: "sob o ponto de vista da certeza, o conhecimento que temos das coisas externas por meio dos sentidos é vencido por aquele que temos das coisas que existem em nós, ou são feitas por nós". ${ }^{161}$

Continuando sua argumentação, agora mostrando os problemas relativos ao cognoscente, Sanches aponta sua constituição física como problemática para o conhecimento perfeito, além de apontar a sua formação cultural como algo igualmente problemático. Neste ponto ele fala da relação do aprendiz como seu mestre, a qual já abordamos quando falamos do ataque sanchesiano à autoridade.

Resta ao homem recorrer aos meios incertos, mas únicos restantes, que são a experiência e a razão. Os acadêmicos, sobretudo Carnéades, costumam ser associados à adesão a um probabilismo. Sexto Empírico em $H P, \mathrm{I}, 226$, diz que afirmam que algumas coisas são prováveis e outras improváveis. No entanto, Sexto define com poucos detalhes a doutrina de Carnéades. Em HP, I, 227, Sexto explica que o nível de probabilidade que uma ideia possui é medido por serem: "prováveis; e outras prováveis e contrastadas; e outras prováveis, contrastadas e não desconcertantes". Lembramos que, como dissemos anteriormente, Carnéades

${ }^{161}$ SANCHES, F., Que Nada se Sabe, pp. 113-114. 
distingue as impressões em apreensivas e não apreensivas, estas últimas podem, por sua vez, serem divididas em plausíveis e não plausíveis. Quanto maior o grau de verossimilhança conseguido através desta ponderação que parte da constatação de alguma probabilidade passando por testes, maior a aproximação desta impressão da verdade.

Há referências de Sanches a Carnéades na Carta a Clávio, onde Sanches saúda e se despede utilizando como codinome o nome do filósofo acadêmico. No entanto, nesta carta o probabilismo também não é tematizado, nem mencionado. $\mathrm{O}$ "parecer" verdadeira a sua definição de ciência, como indicamos, pode apontar uma adesão no sentido fraco via o pirronismo e o seu fenomenismo, ou via o ceticismo acadêmico e a noção de plausibilidade. Dado que a adesão de Sanches se dá ativamente, após uma ponderação cuidadosa, e ciente de seu caráter limitado e precário desde seus fundamentos, estas afirmações de Sanches ficam muito mais próximas de uma possível aceitação do probabilismo de Carnéades.

Sanches se refere poucas vezes à nossa restrição no estudo dos acidentes, o que nos levaria ao desenvolvimento do seu probabilismo. Em uma passagem de Que Nada se Sabe afirma que os acidentes são percebidos, mas sobre suas razões, assim como as das outras coisas, nada se sabe. No entanto os aristotélicos recorrem à distinção entre o que acontece por acidente e o que acontece por estar inscrito na essência de algo. Tal descrição é classificada por Sanches como "coisas prováveis"162 e não certas. Sanches promete voltar ao assunto. Noutra passagem, agora, acerca da variação entre nossas percepções sensoriais visuais, devido à veiculação das imagens em diferentes meios, tais quais o ar, a água e o vidro, Sanches diz que "apenas se podem fazer conjecturas, de que falaremos no Examen rerum" ${ }^{163}$. Desta vez, é à sua própria posição que Sanches atribui o caráter incerto, apesar de sua aceitação dele. Aqui não é utilizado o termo probabilidade ou termos etimologicamente familiares, mas conjectura é um termo, que está de alguma forma, semanticamente próximo à probabilidade, na medida em que alude a um julgamento aproximado, não corroborado por algum critério infalível. Posteriormente, Sanches explica que os sentidos, apesar de pouco apurados e confiáveis, são nossa mais segura fonte de conhecimento se comparados com a razão, estando esta duplamente condicionada por aqueles, pois

${ }^{162}$ SANCHES, F., Que Nada se Sabe, p. 105.

${ }^{163}$ Ibid., p. 116. 
neles deve se fiar para julgar e, no entanto não pode investiga-los amplamente para indicar os motivos destes. Tal quadro condiciona a razão, desta vez, a exercer sua função de julgar através de "probabilidades; e isto indefinidamente: nenhuma conclusão, dúvidas constantes." 164 Vimos então Sanches assinalar a probabilidade tanto aos discursos de seus adversários, quanto ao nosso uso dos sentidos e da razão. Anteriormente, quando comentávamos o uso da expressão "parece-me", vimos Sanches atribuir essa incerteza na aceitação de sua própria abordagem. Porém tal teoria não é desenvolvida detidamente no Quod Nihil Scitur além destas referências e da menção ao uso cuidadoso de razão e sensibilidade. Assim acreditamos poder atribuir a Sanches a posição de cético mitigado, que não supera o ceticismo, e ainda assim tenta se orientar com posições incertas às quais aceita sem, contudo, sustenta-las como verdadeiras. Seu processo de análise pela experiência e pela razão, que não é desenvolvido no Quod Nihil Scitur, aproximase, assim nos parece, da análise das probabilidades de uma impressão, tal qual proposta por Carnéades, na medida em que aspectos sensíveis e racionais são considerados na comparação entre as impressões quando se busca induzir motivos para que sejam gradualmente mais plausíveis. Novamente lembramos, no entanto, que o probabilismo de Sanches, devido ao recurso sanchesiano à experiência e ao juízo como ferramentas de ponderação para se alcançar um conhecimento declaradamente incapacitado de acessar a natureza das coisas, pode vir tanto de sua formação médica, que passou pelo galenismo, o qual também aceita probabilidades ao invés de conhecimentos necessários e universais, quanto de um contato com a doutrina acadêmica de Carnéades. Aqui, porém, tentamos nos ater às fontes propriamente filosófica de Sanches.

${ }^{164}$ SANCHES, F., Que Nada se Sabe, p. 122. 


\section{Conclusão}

É fácil percebermos que a busca pelo conhecimento representa para nós algo de ótimo proveito, independentemente da natureza do conhecimento em questão, pois o saber se faz necessário como ferramenta para a vida humana. A filosofia mesma, em toda a história de seu desenvolvimento, parece ter como seu mais íntimo motor tal inquietação cognitiva. Um dos grandes e definitivos capítulos da busca pelo saber certamente se deu com a formulação da posição filosófica do ceticismo, por volta do século III a. C., ainda na Antiguidade grega. Apesar de um longo período de esquecimento durante a Idade Média, tal postura filosófica foi resgatada a partir do conturbado ambiente cultural do Renascimento e reverberou fortemente na Modernidade. Esta retomada das estratégias de investigação desenvolvidas e compiladas pelos céticos não representa, no entanto, uma simples adesão passiva aos pressupostos do ceticismo antigo. Assim como na Antiguidade, também na Modernidade, a discussão cética apresentou novas características e desdobramentos teóricos conforme enfrentou os problemas encontrados em todas as tentativas de formulação de conhecimento acerca da natureza das coisas.

Os historiadores da filosofia, quase unanimemente, atribuem a René Descartes o mérito de ter dado o primeiro grande passo inovador e instaurador do modelo filosófico da Modernidade. O grande feito cartesiano teria sido o desenvolvimento de uma nova postura filosófica, a qual consiste na adoção de uma dúvida portadora de caráter preparatório, metodológico e hiperbólico. Esta inovação claramente revela um novo desdobramento da postura cética originada na Antiguidade. Em nossa avaliação há outro pensador, anteriormente a Descartes, ao qual poderíamos atribuir a posse de uma postura tal qual a cartesiana: Francisco Sanches (1551 - 1623), médico e filósofo português raramente citado nos manuais de história da filosofia. No entanto, diferentemente de Descartes, que acreditava ter superado a dúvida através do cogito, Sanches apresentou a dúvida cética como intransponível.

Além disso, acreditamos poder atribuir outro motivo de valorização ao 
pensamento sanchesiano. Sustentamos que o pensador lusitano desenvolveu de maneira pioneira em sua época aquilo que Richard Popkin chamou de "ceticismo construtivo ou mitigado". Este propõe a aceitação de um conhecimento limitado e incerto, circunscrito na esfera da interação entre nossas percepções sensíveis dos objetos e nossa capacidade de julgá-las. Tal rendição nos restringe a um conhecimento de segunda ordem, relativo não ao que é necessário e universal, mas sim ao que é contingente e particular. Esta seria nossa única possibilidade de conhecimento, dada a força dos ataques exercidos pela maneira cética de duvidar.

Para sustentar tais teses, recorremos inicialmente a um estudo acerca do ceticismo antigo, com vistas à determinação de quais são as linhas gerais que marcam a postura cética, já que nos interessa justificar o pertencimento de Sanches ao quadro do ceticismo. Mantivemos nosso estudo afastado de uma discussão, como a proposta por Sexto Empírico, sobre a propriedade da atribuição de uma postura realmente cética para pirrônicos ou acadêmicos. Acreditamos que apesar das diferenças encontradas em ambas as tendências, é possível traçar linhas fortes de continuidade entre a postura dos dois tipos de céticos.

Semelhantemente a David Sedley ${ }^{165}$, não definimos o ceticismo como o simples conjunto das expressões de dúvida e ignorância difundidas pelos filósofos gregos em geral, mas sim como o movimento filosófico que intitula a si mesmo como cético, e que se estende por cerca de cinco séculos, desde Pirro e Arcesilau no início do período Helenístico, até Sexto Empírico, convencionalmente localizado no final do segundo século da Era Cristã. Certamente aceitamos que existam manifestações de inquietação frente aos problemas do conhecimento anteriormente ao surgimento histórico do movimento cético, desde os présocráticos. Assim, podemos falar de um protoceticismo. Porém, é a escola cética que reúne tais inquietações num conjunto de estratégias para o teste sistemático de nossas pretensas aquisições de verdades. É também da postura cética que surge a atitude de suspensão dos juízos acerca da determinação da verdade ou da falsidade de nossas crenças. Estas são as linhas mais gerais que caracterizam a contribuição dos céticos: a escolha da problematização sistemática do conhecimento como método visando à suspensão de nossos juízos em questões práticas e teóricas. Conforme Sedley, nos protocéticos percebe-se que a consideração da

${ }^{165}$ SEDLEY, D., The Motivation of Greek skepticism. 
inacessibilidade momentânea ou permanente associa-se a "momentos mais sombrios". O que não ocorre no caso dos céticos, que tomam sua postura investigativa como redentora, tanto da inquietação espiritual causada pelo dogmatismo no caso dos pirrônicos, quanto da submissão às autoridades no caso dos céticos acadêmicos.

Ao buscarmos o nivelamento da argumentação cética da Antiguidade recorrendo a pontos comuns entre os céticos pirrônicos e os acadêmicos, inicialmente notamos o fato de que ambos utilizam como método de busca do conhecimento um tipo de argumentação dialética, que deliberadamente cria a tensão entre duas opiniões conflitantes acerca do mesmo objeto investigado e apresenta motivos para que não possamos decidir acerca deste problema. Ambos também aceitam a suspensão dos juízos como a atitude correta que sempre se segue a qualquer questão posta com relação às nossas percepções sensíveis e mentais, contra as quais fornecem argumentos. Na obra de Sexto Empírico temos a fonte mais rica e organizada destes ataques céticos à certeza. Alguns destes sistematizados em Tropos. Aparentemente o pirronismo tem nas suas fontes restantes a maior parte de argumentos reunidos e mais claramente expostos.

Os pirrônicos são mais explícitos acerca do caminho percorrido: aponta-se a diversidade de discursos acerca do mesmo objeto de conhecimento, a igualdade de força das razões sustentadas por estes discursos, a incapacidade de decisão sobre qual é o discurso verdadeiro e a consequente abstenção de julgamento sobre o problema posto.

Costuma-se atribuir aos acadêmicos uma ênfase maior no caráter subjetivo do conhecimento em detrimento do seu caráter objetivo. Aparentemente isto se dá, pois é nesta tendência cética que se considera mais enfaticamente a investigação sobre as nossas representações da realidade, como atestam, por exemplo, o argumento da embriaguez, o da loucura e o dos sonhos, encontrados no que restou do diálogo cético de Cícero, o Academica (Ac, II, 88-90). Já os pirrônicos, mesmo que não costumemos lhes atribuir tal abordagem à subjetividade, aparentemente consideram a interioridade do sujeito, pois esta é tematizada por Sexto Empírico em uma análise tripartida do problema do conhecimento, onde o objeto, o sujeito e as possibilidades de relação entre ambos são problematizados (HP, II, V-VII). Além disso, Sexto Empírico também suscita a dúvida através da problematização tanto da constituição do sujeito, quanto das 
possíveis circunstâncias nas quais se insere aquele que julga. Isto acontece, por exemplo, no Quarto Modo voltado para a suspensão (HP, I, 100 - 117), onde Sexto analisa as diferentes circunstâncias nas quais os humanos se encontraram e discute o condicionamento exercido pelos estados, naturais ou não naturais, sobre nossa capacidade de julgar de forma unívoca. Assim como Cícero, Sexto expõe a diferença de julgamento entre alguém em delírio e alguém são, entre o acordado e aquele que dorme, entre o sóbrio e o ébrio, dentre outras várias oposições que nos afetam, tais como sermos jovens ou maduros, saudáveis ou adoentados, apaixonados ou afetados pelo ódio, confiantes ou amedrontados, estressados ou relaxados, parados ou em movimento, famintos ou saciados. Sexto volta a este tema e novamente tematiza a loucura e o sono, além da juventude, em Contra os Lógicos, quando discute o ataque de Protágoras de Abdera ao critério ( $A M$, VII, 60 - 64). Podemos notar, contudo, que Cícero parece fazer um uso mais proveitoso destes problemas, pois além de usá-los para propor a suspensão dos juízos, também indica através deles que não há uma distinção entre impressões verdadeiras e falsas quando assentimos de forma dogmática.

As escolas pirrônica e acadêmica também se identificam no que tange à solução que apresentam para a falta de respostas inequívocas para o impasse criado pela argumentação de cunho cético. Tanto pirrônicos quanto acadêmicos aderem a uma crença fraca, na qual a pretensão de ter estabelecido a verdade está ausente dos seus assentimentos.

Porém, as soluções das duas correntes céticas variam. Os pirrônicos recorrem ao fenômeno, às aparências, sejam sensíveis ou mentais. Eles aceitam passivamente as aparências providas pelos instintos, pelas leis e pelos costumes, como forma de solucionar o impasse cético no que tange à vida prática e às questões filosóficas. Por sua parte, os céticos acadêmicos aceitam aquilo que chamam de impressões plausíveis ou persuasivas. Estas são o critério acadêmico de decisão frente à necessidade prática e teórica de posicionar-se a despeito da dúvida intransponível. O plausível, por sua vez, é um posicionamento ativo frente à dúvida, atingido através do uso circunspecto das sensações e da razão.

Ambos os tipos de céticos declaram-se debatedores que buscam seu mote na crítica ao pensamento formulado por outras escolas, as quais frequentemente se pronunciam sobre aquilo que não lhes é suficientemente conhecido. Os pirrônicos, de forma mais explícita, afirmam que investigam o que se diz das aparências, não 
as aparências mesmas. Entra em cena uma diferença de objetivo entre estas correntes céticas. Os pirrônicos, no seu afã de livrar-nos das crenças irrevogáveis e da investigação dogmática, sem nos desesperar da busca pela verdade, pretendem empreender igualmente a sua busca terapêutica pela felicidade, que se manifesta na tranquilidade após o cessar da nossa adesão ao dogmatismo. Já os acadêmicos buscam garantir a liberdade dos nossos julgamentos frente às autoridades, sejam estas representadas pelos nossos sentidos, pela nossa razão, ou por célebres pensadores. Esta liberdade nos possibilitaria prosseguirmos em nossa investigação, guiados pela razão, nos permitindo aproximarmo-nos ao máximo da verdade.

A despeito da ênfase posta por alguns comentadores sobre as diferenças entre o pirronismo e a doutrina acadêmica, é importante notar que as duas escolas atribuem caráter existencial e prático a toda a problemática que elas desenvolvem teoricamente. A ideia de uma skeptiké agogé nomeia tal postura. Esta condução cética não dissocia as decisões intelectuais das mais simples decisões práticas, numa tentativa de estabelecer a possibilidade de uma vida pautada pelo ceticismo filosófico. De um modo geral, estes nos parecem ser os traços comuns entre pirrônicos e acadêmicos. Acreditamos que tais características exercem um papel fundamental na delimitação daquilo que foi o ceticismo na Antiguidade. Assim, apesar da querela entre pirrônicos e acadêmicos, somos levados a crer que ambos podem ser subsumidos como habilidosos argumentadores in utranque partem, que buscam estabelecer a suspensão dos juízos e viver uma vida baseada em crenças não dogmáticas. Evidentemente este é um contorno geral, mas nos parece bastante adequado e abrangente quando se analisa o desenvolvimento da corrente cética na Antiguidade.

Durante a Idade Média as fontes textuais do ceticismo foram esquecidas. Sendo quase inexistentes as cópias e referências a elas. Até mesmo o vocábulo "cético" e seus cognatos eram inexistentes na língua latina até o século XV. No entanto, nota-se alguns pensadores trilhando uma tendência de pesquisas lógicas e epistemológicas de cunho bastante crítico, que se aproxima da postura cética dos antigos. Porém, além de não podermos filiá-los ao legado textual dos céticos antigos, também não podemos indicá-los como descendentes diretos desta escola, dados a procedência e os fins religiosos dos integrantes do protoceticismo moderno. Discute-se a real relevância da retomada dos textos céticos da 
Antiguidade durante o Renascimento. Existe o consenso, no entanto, de que foram amplamente divulgados e revisitados durante o século $\mathrm{XV}$, momento da renovação cultural que prenuncia diversos acontecimentos importantíssimos como a Descoberta das Américas, a Reforma Protestante e Revolução Científica do século XVII. O que nos permite atribuir um grande papel para o ceticismo na formação do pensamento filosófico da Modernidade.

As possíveis razões que encontramos para tão longa ausência destes textos são o fato de o grego não ter ser sido comumente conhecido durante a Idade Média nem mesmo pelas pessoas educadas, a conjunção entre um forte senso realista e a centralização das questões epistemológicas em torno da Bíblia e o forte ataque feito por Santo Agostinho ao ceticismo acadêmico no diálogo Contra Acadêmicos. Estas nos parecem boas razões de cunho linguístico, filosófico, teológico e epistemológico. Suficientes para tentar explicar a ausência dos textos e da continuidade da tradição cética entre os séculos V e XV da Era Cristã.

Pouco nos restou dos textos céticos antigos. Basicamente, o que temos de mais relevante são: as obras de Sexto Empírico, Hipotiposes Pirrônicas e Adversus Mathematicos, que consistem em uma compilação de argumentos e uma demonstração de ataques céticos às diversas tentativas de formulação de conhecimento; O diálogo Academica, de Cícero, onde o autor latino tenta expor e defender a doutrina da Academia cética; e a Vida de Pirro, um capítulo constituinte das Vidas dos Filósofos Ilustres de Diógenes Laercio, que apresenta testemunhos sobre a vida e o pensamento de Pirro.

O diálogo ciceroniano é a única fonte que esteve presente desde a Antiguidade de forma constante, mesmo que com pouquíssima relevância. $\mathrm{O}$ diálogo agostiniano supracitado obtém muito mais atenção do que o próprio Academica. A primeira edição impressa deste e de outros textos de Cícero data de 1471. Somente em 1531 surge na Itália um texto que mostra preocupar-se com o diálogo de Cícero. Porém, são preocupações filológicas e não filosóficas que dão origem a este interesse. É curioso que autor tão relevante para o currículo desde a Idade Média, como é o caso de Cícero, seja seletivamente consultado. Podemos, no entanto, conjecturar que por ser considerado um grande homem das letras, o homem medieval e renascentista teria tido dificuldades para conciliar esta imagem e a figura iconoclasta contida no Academica. Somente no final do século XVI 
surge escasso interesse por este diálogo, que novamente sofreu tentativas de refutação e foi utilizado como ferramenta pela a postura fideísta.

A obra de Diógenes Laercio Vidas dos Filósofos Ilustres foi traduzida para a língua latina pela primeira vez em 1430, por Ambrogio Traversari. Esta tradução circulou amplamente pela Itália em forma de manuscrito sendo reproduzida em dezenas de outros manuscritos, além de ter recebido algumas traduções para o italiano. Em 1472 ganhou sua primeira impressão. Esta é uma obra complementar para o estudo da filosofia antiga, na medida em que ela é o primeiro manual de desenvolvimento histórico de escolas filosóficas na Antiguidade. O capítulo que mais ricamente trata do ceticismo é a Vida de Pirro, o qual parece ter sido desconhecido durante a Idade Média. É digno de nota o fato de a palavra scepticus parecer ter sido introduzida na língua latina através desta tradução e gradualmente, até o fim do século XVI, ter firmado sua existência no vocabulário comum.

Em 1427 manuscritos de Sexto Empírico são levados para a Itália. A partir daí percebe-se indícios de interesse dos humanistas por estes textos, os quais passam a constar no catálogo de algumas das maiores bibliotecas da época. Entretanto, inicialmente este interesse parece ter ênfase histórica e filológica. Em 1520, Gianfrancesco Pico della Mirandola publica seu Examen Vanitatis, que parece ser a primeira obra a demonstrar real interesse filosófico pelo legado cético presente em Sexto Empírico. A primeira tradução de Sexto que causa algum impacto no ambiente intelectual surge em 1562, em Genebra, quando Henri Estiene publica as Hipotiposes Pirrônicas, incluindo como apêndice a Vida de Pirro, de Diógenes Laercio, e De Optimo docendi genere liber, de Galeno. Em 1569 surge a primeira tradução completa de Adversus Mathematicos, feita por Gentian Hervet, que inseriu a tradução das Hipotiposes Pirrônicas feita por Estiene como apêndice à sua publicação.

É no contexto culturalmente conturbado do Renascimento e de retomada do ceticismo que Francisco Sanches é formado. Gentian Hervet, por exemplo, ensinou grego no Collège de Guyenne, em Bordeaux, anos antes de Sanches frequentar esta instituição como um aluno. Esta instituição parece ter sido permeável, mesmo que nem sempre tolerante, à influência de ideias reformistas e renascentistas. Aqui Sanches aprendeu grego, latim, teve contato com a retórica ciceroniana e com a lógica e a física aristotélicas. Posteriormente, o jovem 
português se dirige para a Itália, em direção aos grandes centros renascentistas, como Pisa, Pádua, Veneza, Ferrara e Florença. Sanches buscava tornar-se médico. O currículo ao qual se submeteu incluía estudos filosóficos concomitantemente com o estudo da medicina. A estadia na Itália lhe forneceu contato com a obra de Galeno e com algumas críticas tanto desta como da obra de Aristóteles. A partir do contato com Galeno e com a Itália renascentista Sanches também é ensinado a valorizar a observação da natureza nos estudos médicos. De volta à França, Sanches obtém seu doutorado em medicina na universidade de Toulouse. Deve-se notar que nestes anos de formação Sanches moldou seu caráter crítico, autônomo e preconizador da experiência direta da natureza.

O filósofo e médico português envolveu-se seriamente com a produção de estudos médicos e a prática da medicina. Sua produção filosófica genuína localiza-se entre 1574 e 1581, quando ainda não havia conseguido nenhuma nomeação para função médica. Em 1578 publica seu primeiro trabalho filosófico, O Cometa do Ano de 1577, no qual combate as previsões que assolaram a Europa após a passagem de um cometa. Em 1581 publica Que Nada se Sabe, onde se manifesta sua intenção de usar a discussão filosófica sobre as possibilidades de uma investigação científica como maneira preparatória para a formulação de conhecimento na medicina. Nesta obra se apresentam as características que acreditamos fazerem de Sanches uma figura de relevo, digna de nossa atenção. Por um lado, um herdeiro do ceticismo antigo, ao retomar seus problemas e suas estratégias argumentativas. Por outro lado, um dos genitores do ceticismo moderno, pela utilização metodológica e hiperbólica da dúvida, que é concebida como insuperável, e pela formulação de um ceticismo mitigado como resposta à dúvida.

É o Que Nada se Sabe que nos permite inserir Sanches no quadro da retomada do ceticismo. Demonstramos através de várias referências textuais que, após decepcionar-se com a falsidade percebida em diversos momentos nas bases de sua formação, surge a decisão sanchesiana de não mais aceitar como verdade nada que não fosse percebido por sua própria análise das coisas, livremente das pretensas autoridades de onde vieram os saberes postos em questão. Associamos este ímpeto libertador de todas as possíveis autoridades percebido em Sanches ao seu conhecimento sobre o ceticismo acadêmico, que tinha como finalidade não a tranquilidade pirrônica, mas sim a manutenção da autonomia intelectual. Sabemos 
que o contato com os textos galênicos também podem ter parte na formação desta postura sanchesiana. Porém, preferimos não abordar as fontes médicas do pensamento de Sanches, nos restringindo aqui às suas fontes filosóficas. Além de apontar esta interseção com os acadêmicos, também mostramos que Sanches utiliza o método dialético cético na construção de uma dúvida insuperável, à qual se segue a suspensão dos juízos. Isto lhe põe no quadro geral do tipo de argumentação vindo do ceticismo antigo, tanto na matriz pirrônica quanto na acadêmica.

Esta dúvida, contudo, é concebida de maneira tão expansiva que é apresentada como impassível de superação. Determinamos com estes dados uma semelhança e uma diferença entre Sanches e Descartes: eles se aproximam pelo fato de utilizarem deliberadamente a dúvida universal como filtro de nossas crenças; e se diferenciam por Sanches não conceber que a dúvida possa ser superada. Este foi um dos passos iniciais e mais importantes de nossa pesquisa, dado que cumpre um de nossos objetivos, que consiste em mostrar justamente a adoção do ato de suspender o juízo sobre a validade de todo o conhecimento como ferramenta para julgar mais apropriadamente a verdade ou a falsidade de algo. Acreditamos que assim Sanches antecipa o passo cartesiano da dúvida metódica e hiperbólica, tão genuinamente moderno.

Após instaurar a dúvida de uma forma geral, Sanches utiliza seu arsenal cético contra três tentativas determinadas de definição do que é a ciência. $O$ ataque à noção platônica de ciência como reminiscência, e às noções aristotélicas de ciência como conhecimento através das causas e como hábito adquirido por demonstração, nos parecem exercícios da dúvida contra dois dos maiores pilares da tradição. Atacando Platão, Sanches teria criado elementos para negar que a memorização seja o cerne da produção de conhecimento. Este objetivo parece ter sido intentado também na crítica a Aristóteles, o mais influente dos filósofos antigos naquele momento, e que não parecia ser analisado, mas somente decorado. Além disso, toda a abstração do silogismo é mordazmente criticada por um nominalismo que nos impõe a volta à análise direta das coisas para conhecê-las, o que elimina a ideia de uma ciência nos moldes da universalidade. Sanches também demonstra a impossibilidade de conhecermos as causas das coisas como forma de sustentar que, apesar de grandemente dotado, o intelecto de Aristóteles algumas vezes enveredou-se pelo caminho do erro e em outras tantas foi limitado. 
Em nossa avaliação, a formulação e a refutação de uma versão própria de ciência por parte Sanches representa o maior golpe que ele poderia dar no dogmatismo que tanto combatia. Isto se dá porque a noção de ciência cunhada por Sanches consiste naquilo que é mais fundamental para todo o dogmatismo possível. Isto é, a pretensão de que se pode chegar à essência da realidade de maneira completa e imediata. É isso o que propõe a noção sanchesiana de ciência como o conhecimento perfeito do assunto. Na tentativa de refutar tal pretensão, Sanches dá espaço à análise tripartida do problema do conhecimento, tal qual já mencionamos. Este ponto é decisivo para nossa tentativa de avaliar um pouco mais o ceticismo de Sanches. Podemos agora avaliar como Sanches concebe nossos mais próprios limites e possibilidades cognitivas, e a solução filosófica dada para a dúvida cética. Além disso, ainda podermos avaliar se Sanches tende mais para a linhagem pirrônica ou acadêmica ao retomar o ímpeto cético.

A tripartição do problema do conhecimento, que apontamos em Sexto Empírico, nos parece a semelhança argumentativa mais patente entre Sanches e o compilador cético da Antiguidade. Sanches anuncia, de modo explícito, tal divisão como parte dos passos de sua argumentação na sua obra sobre a qual nos debruçamos. Esta divisão não é tematizada da mesma forma no Academica. Em $H P$, II, V-VII, se estabelece que: o sujeito humano, aquilo pelo qual os objetos são julgados, não pode ser totalmente conhecido; os sentidos e o intelecto, aquilo através do qual os objetos são julgados, são destituídos de capacidade para julgarem por si mesmos ou numa interação entre ambos; e as aparências, aquilo em virtude do qual os objetos são julgados, apesar de não serem totalmente convincentes, são nosso único meio de julgar os objetos, pois não podemos acessar estes de maneira direta e imediata nem pelos sentidos, nem pelo intelecto.

Sanches, por sua vez, também concebe o sujeito como não sendo capacitado para conhecer a si mesmo exaustivamente por diversas razões que se aproximam de alguns dos argumentos utilizados nos Modos céticos contidos em Sexto. Para além deste compilador cético, Sanches apresenta outros argumentos para nossa incompreensão de nós mesmos: só pode conhecer algo aquele que o cria, portanto estamos condenados a não nos entendermos por completo, o que conhecemos como o argumento do criador; e podemos ter mais certeza sobre a existência de nossa interioridade do que podemos compreendê-la, pois é inversamente mais fácil compreender o mundo externo do que ter certeza sobre a 
existência deste. Acreditamos que neste segundo argumento, Sanches parece desenvolver aquele que é um dos novos questionamentos céticos surgidos na Modernidade, o problema do mundo exterior. Contudo, não há uma discussão detida de tal problema no seguimento do texto estudado.

Sanches também considera nossos sentidos, nosso intelecto e a interação entre ambos tanto como parte do problema do conhecimento, quanto como nossas ferramentas para o conhecimento. Contudo estas são ferramentas imprecisas e limitadas, novamente sujeitas a alguns dos argumentos que também podem ser encontrados no desenvolvimento dos Modos céticos por Sexto. Em terceiro lugar, os objetos a serem conhecidos também são condenados. Semelhantemente a Sexto, Sanches sustenta que eles só podem ser julgados através de suas qualidades superficiais e secundárias, e nunca por si mesmos, além de interpor diversas outras dificuldades vindas da natureza dos objetos e do sujeito, algumas das quais também podem ser encontradas em Sexto.

Como solução para o impasse de estarmos privados do conhecimento da natureza em sua intimidade, Sanches propõe um conhecimento limitado e incerto. Contudo, este é o único tipo de conhecimento que podemos acessar. Um conhecimento que se gera a partir de tentativas de julgar de modo cuidadoso e crítico as informações sensíveis que recebemos dos objetos reais. Assim, estamos restringidos a saber aquilo que nosso obtuso intelecto infere cautelosamente a partir de nossos múltiplos e variáveis estímulos sensíveis provindos das coisas que investigamos. Acreditamos que tal solução seja uma reapresentação do caminho escolhido por Carnéades. Lembremos que no Academica se apresenta Carnéades como quem propôs o uso circunspecto do juízo direcionado às nossas representações como forma de se encontrar impressões persuasivas, que não são absolutamente verdadeiras, mas nos oferecem graus variados de certeza aproximada aos quais podemos aceitar de modo aberto e não dogmático. A nosso ver, este é o ponto no qual o ceticismo de Sanches marca claramente sua procedência. Há, contudo, o problema das fontes textuais.

O Quod Nihil Scitur não faz nenhuma referência ou citação direta das duas maiores fontes textuais do ceticismo antigo, Sexto e Cícero. Entretanto, este texto sanchesiano menciona outras fontes que poderiam lhe fornecer farto material acerca do escopo teórico tanto do ceticismo pirrônico quanto do acadêmico. Diógenes Laercio, Pico della Mirandola, Galeno e Plutarco, que são citados, 
cumprem tal tarefa. Diversas razões podem ser conjecturadas para sustentar que Sanches teria tido acesso direto a Sexto e ao Cícero acadêmico. Todas elas ficam no campo da suposição, pois sem a citação direta, não há dados bibliográficos ou textuais suficientemente verificáveis que fundamentem tal contato.

Bernard Besnier ${ }^{166}$ diz que Sanches poderia ter conhecido a tripartição do problema do conhecimento a partir dos capítulos I-XIX e XXXII-XXXVI do Examen Vanitatis de Pico della Mirandola. Este comentador, por exemplo, está no grupo daqueles que não consideram Sanches um pirrônico. Besnier acredita que as maiores preocupações de Sanches eram, primeiramente, destituir o aristotelismo de sua posição de instrutor em questões de investigação da natureza e, em segundo lugar, manter distância daqueles que tentassem substituir o aristotelismo.

Como já dissemos, o ímpeto de debater dialeticamente in utranque partem e a suspensão dos juízos que segue a investigação afetam tanto os pirrônicos quanto os acadêmicos. Estas características, também fortemente presentes em Sanches, poderiam ter sido adquiridas a partir de todas as fontes antigas citadas no Que Nada se Sabe. Elas possuem diversos argumentos reutilizados por Sanches.

No decorrer de nossa análise das citações feitas por Sanches percebemos que o Contra Colotem de Plutarco facultaria a Sanches o acesso somente ao pensamento de Arcesilau. Numa certa passagem onde os acadêmicos são citados, Sanches menciona outro texto de Plutarco como referência, o Lucullus. Ora, não se encontram neste texto dados sobre a teoria acadêmica, mas somente pouquíssimos dados biográficos sobre Carnéades, Philo e Cícero. Logo, propusemos a hipótese de ter havido um erro tipográfico e o Lucullus citado nesta oportunidade não ser o de Plutarco, mas sim um dos livros restantes do Academica. Apesar de conjectural, este nos parece o maior argumento para fundamentar que Sanches tenha lido o Academica, pois este texto parece ser a fonte mais apropriada para acessar o pensamento de Carnéades.

Por nossa parte, acreditamos que Sanches não era somente antiaristotélico, nem tinha pretensões a assumir o lugar de Aristóteles. Sanches nos parece um cético convicto, que combate o aristotelismo como mais uma tarefa de sua missão de destituir de valor qualquer discurso dogmático, pois este é um entrave para a observação direta e livre da natureza. A respeito desta tarefa, Sanches ainda nos

${ }^{166}$ BESNIER, B., Sanchez à Moitié Endormi, pp. 105-106. Nota 12. 
apresenta seu intuito de utilizá-la como parte da sua busca de um caminho seguro para o desenvolvimento mais apropriado daquela ciência que lhe interessa mais proximamente, a medicina. Isto não inclui, no entanto, a suposição de seu caminho como um ambiente repleto de certezas fáceis, universais e inequívocas. Afiliando-se ao ímpeto cético acadêmico, Sanches deseja estabelecer um método de investigação que inclua a análise intelectual das informações de nossa experiência sensível como o meio para adquirirmos conhecimentos de cunho aproximado, sobre aspectos superficiais da natureza, não sobre suas essências. Além desta opção teórica para solucionar o problema do critério, ainda possuímos outra razão forte para crermos que há uma tintura da academia cética por trás de suas palavras do Quod Nihil Scitur: na sua saudação e na sua despedida em uma carta ao matemático alemão Cristovão Clávio, Sanches se intitula pelo codinome de "Carnéades". A qualificação de "un grand Pyrrhonien" atribuída a Sanches por Pierre Bayle nos parece equivocada. Acreditamos mais apropriada a aproximação de Sanches com o ceticismo acadêmico e a tendência mitigada desenvolvida por Carnéades.

Caso sigamos quadros comparativos gerais entre o ceticismo antigo e o moderno $^{167}$, acreditamos poder identificar Sanches como um dos patronos da Modernidade filosófica. Primeiramente, diferentemente dos antigos que centralizam a argumentação cética em torno da noção de epoché, os modernos apresentam atenção maior para o uso metodológico da dúvida, como primeira etapa da investigação. Este último é o caso de Sanches. Enquanto a investigação cética na Antiguidade não dissociava teoria e ação prática, na Modernidade acontece a dissolução entre a abstração e a vida comum, como forma de garantir a pureza do espírito crítico. Aqui também enquadramos Sanches entre os modernos, pois somente em dois momentos ele faz afirmações de cunho ético: no início da Carta ao Leitor, em Que Nada se Sabe, quando diz que "a poucos é dado o saber querer"168; e quando afirma, em uma nota marginal ao texto da obra supracitada, que "a ignorância merece o perdão; a falácia o castigo."169 Nas duas oportunidades, Sanches somente pronuncia uma crença prática sem problematizá-

${ }^{167}$ Ver BICCA, L., Ceticismo, Crença e Conhecimento. In: BICCA, L., Ceticismo e Relativismo. Rio de Janeiro: 7 letras, 2012. pp. 133 -159. Ver Também MARCONDES, D., Ceticismo, Filosofia Cética e Linguagem. In: SILVA FILHO, W. J., (Org.) O Ceticismo e a Possibilidade da Filosofia. Ijuí: Editora Unijuí, 2005. pp.135-158.

${ }^{168}$ SANCHES, F., Que Nada se Sabe, p.63.

${ }^{169}$ Ibid., p.72. 
la. Continuando nosso quadro comparativo, os primeiros céticos davam ênfase ao seu caráter dialético e argumentativo, enquanto os céticos modernos concentravam-se nos problemas epistêmicos relativos à possibilidade do conhecimento. Novamente Sanches acopla-se ao conjunto dos modernos. Podemos ainda citar o problema do mundo exterior, que é tido como inexistente na Antiguidade e presente na Modernidade. Como mostramos, Sanches parece apontar para este problema antes mesmo de Descartes.

Acreditamos ter reunido até aqui elementos suficientemente plausíveis para reavivar o vulto filosófico de Francisco Sanches, apresentando-o como um herdeiro da argumentação do ceticismo antigo e inserindo-o no quadro da retomada criativa desta tradição feita pela filosofia moderna, apesar deste pensador lusitano pertencer cronologicamente ao período do Renascimento. 


\section{Referências biliográficas}

ALGRA, K., BARNES, J., MANSFELD, J. \& SCHOFIELD, M. (eds.) The Cambridge History of Hellenistic Philosophy. Cambridge: Cambridge University Press, 2009.

ALMEIDA, O. T. Francisco Sanches - o "Elo Perdido" entre os Descobrimentos e a Ciência Moderna. In: Cultura - Revista de História e teoria das Ideias. Lisboa: Universidade de Lisboa, Separata, Vol. XII (2º́rie), 2000 2001.

ANNAS, J. \& BARNES, J. The Modes of Scepticism. Cambridge: Cambridge University Press, 1985.

ARISTÓTELES Ética a Nicômaco. Tradução de Leonel Vallandro e Gerd Bornheim. São Paulo: Abril Cutural, 1979. In: Col. Os Pensadores.

Categoriae and De Interpretatione. In: ROSS, W. D. (ed.) The Works of Aristotle. Vol. Oxford: Claredon Press, 1928.

Analytica Priora. In: ROSS, W. D. (ed.) The Works of Aristotle. Vol. Oxford: Claredon Press, 1928.

Analytica Posteriora. In: ROSS, W. D. (ed.) The Works of Aristotle. Vol. Oxford: Claredon Press, 1928.

Topica and De Sophisticis Elechis. In: ROSS, W. D. (ed.) The Works of Aristotle. Vol. Oxford: Claredon Press, 1928.

AZEVEDO, A. Da Epistemologia e Metodologia de Francisco Sanches. Lisboa: Instituto Piaget, 2006.

BARNES, J. The Toils of Scepticism. Cambridge: Cambridge University Press, 1990.

BAYLE, P. Dictionnaire Historique et Critique - tome treizième. Paris, 1820.

BESNIER, B. Sanchez à Moitié Endormi. In: MOREAU, P.-F. Le Scepticisme au XVIe et au XVIIe Siécle. Paris: Éditions Albin Michel, 2001. pp. 102-120.

BETT, R. Carneades' Pithanon: A Reappraisal of its Role and Status. In: ANNAS, J. (ed.) Oxford Studies in Ancient Philosophy - vol. VII. Oxford: Oxford University, 1989. pp.59-94.

Carneades' Distinction between Assent and Approval. In: Monist 73, 1990. pp.3-20. 
Scepticism and Everyday Attitudes in Ancient and Modern Philosophy. Metaphilosophy 24, 1993. pp. 363-381.

(ed.) The Cambridge Companion to Ancient Scepticism. Cambridge: Cambridge University Press, 2010.

BICCA, L. Ceticismo e Relativismo. Rio de Janeiro: 7 letras, 2012.

Ceticismo, Crença e Conhecimento. In: BICCA, L. Ceticismo e Relativismo. Rio de Janeiro: 7 letras, 2012. pp. 133 -159.

A questão do alcance e da radicalidade do ceticismo antigo. In: Ensaios Filosóficos, Volume VIII - Dezembro/2013, pp. 69-99.

BOLZANi FILHO, R. A Epokhé Cética e Seus Pressupostos. In: Sképsis, n 3-4, 2008. pp. 7-27.

Acadêmicos versus Pirrônicos. In: Sképsis, ano IV, $\mathrm{n}^{\circ} 7$,

2011. pp. 5-55.

Estratégias Modernas de Abordagem Crítica do

Ceticismo Antigo. In: Trans\Form\Ação, Marília, v. 34, no 3, 2011. pp. 89-104.

Acadêmicos versus Pirrônicos. São Paulo: Alameda,

2013.

BROCHARD, V. Os Céticos Gregos. São Paulo: Odysseus, 2009.

BROITMAN, M. S. Francisco Sanches y el Redescubrimiento de la Duda en el Renacimiento. Newark: Juan de La Cuesta, 2011.

BUNYEAT, M. F. (ed.) The Skeptical Tradition. Berkley: University of California Press, 1983.

Carneades was no Probabilist. (artigo não publicado).

Explorations in Ancient and Modern Philosophy. (vol. 1) Cambridge; New York: Cambridge University Press, 2012.

BURNYEAT, M. F. \& FREDE, M. (eds.) The Original Sceptics: A Controversy. Indianapolis: Hackett, 1997.

CALAFATE, P. O Conflito Entre a Filosofia e a Retórica na Obra de Francisco Sanches. In: Revista Portuguesa de Filosofia, T. 51, Fasc. 3/4, Filosofia em Portugal — VIII (Jul. -Dec., 1995), pp. 417-426.

CALUORI, D. The Scepticism of Francisco Sanchez. In: Archiv für Geschichte der Philosophie 89 (2007) p.30-46. 
CANTISTA, M. J. Crítica do Saber Tradicional e Cepticismo na Época dos Descobrimentos: A Obra de Francisco Ribeiro Sanches (1551 - 1623). In: Revista da Faculdade de Letras - Filosofia", Porto, 2.a série, 7, 1990, p. 115-123.

CAO, G. M. The prehistory of modern scepticism: Sextus empiricus in fifteenthcentury Italy. In: Journal of the Warburg and Courtauld Institutes 64, 2001. pp. 229-80.

CAVAILLE, J.-P. Le Retour des Sceptiques. In: Revue Philosophique de la France et de l'Étranger, T. 188, No. 2, Philosophie Grecque. Avril-Juin, 1998. pp. 197-220.

CAZAC, H.-P. Le lieu d'origine et les dates de naissance et de mort du philosophe Francisco Sánchez. In: Bulletin Hispanique. Tome 5, N4, 1903. pp. 326-348.

Le philosophe Francisco Sánchez le Sceptique (1550-1623) et les maisons galiciennes de Castro. In: Bulletin de l`Académie Royale de l'Hitoire, 53 (jul. - sep. 1908). pp. 55-119.

CICERO, M. T. On Academic skepticism. Translated by Charles Brittain. Indianapolis/Cambridge: Hackett Publishing, 2006.

COPENHAVER, B.P. \& SCHMITT, C. B. Renaissance Philosophy. Oxford: Oxford University Press, 1992.

COPLESTON, F. A History of Philosophy, vol. III - Late Medieval and Renaissance Philosophy. New York: Image Books, 1993.

DESCARTES, R. Discurso do Método. São Paulo: Abril Cultural, 1979. In: Col. Os Pensadores.

Pensadores. Meditações. São Paulo: Abril Cultural, 1979. In: Col. Os

DÍAZ, G. D. Hombres y Documentos de la Filosofía Española, Volume 7. Madrid: Centro de Estudios Históricos, C.S.I.C., 2003.

DOBARRIO, F. S. Francisco Sanches y El escepticismo de su Tiempo. Madrid: Universidade Complutense de Madrid/ Caixa Ourense, 1985.

EMPIRICUS, S. Against the Logicians. Translated and edited by Richard Bett. New York: Cambridge University Press, 2005.

Outlines of Scepticism. Translated and edited by Julia Annas \& Jonathan Barnes. New York: Cambridge University Press, 2010.

EVA, L. A. A. O Primeiro Cético (Acerca da Coerência do Pirronismo). In: SILVA FILHO, W. J. (Org.) O Ceticismo e a Possibilidade da Filosofia. Ijuí: Editora Unijuí, 2005. pp. 45-86. 
FAUR, J. La Teoría del Conocimiento de francisco Sánchez y el Verum/Factum de Vico. Cuadernos sobre Vico 4, 1994. pp. 83-99.

FERNÁNDEZ, M. G. El escepticismo en el Ocaso del renacimiento: La Duda, Signo de los Tiempos. AGORA. Papeles de Filosofía, no 4, 1984. pp.143-161.

FLORIDI, L. Sextus Empiricus: The Transmission and Recovery of Pyrrhonism. New York: Oxford University Press, 2002.

FREDE, M. Essays in Ancient Philosophy. Oxford: Oxford University Press, 1987.

FREDE, M \& STRIKER, G. (eds.) Rationality in Greek Thought. Oxford: Clarendon Press, 1996.

GERKRATH, L. Franz Sanchez - Ein Beitrag zur Geschichte der philosophischen Bewegungen im Anfänge der neuren Zeit. Vienna: Wilhelm Braumüller, 1860.

GILBERT .N. W. Renaissance Concepts of Method. New York: Columbia University Press, 1960.

GRECO, J. (ed.). The Oxford Handbook of Skepticism. New York: Oxford University Press, 2008.

HANKINS, J. (ed.) The Cambridge Companion to Renaissance Philosophy. Cambridge: cambridge University Press, 2007.

HANKINSON, R. J. The Skeptics. New York: Routledge, 1995.

INWOOD, B \& MANSFELD, J. (eds.) Assent and Argument: Studies in Cicero's Academic Books. Leiden/New York/Köln: Brill, 1997.

IRIARTE, J. Kartesischer oder Sanchezischer Zweifel? Bottrop:Wilhelm Postberg, 1935.

Francisco Sanchez, el Escéptico disfarzado de Carneades en discusión epistolar con Cristóbal Clavio. Un autógrafo inédito y una revalorización de su doctrina. In: Gregorianum. Vol. 21, No 2/4, 1940. pp. 413 451.

JIMÉNEZ, R. V. O. La teoria de la Causalidad Natural de Francisco Sánchez el Escéptico. In: Anales del Seminario de historia de la Filosofia. $\mathrm{n}^{\circ}$ 20, 2003. pp. 247-267.

Francisco Sánches, El Escéptico: Breve Historia de un Filósofo Desenfocado. Fundación Ignacio Larramendi. Madrid, 2012. 
JIMÉNEZ, A. M. Rhetoric, Dialectic, and Literature in the Work of Francisco Sánchez, El Brocense. In: Rhetorica: A Journal of the History of Rhetoric, Vol. 13, No. 1 (Winter 1995). pp. 43-59.

LAÊRTIOS, D. Vidas e Doutrinas dos Filósofos Ilustres. Brasília: UNB, 1987.

LASTRA, A. Francisco Sánchez y Sir Thomas Browne: De la Devoción y la Duda. Revista de Filosofia, ${ }^{\circ}$ 6, 1993. pp. 69-77.

LÈVY, C. Cicero Academicus - recherches sur les acadèmiques et sur la philosophie cicéronienne. Roma: École française de Rome, 1992.

LIMBRICK, E. Franciscus Sanchez Scepticus - Un Médecin Philosophe Précurseur de Descartes (1550-1623). In: Renaissance et Reforme, vol. 18, $\mathrm{n}^{\mathbf{o}} 4$, 1982. pp. 264-272.

LONG, A. A. From Epicurus to Epictetus: Studies in Hellenistic and Roman Philosophy. Oxford: Oxford University Press, 2005.

LONG, A. A. \& SEDLEY, D. N. The Hellenistic Philosophers - vol. 1 e 2. Cambridge: Cambridge University Press, 1987.

LOW, P. Declaração de Cambridge sobre a Consciência em Animais Humanos e não Humanos. Disponível em: <http://www.ihu.unisinos.br/noticias/511936declaracao-de-cambridge-sobre-a-consciencia-em-animais-humanos-e-naohumanos>. Acesso em: 23 de Agosto de 2014.

LUPOLI, A. Humanus Animus Nusquam Consistit: Doctor Sanchez's Diagnosiz of the incurable Human unrest and Ignorance. In: PAGANINI. G. \& MAIA NETO, J. R. (ed.) Renaissance Scepticisms. Dordrecht: Springer, 2009. pp. 149182.

MACLEAN, I. The "Sceptical Crisis" Reconsidered: Galen, Rational Medicine and the Libertas Philosophandi. In: Early Science and Medicine, Vol. 11, No. 3 2006. pp. 247-274.

MAIA NETO, J. R. Academic Skepticism in Early Modern Philosophy. In: Journal of the History of Ideas, vol. 58, n. 2, Abril/1997. pp.199-220.

MAIA NETO, J. R. , PAGANINI, G. \& LAURSEN, J. C. (eds.) Skepticism in the Modern Age - building on the work of Richard Popkin. Leiden/ Boston: Brill. 2009.

MAIA NETO, J. R. \& POPKIN, R. (eds.) Skepticism in Renaissance and PostRenaissance Thought: New Interpretations. Amherst, New York: Humanity Books, 2004.

MARCONDES, D. Ceticismo, Filosofia Cética e Linguagem. In: SILVA FILHO, W. J. (Org.) O Ceticismo e a Possibilidade da Filosofia. Ijuí: Editora Unijuí, 2005. pp.135-158. 
Rústicos X Urbanos: o Problema do Insulamento e a Possibilidade da Filosofia Cética. In: O Que Nos Faz Pensar, n 24, 2008. pp. 135-150.

Montaigne, a Descoberta do Novo Mundo e o Ceticismo Moderno. In: Kriterion: Belo Horizonte, no 126, Dez./2012, p. 421 - 433.

MARCOS, M. P. El Concepto de Ciencia en Francisco Sánchez. Salamanca, 1993.

MARTINS, M. Francisco Sanches era de Valença: Um testemunho seiscentista. In: Revista Portuguesa de Filosofia, T. 1, Fasc. 3, Jul. - Sep., 1945. pp. 281-285.

MONTEIRO, A. A. Francisco Sanchez e René Descartes. Coimbra, 1968.

MOREAU, J. Sanchez, Précartésian. In: Revue Philosophique de la France et de l'Étranger, T. 157, 1967. pp. 264-270.

Doute et Savoir chez Francisco Sanchez. In: Portugiesische Forschungen des Görresgesellschaft, erste Reihe, Aufsätze zur Portugiesischen Kulturgeschichte, vol. 1, 1960. pp.24-50.

MOREAU, P.-F. Le Scepticisme au XVIe et au XVIIe Siécle. Paris: Éditions Albin Michel, 2001.

MELIZZO, C. Nueva Introducciòn a Francisco Sanchez "El Esceptico". Zamora: Ediciones Monte Cassino, 1982.

MORAES FILHO, E. de Francisco Sanches na Renascença Portuguesa. Rio de Janeiro: Imprensa Nacional, 1953.

Francisco Sanches e a Dúvida Metódica na Renascença Portuguesa. Tese de doutorado. Rio de Janeiro: Ministério da Educação e Cultura, 1953.

NABAIS, J-M. A diáspora de Francisco Sanches na busca da Consciência do Eu. Cadernos de Estudos Sefarditas, n. ${ }^{\circ}$ 6, 2006. p. 357-368.

OLASO, E. de, Las Academica de Ciceron y la Filosofia Renascentista. In: International Studies in Philosophy 7, 1975. pp. 57-68.

OWEN, J. The Skeptics of the French Renaissance. London: Swan Sonnenschein, 1893.

PAGANINI, G. Skepsis: Le debat des Modernes sur le Scepticisme. Paris: Librairie Philosophique J. Vrin, 2008.

Montaigne, Sanchez et la Connaissance par Phénomènes. Les usages modernes d'un paradigme ancien. In: CARRAUD, V. \& MARION, J.-L. 
(eds.) Montaigne : scepticisme, métaphysique, théologie. Paris: Presses Universitaires de France, 2004. pp. 107-135.

Descartes and Renaissance Skepticism: The Sanches Case. In: MAIA NETO, J. R. , PAGANINI, G. \& LAURSEN, J. C. (eds.) Skepticism in the Modern Age - building on the work of Richard Popkin. Leiden/ Boston: Brill. 2009. pp. 249-268.

A Querela sobre o Ceticismo Antigo e Moderno: algumas reflexões sobre Descartes e seu contexto. In: Sképsis, ano IV, nº 7, 2011. pp. 88114.

PARKINSON, G. H. R. (ed.) The Renaissance and 17th Century Rationalism. London/ New York: Routledge, 2005.

PAGANINI. G. \& MAIA NETO, J. R. (ed.) Renaissance Scepticisms. Dordrecht: Springer, 2009.

PEREIRA, O. P. Rumo ao Ceticismo. São Paulo: UNESP, 2006.

PERIN, C. Descartes and the Legacy of Ancient Scepticism. In: BROUGHTON, J. \& CARRIERO, J. (Orgs.) A Companion to Descartes. Singapore: Blackwell Publishing, 2008. pp. 52-65.

PINTO, P. R. M. As Ideias Filosóficas de Francisco Sanches. Sképsis, ano III, ${ }^{\circ}$ 5, 2010. pp.103-148.

PINTO, S. da S. Francisco Sanches, Vida e Obra. Ed. Bracara Augusta, Braga, n. ${ }^{\circ} 28,1952$.

PLATÃO Ménon. Tradução de Maura Iglésias. São Paulo: Edições Loyola, 2001.

Fédon. Tradução de Jorge Paleikat e João Cruz Costa. In: Col. Os Pensadores. São Paulo: Abril Cultural, 1972.

PLUTARCH Reply to Colotes in Defence of the other Philosophers. pp. 153 317. In: Plutarch's Moralia. Vol. XIV. Cambridge: Harvard University Press, 1967.

Cimon and Lucullus. In: Plutarch's Lives. Vol. II. New York: The Macmillan Co, 1914. pp. 403 - 622.

POPKIN, R. História do Ceticismo de Erasmo a Spinoza. Tradução de Danilo Marcondes. Rio de Janeiro: Francisco Alves, 2000.

Ceticismo. Org.: EIGENHEER, E. M. Niterói: EDUF, 1986.

ROMÃo, R. B. Le Style Philosophique du Quod Nihil Scitur de Francisco Sanches. In: CURATOLO, B. \& POIRIER, J. (eds.) Le Style des Philosophes. 
Besançon-Dijon: Editions Universitaires de Dijon \& Presses Universitaires de Franche-Comté, 2007. pp. 37-43.

Quid? Estudos sobre Francisco Sanches. Porto: campo das Letras, 2003.

Juízo e Incerteza em Francisco Sanches. In: Revista Portuguesa de Filosofia, Vol. 66, fas. 1, 2010. pp. 51-62.

ROSS, W. D. (ed.) The Works of Aristotle. Vol. Oxford: Claredon Press, 1928.

SÁ, A. M. de Raízes e Projecção do Pensamento de Francisco Sanches. In: Revista Portuguesa de Filosofia, T. 11, Fasc. 3/4, Actas do I Congresso Nacional de Filosofia, Jul. - Dec., 1955. pp. 739-755.

Francisco Sanches.Lisboa: Edições SNI, 1948.

SNI, 1947.

Francisco Sanches, Filósofo e Matemático. 2 vols. Lisboa: edições

SANCHES, F. Obra Filosófica. Tradução de G. Manuppela, B. Vasconcelos, M. P. Meneses. Lisboa: Imprensa Nacional - Casa da Moeda, 1999.

2008 .

That Nothing is Known. New York: Cambridge University Press, Que Nada se Sabe. Madrid: Gil Blass, 1923.

Opera Philosophica. Nova Edição, introdução por Joaquim de Carvalho. Coimbra: Separata da Revista da Universidade de Coimbra, vol. XVIII, Imprensa de Coimbra, 1957.

SCHMITT, C. B. Cicero Scepticus: A Study of the Influence of the "Academica" in the Renaissance. The Hague: Martinus Nijhoff, 1972.

The Rediscovery of Ancient Scepticism in Modern Times. In: BUNYEAT, M. (ed.) The Skeptical Tradition. Berkley: University of California Press, 1983. pp. 225-252.

SCHMITT, C. B. , SKINNER, Q. , KESSLER, E. \& KRAYE, J. (eds.) The Cambridge History of Renaissance Philosophy. Cambridge: Cambridge University Press, 2008.

SEDLEY, D. The Motivation of Greek skepticism. In: BUNYEAT, M. F. (ed.) The Skeptical Tradition. Berkley: University of California Press, 1983. pp. 09-29.

SENCHET, E. J. M. Essai sur la Méthode de Francisco Sanchez. Paris: V. Giard \& E. Briere, 1904. 
SILVA, L. C. da Francisco Sanches nas correntes do pensamento renascentino. In: Revista Portuguesa de Filosofia, T. 39, Fasc. 3, Jul. - Sep., 1983. pp. 229-241.

Sanches au tournant de la pensée de la renaissance. Paris : Fond. Calouste Gulbenkian, Centre Culturel Portugais, 1984.

Actualidade de Francisco Sanches. In: Ensaios de Filosofia e Cultura Portuguesa (Braga, 1994). pp.91-98.

SINNOTT-ARMSTRONG, W. (ed.) Pyrrhonian Skepticism. New York: Oxford University Press, 2004.

STOUGH, C. Greek Skepticism: A Study in Epistemology. Berkeley/Los Angeles: University of California Press, 1969.

STRIKER, G. Essays on Hellenistic Epistemology and Ethics. Cambridge: Cambridge University Press, 1996.

Academics versus Pyrrhonists, reconsidered. In: BETT, R. (ed.)

The Cambridge Companion to Ancient Scepticism. Cambridge: Cambridge University Press, 2010. pp. 195 - 207.

TAVARES, S. Francisco Sanches e o Problema da Certeza. Actas del Primer Congreso Nacional de Filosofía, Mendoza, Argentina, marzo-abril 1949, tomo 3. pp. 2050 - 2056.

Francisco Sanches e a Crítica. Revista Portuguesa de Filosofia, T.

2, Fasc. 2 (Apr. - Jun., 1946), pp. 165-176.

A data de composição do "Quod nihil scitur". In: Revista Portuguesa de Filosofia, T. 1, Fasc. 4, Oct. - Dec., 1945. pp. 386-391.

Francisco Sanches e o problema da sua nacionalidade. In: Revista Portuguesa de Filosofia, T. 1, Fasc. 1, Jan. - Mar., 1945. pp. 63-76.

Ainda a naturalidade de Francisco Sanches. In: Revista Portuguesa de Filosofia, T. 1, Fasc. 2,Apr. - Jun., 1945. pp. 150-157.

THORSRUD, H. Ancient Scepticism. Stocksfield: Acumen, 2009.

VÁZQUEZ, M. I. B. La recuperación del escepticismo en el Renacimiento como propedéutica de la filosofía de Francisco Sánchez. Madrid: Fundación Universitaria Española, 2006.

La Recuperación de las Obras Escépticas em el Renascimento. In: Isagogé, Córdoba, 2005. pp. 67-73.

Intuiciones de criptojudaísmo en el Quod nihil scitur de Francisco Sánchez. In: Revista Internacional de Filosofía, vol. XIII, 2008. pp. 285-294. 
Escepticismo y medicina: la ópera medica de Francisco Sánchez. In: ARNAS, P. R. (Coord.) El Pensamiento Político em la Edad Media. Madrid: Fundación Ramón Areces, 2010. pp. 297 - 308.

Plato's and Aristotle's language critique in Francisco Sanchez's That Nothing is Known. In: Humanities 2012, 1(3), pp.192-204.

La evolución del escpeticismo académico desde Cicerón hasta su recupareación em el Renacimiento: la obra Cuestiones académicas. In: Ámbitos, $\mathrm{n}^{\circ} 28,2012$. pp. $39-50$.

YRJÖNSUURI, M. Self-knowledge and Renaissance Scpetics. In: SIHVOLA J. (ed.) Ancient Scepticism and the Sceptical Tradition. Helsinki : Philosophical Society of Finland, 2000. pp.225-253. 